Taigon Marques Gonçalves

\title{
Em defesa de uma solução inferencialista para o problema de seguir uma regra
}

\section{Tese de Doutorado}

Tese apresentada como requisito parcial para a obtenção do grau de Doutor pelo Programa de Pós-Graduação em Filosofia do Departamento de Filosofia do Centro de Teologia e Ciências Humanas da PUC-Rio.

Orientador: Prof. Dr. Ludovic Soutif 
Taigon Marques Gonçalves

\title{
Em defesa de uma solução inferencialista para o problema de seguir uma regra
}

\section{Tese de Doutorado}

Tese apresentada como requisito parcial para a obtenção do grau de Doutor pelo Programa de Pós-Graduação em Filosofia do Departamento de Filosofia do Centro de Teologia e Ciências Humanas da PUC-Rio.

\author{
Prof. Dr. Ludovic Soutif \\ Orientador \\ Departamento de Filosofia - PUC-Rio
}

Prof. Dr. Luiz Carlos Pinheiro Dias Pereira

Departamento de Filosofia - PUC-Rio

Dr. Carlos Mario Márquez Sosa Departamento de Filosofia - USP

Prof. Dr. Marcos Antônio da Silva Filho Departamento de Filosofia - UFPE

Prof. Dr. Edgar da Rocha Marques

Departamento de Filosofia - UERJ

Rio de Janeiro, 21 de setembro de 2021 
Todos os direitos reservados. É proibida a reprodução total ou parcial do trabalho sem autorização da universidade, do autor e do orientador.

Taigon Marques Gonçalves

Ficha Catalográfica

Gonçalves, Taigon Marques

Em defesa de uma solução inferencialista para o problema de seguir uma regra / Taigon Marques Gonçalves ; orientador: Ludovic Soutif. -2021.

$169 \mathrm{f} . ; 30 \mathrm{~cm}$

Tese (doutorado)-Pontifícia Universidade Católica do Rio de Janeiro, Departamento de Filosofia, 2021.

Inclui bibliografia

1. Filosofia - Teses. 2. Seguir uma regra. 3. Inferencialismo. 4. Teoria do significado. I. Soutif, Ludovic. II. Pontificia Universidade Católica do Rio de Janeiro. Departamento de Filosofia. III. Título. 
A todos os profissionais da ciência e da pesquisa que trabalharam e trabalham incessantemente para nos livrar do flagelo que é a atual pandemia 


\section{Agradecimentos}

Agradeço em primeiro lugar aos meus pais e a minha irmã, a quem devo tudo que sou e as coisas mais importantes que eu tenho.

Agradeço à Ana Karla, pelo amor, carinho, atenção, paciência e companheirismo e incentivo, especialmente nos momentos difíceis pelos quais passei.

Agradeço ao professor Ludovic Soutif, pela orientação diligente, estimulante e atenciosa que tive.

Agradeço ao professores Luiz Carlos e Jean-Baptiste Joinet, pela oportunidade que me deram de participar do programa de doutorado-sanduíche CAPES-Cofecub, e pela atenção e paciência que tiveram comigo durante todo o processo.

Agradeço aos meus amigos e colegas German, Carlota e Pedro Fior, pelas conversas, atenção, críticas e sugestões ao longo desses quatro anos.

Agradeço aos amigos de Lyon, Wendy e Yannis pela acolhida afetuosa durante o período de bolsa-sanduíche, e pelo aprendizado e amadurecimento que pude ter ao longo do nosso seminário de lógica, linguagem e computação.

Agradeço aos membros da banca, pela disponibilidade em avaliar meu trabalho, pelos comentários interessantes e críticas desafiadoras.

Finalmente, agradeço ao CNPq e à CAPES pelo apoio financeiro dado a esta pesquisa de doutorado.

"O presente trabalho foi realizado com apoio da Coordenação de Aperfeiçoamento de Pessoal de Nível Superior - Brasil (CAPES) - Código de Financiamento 001 


\section{Resumo}

Gonçalves, Taigon Marques; Soutif, Ludovic (orientador). Em defesa de uma solução inferencialista para o problema de seguir uma regra. Rio de Janeiro, 2021. 169 p. Tese de Doutorado - Departamento de Filosofia, Pontifícia Universidade Católica do Rio de Janeiro.

Esta tese tem por objetivo apresentar, analisar e defender uma solução inferencialista para o assim chamado problema de seguir uma regra. $\mathrm{O}$ primeiro capítulo serve como uma introdução. No segundo capítulo, traço as linhas gerais que balizam a discussão ao longo do resto do trabalho: introduzo a ideia de uma teoria do significado e os seus elementos e mostro que ela pode ser uma base sistemática para discussões metafísicas e epistemológicas - com destaque para os temas do realismo e do representacionismo. No terceiro capítulo, abordo em detalhes o problema de seguir uma regra - apresentando uma reconstrução do argumento do Wittgenstein de Kripke (baseando-me em Hattigandi) que conduz à conclusão cética- bem como analiso a viabilidade das possíveis linhas de resposta. No quarto capítulo, apresento o maquinário teórico-conceitual do inferencialismo (baseando-me sobretudo na obra de Brandom); esboço a estrutura geral de uma teoria semântica inferencialista combinando o inferencialismo com duas outras ideias: o normativismo pragmático e o expressivismo lógico. Por fim, no quinto capítulo, enfrento o problema cético de seguir uma regra a partir da perspectiva apresentada no capítulo anterior, e utilizando os elementos introduzido nos outros três capítulos.

Palavras-chave: seguir uma regra; inferencialismo; teoria do significado 


\section{Abstract}

Gonçalves, Taigon Marques; Soutif, Ludovic (advisor). In defense of an inferentialist solution to the rule-following problem. Rio de Janeiro, 2021. 169 p. Tese de Doutorado - Departamento de Filosofia, Pontifícia Universidade Católica do Rio de Janeiro.

In this dissertation I aim to present, analyze, and defend an inferentialist solution to the so-called rule-following problem. The first chapter works as an introduction. The second chapter sets the stage for the discussion throughout the dissertation. After introducing the very idea of a theory of meaning, I show that it can serve as a systematic basis for metaphysical and epistemological discussions wherein the themes of realism and representationalism take center stage. In the third chapter, I tackle the rule-following problem. More precisely, drawing on Hattiangadi's seminal interpretation, I offer a reconstruction of Kripkenstein's argument leading to the skeptical solution. I also assess the plausibility of the main lines of response to the problem. In the fourth chapter, I introduce the inferentialist theoretical-conceptual machinery inspired by Brandom, drawing the general framework for an inferentialist semantic theory that combines semantic inferentialism with pragmatic normativism and logical expressivism. The final chapter tackles the rule-following problem from the perspective set out in the previous chapter, using at the same time elements brought into play in the other three chapters.

Keywords: rule-following problem; inferentialism; theory of meaning 


\section{Sumário}

1. Introdução

2. Teorias do significado: linguagem, pensamento e realidade 14

2.1. Compromissos metodológicos: por que a linguagem importa 14

2.2. Teorias do significado 21

2.2.1. Teoria semântica 23

2.2.2 Elementos estruturais de uma teoria semântica clássica 24

$\begin{array}{ll}2.2 .3 \text { Extensionalismo clássico } & 37\end{array}$

2.2.4. Intensionalismo clássico I: mundos possíveis 45

2.2.5. Intensionalismo clássico II: realismo proposicional 49

2.3. Realismo, verdade e teorias do significado 50

2.3.1. Realismo e suas marcas $\quad 51$

2.3.2 Objetividade da verdade, ceticismo e teoria semântica 54

2.3.3 Objetividade da verdade, teorias clássicas e representacionismo 57

3. O problema de seguir uma regra 60

3.1. Teoria fundacional do significado e ceticismo semântico 60

3.2. O desafio cético 63

3.3. Realismo semântico e objetividade do significado 65

3.4. Internalismo psicológico, regressão ao infinito e intencionalidade 68

3.5. Disposicionalismo, normatividade e o problema do erro 71

3.6. Primitivismo 75

3.7. O argumento cético reconstruído: falácia naturalista, o problema da "estranheza" (queerness) e o paradoxo cético 78

3.7.1. Falácia naturalista 80

3.7.2. A "estranheza" (queerness) 82

3.7.3. O paradoxo cético $\quad 84$ 
3.9. Hattiangadi e a relatividade a normas 93

4. O quadro de uma teoria inferencialista do significado 97

4.1. Inferências e inferencialismo 97

4.2. Teoria da prática, pragmática e semântica 105

4.2.1. Registro de pontos e jogo das fichas coloridas

4.2.2. Da teoria da prática à pragmática normativa e à semântica inferencial

107

4.3. Transições inferenciais básicas 112

4.3.1. Transições linguagem-linguagem 113

4.3.2. Transições linguagem-entrada 113

4.3.3. Transições linguagem-saída: ações e intenções 116

4.4. Operadores lógicos, predicados e termos singulares: da lógica proposicional à lógica de predicados 119

4.4.1. Substituição: expressões substituídas-por, substituídas-em e estruturas substitucionais 124

4.4.2. Deduções expressivas 128

4.5. Vocabulário intencional: da semântica inferencial à representação

4.5.1. Atribuições de dicto e de re 131

4.5.2. Verdade 134

5. Fundações do significado no inferencialismo e a resposta ao cético 136

5.1. Intencionalidade e normatividade 136

5.1.1. A postura (stance) intencional 137

5.1.2. Tipos de intencionalidade 140

5.1.3. Implícito e explícito 141

5.1.4. Três níveis da normatividade de uma prática 143

5.1.5. A escada da intencionalidade 145

5.1.6. Intencionalidade original e equilíbrio interpretativo 146

5.2. Ceticismo semântico e o inferencialismo 148

5.3. A normatividade no mundo natural 149

5.3.1. Superveniência do normativo ao natural 151 
6. Conclusão

7. Referências bibliográficas 


\section{Introdução}

Uma das questões importantes na semântica filosófica diz respeito à fundação da significação linguística: em virtude de quais fatos as expressões linguísticas versam sobre coisas específicas no mundo? Qualquer que seja a teoria do significado que alguém possa vir a defender, uma tal teoria deve assumir que uma expressão linguística tem os atributos semânticos que ela tem em função de certos fatos. Tais fatos explicam por que- por exemplo - meu proferimento de "A grama é verde" quer dizer o que ele quer dizer, ao invés de ser um mero ruído ou querer dizer outra coisa. Normalmente, as respostas a essa questão envolvem um apelo a estados mentais internos e comportamentos dos sujeitos usuários da linguagem.

Ocorre que Kripke, inspirando-se em Wittgenstein, elaborou uma poderosa argumentação contra a própria ideia de que existem tais fatos sobre a significação linguística. Essa nova forma de ceticismo é no mínimo tão desconfortável e angustiante quanto as formas mais tradicionais, ao mesmo tempo em que levanta uma devida suspeita de ser autorrefutada, ao contradizer a si própria. Porque Wittgenstein originalmente havia abordado o tema utilizando situações de seguimento de regras, o problema ficou conhecido como "problema de seguir uma regra”. É digno de registro, entretanto, que esse é um epíteto um tanto quanto enganador para o problema, pois o problema e o paradoxo céticos podem ser formulados com clareza sem qualquer menção à noção de regra.

Por outro lado, a mesma noção de regra é frequentemente trazida - a começar pelo próprio Wittgenstein, de maneira alusiva - em algumas das respostas à questão. $\mathrm{Na}$ presente tese, pretendo apresentar e analisar uma resposta ao problema a ser oferecida a partir de uma teoria inferencialista do significado baseando-me principalmente, mas não exclusivamente - nos desenvolvimentos dessa perspectiva realizados nas últimas décadas por Robert Brandom. O 
inferencialismo de Pittsburgh (aqui normalmente chamado simplesmente de "inferencialismo") defende que a significação linguística é intrinsecamente normativa, e que os atributos semânticos inferenciais das expressões possuem prioridade explicativa sobre os atributos semânticos representacionais (referência e verdade). Um ponto geral então é que tomar regras ou normas constitutivas das relações inferenciais entre expressões como o ponto de partida de uma teoria do significado nos dá alguma vantagem ao buscarmos uma resposta para o problema em comparação com a estratégia representacionista, adotada pelas teorias semânticas ortodoxas.

No próximo capítulo, estabeleço as linhas gerais da abordagem tomada no restante deste trabalho. Começo fazendo uma defesa da primazia metodológica da filosofia da linguagem em relação ao restante da filosofia. Recupero ali, baseandome no Tractatus, a distinção entre forma gramatical e forma lógica e a correspondência um a um entre fatos, pensamentos e enunciados em uma linguagem alçada ao status de característica universal. Em seguida, introduzo e exploro em detalhes a noção de uma teoria do significado, que se desdobra em teoria semântica e teoria fundacional do significado; mostro como discussões clássicas de metafísica e epistemologia estão intrinsecamente conectadas com questões a respeito da estrutura de uma teoria semântica - sobre os atributos semânticos que as expressões linguísticas devem possuir.

No terceiro capítulo, apresento em pormenores o problema de seguir uma regra enquanto um problema para a teoria fundacional do significado e para a própria intencionalidade em geral. A reconstrução da argumentação cética do texto de Kripke é feita com fulcro nas elucidações realizadas por Hattiangadi em Oughts and Thoughts. Mostro ali - utilizando o aparato técnico-conceitual introduzido no segundo capítulo - como o argumento cético levaria, sob toda e qualquer circunstância, a uma contradição. Identifico as premissas em jogo no argumento, e avalio quais delas poderiam ou não ser abandonadas a fim de evitar o paradoxo. Sustento também que a assim chamada solução cética, sob virtualmente qualquer interpretação, fracassa em escapar do próprio ceticismo semântico.

O quarto capítulo apresenta e explora as principais ideias do tipo de inferencialismo esboçado primeiramente por Sellars e desenvolvido sistematicamente depois por Brandom. O inferencialismo de Pittsburgh se diferencia de outras possíveis versões porque ele traz, para além da noção de que 
inferências são constitutivas da significação, dois outros princípios: o normativismo pragmático e o expressivismo lógico. Explico então como os três princípios inferencialismo semântico, normativismo pragmático e expressivismo lógico - se combinam para a construção de uma teoria semântica, com o auxílio de um experimento mental baseado no jogo dos registradores de Brandom. Por fim, introduzo expressões-chave do vocabulário representacional ("ser sobre" e "verdade") na semântica inferencialista por meio de deduções expressivas. Esse capítulo nos dá assim uma ideia geral de como uma teoria semântica inferencialista deveria funcionar.

No quinto e último capítulo, enfrento o problema de seguir uma regra utilizando o maquinário teórico-conceitual inferencialista apresentado anteriormente. Recorro ao normativismo pragmático como a base do inferencialismo, agora no âmbito de uma teoria fundacional do significado. A maior dificuldade neste ponto é explicar como a existência de um domínio normativo pode ao mesmo tempo ser irredutível e compatível com a existência de um domínio natural. Em outras palavras, como a nossa visão naturalista de mundo pode admitir a existência de regras, que não podem ser elas próprias inteiramente descritas em termos das ciências naturais? Defendo, nesse ponto, a atitude conciliatória adotada por Sellars e Brandom, trazendo à baila para isso o conceito de superveniência. Encerro o capítulo tecendo algumas considerações a respeito de qual seria a forma lógica de expressões como "querer dizer" (utilizadas na formulação do problema de seguir uma regra) a partir da perspectiva inferencialista. 


\section{Teorias do significado: linguagem, pensamento realidade}

\section{1 Compromissos metodológicos: por que a linguagem importa}

Quero expressar meus compromissos metodológicos logo de início. Este trabalho se insere (ou pretende se inserir) numa tradição que reivindica a filosofia da linguagem como "filosofia primeira", i.e., como o ponto de partida mais adequado para abordar as questões filosóficas em geral. Mas esta posição está longe de ser uma posição óbvia. A filosofia trata das coisas mais gerais e abstratas da realidade, e da nossa relação, enquanto seres inteligentes e sensientes, com essa realidade. Sendo assim, pelo menos aparentemente o estudo da linguagem não se sobressai como algo filosoficamente muito importante - pelo menos não tanto quanto o estudo das categorias fundamentais da realidade ou da natureza do conhecimento, em especial. Isso explica por que, ao longo de mais de dois mil anos, esse status de "filosofia primeira" foi reservado ora à metafísica, ora à epistemologia. Somente muito recentemente tal status foi concedido à filosofia da linguagem, por obra dos primeiros filósofos analíticos, que operaram a chamada "virada linguística". 1

Não muitas vezes, entretanto, os autores se viram compelidos a justificar de modo mais articulado e sistemático porque eles passaram a dar tão grande relevância filosófica ao estudo da linguagem. Ainda, os autores que defenderam manifestamente a primazia da linguagem o fizeram por colocações sucintas, excessivamente restritivas e que terminavam por soar até arbitrárias. ${ }^{2}$ Isso ajuda a

\footnotetext{
${ }^{1}$ Embora o interesse pela linguagem e pelos seus aspectos semânticos não fosse tão frequente antes da filosofia analítica, autores, canônicos como Platão, Aristóteles e Locke deram à essa temática um lugar de destaque em suas obras. Eles podem ser vistos como tendo desenvolvido teorias mais ou menos sistemáticas a respeito da significação linguística, e embora, obviamente, não tenham feito dessas teorias o ponto de partida de seus sistemas filosóficos.

${ }^{2}$ Dois exemplos paradigmáticos a esse respeito são o $2^{\circ}$ Wittgenstein e Dummett. O $2^{\circ}$ Wittgenstein reiteradas vezes sustentou que a (boa) filosofia consistia inteiramente na análise pragmática da linguagem, isto é, na explicitação dos contextos de uso de palavras para conceitos fílosoficamente
} 
explicar por que hoje em dia há entre os autores analíticos uma tendência de rejeitar a filosofia da linguagem o status de "filosofia primeira" e mesmo se refiram com certo desdém à ideia de uma "virada linguísitca" (cf. WILLIAMSON, 2007, cap. $1)$.

De qualquer modo, acredito serem identificáveis na tradição analítica dois grandes argumentos em favor da primazia metodológica da filosofia da linguagem: um mais modesto e outro bem mais ambicioso. Da maneira como eu os compreendo, eles não nos levam a colapsar a filosofia com a análise da linguagem ou com a análise conceitual através da linguagem, nem descartam de antemão a importância de todo e qualquer conteúdo empírico de outras ciências para a atividade filosófica.

$\mathrm{O}$ argumento mais modesto remonta à obra de Quine, e gira, sobretudo em torno daquilo que ele chamou de ascensão semântica:

A estratégia da ascensão semântica é levar a discussão para um domínio no qual ambos os partidos concordam melhor quanto aos objetos (a saber, palavras) e quanto aos termos principais que lhes dizem respeito. As palavras, ou as inscrições, ao contrário de pontos, milhas, classes, e o resto, são objetos tangíveis da dimensão tão popular na vida pública, na qual homens com esquemas conceptuais distintos comunicam no seu melhor. A estratégia é ascender a uma parte comum de dois esquemas fundamentalmente díspares, para melhor discutir as fundações díspares. Não admire que seja uma ajuda na filosofia. (QUINE, 2010a, pp. 338-339)

Ou seja, o ponto consiste em os filósofos expressarem e discutirem suas posições falando de uma maneira filosoficamente "agnóstica" - no caso, falando sobre expressões linguísticas (sentenças, palavras etc.), ao invés de falar das coisas ou do nosso pensamento sobre elas. As diferenças entre posições substantivas sobre o mundo são expressas em diferenças na atribuição de certas características às expressões linguísticas. Isso permite, por exemplo, que um nominalista dos universais possa reconhecer a posição do realista como inteligível sem entrar em contradição consigo mesmo (ele pode falar que unicórnios são animais sem pressupor que unicórnios existem, ao dizer que não há nada que satisfaça o predicado "ser um unicórnio", e ao mesmo tempo, dizer que se algo é um unicórnio,

problemáticos (cf. Investigações Filosóficas, §116). Uma vez que as articulações conceituais seriam reveladas no uso padrão das palavras em situações práticas de comunicação e interação, os problemas filosóficos seriam inteiramente "dissolvidos" (cf. Investigações Filosóficas, §§122-126). Dummett criticou a resistência do $2^{\circ}$ Wittgenstein em relação à construção de sistemas gerais e abstratos em filosofia, mas, ecoando Frege e o $1^{\circ}$ Wittgenstein, insistiu que "o objetivo da filosofia é a análise do pensamento" (p. 458, 1978). Entretanto, em ambos os casos, e felizmente, as opiniões filosóficas "substantivas" muitas vezes parecem não refletir concepções metafilosóficas tão restritas. 
então é um animal). (cf. QUINE, 2010b, cap 1)

$\mathrm{O}$ argumento mais ambicioso para conceder primazia metodológica à filosofia da linguagem pode ser encontrado de maneira mais ou menos implícita no Tractatus (TLP) de Wittgenstein. Sua conclusão é mais ambiciosa na medida em que o argumento envolve ideias filosoficamente substantivas e tem um sabor transcendental. Ele pode ser sucinta e informalmente estruturado da seguinte maneira

(1) Se A representa B (de maneira articulada), então A e B tem uma forma ou estrutura em comum;

(2) Pensamentos representam fatos (da realidade)

(3) Enunciados representam pensamentos;

de 1,2 e 3 inferimos

(4) Enunciados representam fatos (da realidade);

e de 1 e (4) inferimos

(5) Enunciados e fatos (da realidade) possuem uma forma ou estrutura em comum.

A premissa (1) contém o insight básico que ficou conhecido na literatura filosófica como teoria pictória, que pode ser explicado resumido através de um exemplo. Consideremos a relação entre a extensão territorial do América do Sul e um mapa da América do Sul: o mapa só representa o continente se eles são estruturalmente semelhantes em pelo menos alguns aspectos. Há uma maneira de desenhar e interpretar mapas tal que a relação espacial entre duas marcações no mapa e a relação entre duas coisas reais que são representadas por essas marcações devem ser mais ou menos congruentes. Supondo que seja um mapa físico, entre outras coisas o deserto do Atacama deve ser localizado à direita do oceano pacífico e imediatamente à esquerda da cordilheira dos Andes. A congruência entre o mapa $\mathrm{e}$ o continente poderia ser atestada talvez por alguém fazendo um voo suborbital observando o continente (ou parte dele) pela janela do seu veículo ao mesmo tempo em que vê o mapa em suas mãos, posicionando-o de um modo que as duas imagens sejam congruentes. Nesse caso, Wittgenstein diria que a forma da afiguração é a forma espacial (cf. TLP 2.1-2.25, 4.011, 4.013-4.016).

A ideia por trás de (1) poderia ser considerada como um truísmo "tácito", 
algo que qualquer um poderia aceitar, mas apenas que ninguém com tino filosófico se daria conta. As premissas (2) e (3), por outro lado, são truísmos manifestos. Enquanto seres inteligentes, nós somos capazes de representar como as coisas estão (ou podem estar) na realidade; tais representações são estados mentais que, seja lá qual for a natureza específica, são chamados pensamentos. E o conteúdo representacional desses estados é expresso e comunicado através do uso significativo da linguagem: crenças, os pensamentos que podem ser verdadeiros ou falsos, são paradigmaticamente expressos por sentenças declarativas (enunciados), que igualmente são passíveis de serem verdadeiras ou falsas ((4)) (cf. TLP 3.1, 3.11, $3.12,3.2,3.22,4,4.05,4.06)$.

A conclusão é que, se nós somos de fato capazes de representar a realidade através de pensamentos - se nós representamos a nós mesmos coisas no mundo e possíveis fatos envolvendo essas coisas, e se, além disso, a linguagem expressa (representa) o pensamento, então a linguagem, o pensamento e a realidade compartilham uma mesma forma ou estrutura! Wittgenstein chamou essa forma ou estrutura que a realidade, o pensamento e a linguagem possuem em comum de forma lógica.

Essa forma lógica que o Wittgenstein do Tractatus atribui à linguagem não é, entretanto, expressa pelas gramáticas das nossas linguagens naturais. A forma lógica da linguagem (proposicionalmente articulada) jaz em uma estrutura profunda, necessariamente compartilhada por toda e qualquer linguagem atual ou possível, e ela deve ser expressa por uma gramática lógica especial - algo como uma linguagem universal dos conceitos (characteristica universalis) proposta séculos antes por Leibniz.

Poderíamos, então, analisar ou traduzir qualquer sentença da linguagem natural usada significativamente em termos de sentenças de uma linguagem simbólica artificial elevada ao status de característica universal. Na gramática dessa característica universal, as categorias sintáticas expressariam graficamente os atributos lógico-semânticos do seu vocabulário. As regras de formação das sentenças explicitariam as regras de formação do pensamento (representacional), e, dada a natureza pictórica do pensamento, explicitariam a estrutura última da própria realidade. Além disso, as regras de inferência dessa linguagem explicitariam o modo correto de se raciocinar, o que, novamente à luz do isomorfismo entre pensamento e realidade, significa que elas explicitariam o modo objetivamente 
correto de se raciocinar. Como resultado desse método, teríamos finalmente alcançado um modo de abordar as questões filosóficas com absoluta clareza; um modo de fazer filosofia que evitasse as confusões conceituais desnecessárias aos quais os filósofos são induzidos, quando se expressam com a linguagem ordinária e tomam a forma gramatical da linguagem ordinária como sendo a sua forma lógica.

A primazia metodológica da linguagem que o argumento estabelece vem, naturalmente, acompanhada de um antipsicologismo. Considerando que todo conteúdo representacional do pensamento é manifesto na nossa linguagem, uma investigação metafísica a respeito da estrutura da realidade pode prescindir de uma investigação a respeito da natureza dos processos psíquicos envolvidos na atividade de pensar, de representar a realidade (cf. KENNY, 1973;2006, pp. 47-48).

Esse antipsicologismo é, entretanto, também metodológico, e não ontológico. Ele não exige que se abdique prima facie da tese de que a nossa capacidade de pensar antecede o aprendizado de uma linguagem pública. Nem mesmo impede que se adote uma posição fenomenalista em metafísica - isto é, a posição de que a própria realidade é constituída apenas de dados sensoriais (cf. AYER, 1936;1952 cap. 7). Mas ele nos preclui, por exemplo, de assumir de saída que a lógica tenha alguma coisa a ver com aspectos peculiares da atividade de pensar. $^{3}$

Agora, o que acabamos de fazer aqui foi apenas apresentar um esboço meio informal dos argumentos. Reconheço que uma apresentação convincente sobretudo do argumento "forte" do $1^{\circ}$ Wittgenstein - exigiria um denso e longo escrutínio de cada um dos seus passos. No entanto, tal coisa nos levaria muito além do escopo deste trabalho. De qualquer maneira, o que é defendido aqui, e da maneira como é defendido, pressupõe o endosso de ambas as conclusões. Assim, tomo como meus os compromissos programáticos e metodológicos que essas conclusões estabelecem.

Essa atitude de endosso simultâneo dos dois argumentos e suas conclusões pode parecer estranha. Tendo em vista as enormes diferenças de perspectivas filosóficas entre o Quine de meia idade e o jovem Wittgenstein, é certo que cada um rejeitaria o argumento do outro. Os argumentos são incompatíveis se colocados dentro do contexto teórico de cada um dos autores. Quando colocados em seus

\footnotetext{
${ }^{3}$ Tal tipo de atitude foi assumida explicitamente por, por exemplo J. S. Mill e aparece como pano de fundo para vários autores canônicos (Hume, por exemplo).
} 
respectivos contextos histórico-filosóficos, os dois argumentos em favor da primazia metodológica da filosofia da linguagem parecem ter, em realidade, consequências opostas.

Em primeiro lugar, a conclusão do argumento "forte" pela primazia metodológica da linguagem é usada ela própria numa cadeia argumentativa maior que estabelece a impugnação de conteúdo cognitivo a qualquer posição metafísica - incluindo as expressas dentro da própria obra (TLP 6.53-7). Mas, como vimos, o ponto de Quine em favor da ascensão semântica ia ao sentido oposto, de tentar restaurar o conteúdo cognitivo das alegações metafísicas. Para o Wittgenstein do Tractatus, a filosofia começa e termina com a filosofia da linguagem. Para Quine, por outro lado, a filosofia da linguagem é só um começo.

Em segundo lugar, o uso que os autores fazem da lógica em sua relação com as linguagens naturais também tem propósitos antagônicos. Quine sustentou que as formas discursivas ordinárias são muitas vezes inapropriadas para se representar cientificamente o mundo, e que por isso a lógica que deve ser alçada ao status de característica universal não tem nenhum compromisso em oferecer paráfrases fiéis da linguagem natural. Pelo contrário, Quine sustentava que a lógica "escolhida" teria muitas vezes função corretiva em relação à linguagem ordinária, no sentido de considerar certos discursos como sendo científica e filosoficamente "espúrios" e deliberadamente não acomodá-los em sua gramática (cf. por exemplo, QUINE, 2010b, caps. 2 e 8). Penco denomina tal abordagem de reviosionista. (PENCO, 2006, p. 79) Em contraste, o Wittgenstein do Tractatus adota uma abordagem hermenêutica, ou seja, a ideia de que os discursos da linguagem ordinária são perfeitamente legítimos por si só e que a função do simbolismo lógico é a de explicitar sua forma lógica (ibidem, p.79). A lógica elevada ao status de característica universal deveria, portanto, reconhecer e acomodar totalmente as formas discursivas ordinárias. ${ }^{4}$

Em relação ao primeiro ponto, nos colocamos mais próximos da posição de

4 Reconhecer e acomodar todo o vocabulário da linguagem natural não é o mesmo que dizer que todo vocabulário tem função representacional. O Tractatus reconhece a "legitimidade" do discurso ético, estético, lógico-matemático e (com ressalvas) filosófico, mas nega peremptoriamente que esses discursos tenham conteúdo cognitivo ou representacional, ou que seus enunciados possam informar algo sobre o mundo (TLP 4.11, 4.12-4.1212, 6.1265-6.22, 6.2331, 6.31-6.372, 6.4-7). O Tractatus não propõe alterações na linguagem ordinária, nem nas linguagens científicas específicas, mas ele propõe alterações radicais em relação à visão que os filósofos costumavam adotar em relação a elas. 
Quine: como salientamos no parágrafo anterior, a ideia de que a filosofia consiste tão somente na análise da linguagem - seja ela lógico-semântica ou pragmática - é uma posição extremada e que com justiça é rejeitada pela maioria dos autores analíticos contemporâneos. Ademais, a aceitação da metafilosofia de Wittgenstein implicaria obviamente na própria inviabilidade do argumento da ascensão semântica.

Por outro lado, o presente trabalho assume a postura hermenêutica de Wittgenstein frente à linguagem ordinária. Queremos tomar como legítimas, e não como espúrias, as formas de discurso próprias das linguagens naturais. Tendo todas essas considerações em vista, julgo ter amenizado a tensão entre os dois argumentos em favor da primazia metodológica da filosofia da linguagem, e aberto a possibilidade de tratá-los como compatíveis entre si.

Duas últimas observações de cunho metodológico envolvendo a interface entre lógica e linguagem natural. A primeira é que, embora estejamos comprometidos com a ideia de que há uma lógica (ou uma "superlógica" que seja combinação entre diferentes sistemas) que funcione como característica universal para uma abordagem inferencialista, não vamos aqui nos ocupar em identificar que lógica é essa, nem mesmo quais seriam as melhores candidatas a realizar esse papel. No entanto, utilizo a lógica clássica (e as ditas lógicas "complementares", se for o caso) e seus atributos como paradigma em nossas discussões. Isso se justifica na medida em que, em alguns momentos, pode ser conveniente lançar mão de formalizações. Mas se justifica principalmente porque, em várias discussões, se faz necessário tomar por hipótese alguma lógica que conhecemos como sendo a genuína característica universal.

A segunda observação é que não devemos tratar essa "verdadeira" lógica (qualquer que seja ela) como sendo algo etéreo, transcendente, totalmente apartado do nosso modo de falar usual, e acessível apenas através de intuições quase místicas de lógicos e filósofos. A gramática de uma linguagem formal é definida a partir da linguagem natural, isto é, tomando uma linguagem natural como metalinguagem ${ }^{5} \mathrm{e}$ a linguagem formal como linguagem-objeto. Isso significa que a gramática (o vocabulário e a sintaxe) de uma linguagem formal é no final das contas um subconjunto próprio da gramática da linguagem natural. E nesse subconjunto, a

\footnotetext{
${ }^{5}$ Acrescida de alguns termos técnicos próprios das formais ciências.
} 
forma lógica das expressões é definida pela sua forma gramatical. Assim, o que de fato nós temos quando, por exemplo, o Wittgenstein do Tractatus fala em análise lógica da linguagem, é que nós tomamos um fragmento da linguagem comum como sendo explicativamente mais básico que todo o resto. O "corte" desse fragmento que é tomado como primitivo define qual lógica estamos usando.

Por uma questão de simplificação na forma de falar, chamamos no presente trabalho esse fragmento da linguagem natural que é tomado como sendo mais básico (qualquer que seja ele e que é expressivamente congruente à notação da lógica alçada ao status característica universal) de logiquês. Um enunciado dito em logiquês é uma paráfrase de uma sentença qualquer daquela língua que corresponda a uma forma de expressão corriqueira no "jargão" dos lógicos, que aproxime a estrutura de um enunciado expresso naquela língua da estrutura de uma sentença formalizada em uma lógica. Por exemplo, o enunciado "Todo homem é mortal” é traduzido do português para o logiquês como "Para qualquer objeto, se esse objeto é um homem, então ele é mortal”, aproximando-o estruturalmente a sua tradução em uma linguagem simbólica: $(\mathrm{x})(\mathrm{Fx} \rightarrow \mathrm{Gx})$.

\subsection{Teorias do significado}

A melhor maneira de levar a cabo os compromissos metodológicos e programáticos acima é por meio da elaboração do que tem sido chamado na literatura de teoria do significado. É por meio de teorias do significado que os filósofos pretendem dar uma explicação sistemática e articulada do tipo que estamos buscando. O uso que se tem feito dessa expressão na literatura filosófica, entretanto, não é unívoco, de maneira que, no sentido mais genérico e vago possível, qualquer filosofia da linguagem feita de maneira minimamente sistemática possa ser denominada como tal. Speaks ajuda a lançar luz sobre o assunto, ao apontar que há duas questões fundamentais distinguíveis às quais os filósofos respondem por meio da construção do que eles vêm chamando de "teoria do significado". Dada uma expressão linguística em uma linguagem qualquer utilizada por sujeitos, podemos perguntar: (i) qual é o significado dessa expressão? e (ii) em virtude de que fatos essa expressão linguística tem o significado que ela tem? Ao respondermos (i) estaríamos dando uma especificação do significado da expressão em questão, enquanto que ao respondermos (ii) estaríamos explicando como aquela expressão vem a ter o significado que ela tem (SPEAKS, 2020). Embora as duas 
questões sejam interdependentes entre si, e embora seja comum encontrar teorias do significado que tratem de responder ambas ao mesmo tempo, Speaks justifica essa distinção na medida em que se pode pretender responder uma questão sem que se pretenda responder à outra (ibidem). ${ }^{6}$

Para ilustrar o seu ponto, o autor compara a situação de um filósofo da linguagem com a situação de um antropólogo visitando uma tribo isolada com intuito de pesquisar sobre suas regras de etiqueta. De acordo com Speaks, o antropólogo pode ter dos tipos de interesse: ele pode querer uma especificação sistemática de quais são as regras de etiqueta que os membros daquela tribo seguem (por exemplo, se os velhos iniciam ou não as refeições antes dos mais jovens), quais são as categorias de comportamentos e como elas se relacionam entre si (se um jovem inicia a refeição antes do chefe familiar, então ele é classificado como um "blak", de modo que os blaks não devem participar das duas próximas refeições); mas o nosso antropólogo também pode, em vez disso, querer saber que tipos de fato sobre aquele grupo de nativos fazem com que ele seja governado por aquelas regras de etiqueta em particular, e não por outras regras - ou ainda, que tipos de fato fazem com que exista um sistema de regras de etiqueta, de um modo qualquer (por exemplo, a tribo pode considerar regra de etiqueta toda conduta de origem ancestral envolvendo atividades de alimentação, conversação e contato físico). Um antropólogo elaborar um manual especificando quais são as regras de etiqueta na tribo e como elas se relacionam entre si é, então, semelhante ao filósofo elaborar o que Speaks chama de teoria semântica. Por outro lado, o antropólogo fazer um trabalho a respeito de quais fatos transformam padrões de comportamentos em regras de etiqueta equivale a um filósofo formular o que Speaks denomina de teoria fundacional do significado (SPEAKS, 2020).

O restante desse capítulo pretende dar uma visão geral sobre teorias semânticas, colocando aspectos fundacionais em segundo plano. O capítulo 3 apresenta o problema de seguir uma regra como um problema para qualquer teoria

\footnotetext{
${ }^{6} \mathrm{O}$ caso de Wittgenstein é especialmente intrigante, na medida em que ele se ocupou profundamente de ambas as questões, mas em fases distintas da sua trajetória intelectual. O Tractatus representa a primeira tentativa sistemática de responder (i). Com o passar do tempo, entretanto, Wittgenstein abandonou a ideia de fornecer uma teoria que fornecesse sistematicamente o significado das expressões, mas passou a tematizar de forma tenaz sobre a questão (ii), o que culminou nas suas reflexões sobre seguir uma regra. Este trabalho é certamente tributário à contribuição de Wittgenstein para ambas as questões, e busca de certa maneira sintetizar as respostas que ele deu a elas.
} 
fundacional do significado. O capítulo 4 apresenta e discute o inferencialismo (como destacamos na introdução inferencialismo pragmático normativo esboçado por Sellars e desenvolvido em detalhes por Robert Brandom). O capítulo 5 tem como escopo o tratamento que uma teoria fundacional do significado na perspectiva inferencialista pode proporcionar a este problema, respondendo o desafio cético.

\subsubsection{Teoria semântica}

É patente que o fenômeno da significação linguística tem aspectos múltiplos, que podem ser arregimentados de diferentes maneiras. Em um corte horizontal, temos vários estratos da significação de acordo com o grau de complexidade estrutural das expressões linguísticas: frases, orações, sintagmas, palavras, e, em cada estrato, diferentes possibilidades de combinação entre diferentes tipos de categorias. A significação que é produzida pelo arranjo de palavras formando um sintagma é um tanto diferente da significação que é produzia pelo arranjo de sintagmas formando uma oração (os sintagmas tomados isoladamente, em geral, não são utilizados pelos sujeitos para comunicar algo, ao contrário das orações). Em um corte vertical, por outro lado, normalmente temos diferentes dimensões da significação em cada categoria que compõe tais estratos. Comparemos, por exemplo, o objeto a que um nome se refere, por um lado, com os efeitos que o seu proferimento pode gerar no comportamento de uma audiência. Temos ainda as diferentes relações nas diferentes dimensões da significação entre expressões de diferentes estratos: o modo como um nome contribui para a verdade ou falsidade de uma oração se distingue do modo como um advérbio de negação o faz. E expressões feitas com as mesmas partes tomadas isoladamente produzem significações inteiramente distintas em função da ordem em que se arranjam na expressão de estrato superior ("Maria ama Pedro" quer dizer algo bem diferente de “Pedro ama Maria”!). Temos aspectos semânticos e aspectos pragmáticos da significação das expressões, e temos relações entre eles (entre, por exemplo, o contexto de fala de uma oração e a sua verdade).

De tudo isso uma teoria semântica deve dar conta, e deve fazê-lo representando explicitamente esses aspectos por meio de uma lógica (isto é, de uma 
lógica alçada ao status de característica universal) ${ }^{7}$. O grande desafio, entretanto, é por onde começar. Isso significa perguntar qual (ou quais) dos inúmeros aspectos da significação deve ser tomado como básico em relação aos demais aspectos (qual dimensão da significação de qual estrato é tomada como básica?). A resposta para tal questão deve nortear, por um lado, a escolha dos elementos básicos do simbolismo lógico apropriado (em relação aos quais os demais serão definidos), e por outro, a escolha do fragmento da linguagem a ser tomado como expressivamente congruente a essa estrutura lógica básica. Em outras palavras, a estrutura da gramática lógica deve ter o mesmo poder expressivo que a gramática "válida" para o fragmento fundamental da linguagem natural - a gramática do "logiquês". Esta última dever ser, evidentemente, uma versão bem empobrecida da gramática real da linguagem natural.

A obra do Frege maduro (a partir da década de 1890) ofereceu um primeiro esboço de como construir uma teoria semântica. Poderíamos dizer, sem exageros, que ela balizou toda a filosofia da linguagem, de modo que suas linhas gerais foram como que tomadas como paradigma da semântica filosófica, além de seus insights terem influenciado também a abordagem de aspectos da pragmática. Por essa razão, denominamos aqui uma teoria semântica clássica qualquer teoria que tome as linhas gerais traçadas por Frege - apresentadas na próxima subseção - como sendo estruturantes.

\subsubsection{Elementos estruturais de uma teoria semântica clássica}

Frege definiu como atributo básico da significação de uma expressão o seu valor semântico (Bedeutung): a característica de uma expressão que determina se a as sentenças em que ela ocorre são verdadeiras ou falsas (MILLER, 2007, p. 11) ${ }^{8}$. No caso de um enunciado usado em sua forma padrão - para dizer que algo é ou não o caso - esse valor semântico é a sua verdade ou falsidade. No caso das expressões subsentenciais (podem ser tanto sintagmas quanto palavras e locuções), o valor semântico é aquilo pelo que ela está por (stand for) na realidade, aquilo a que ela

\footnotetext{
${ }^{7}$ Para uma concepção alternativa a respeito do desenvolvimento de uma teoria semântica baseada em uma ideia de modelo próprio das ciências naturais e não da lógica, ver "Semantics as ModelBased Science", de Seth Yalcin, in Ball \& Rabern, 2018 (cap. 12).

${ }^{8}$ Adotamos aqui a terminologia de Miller, que traduz o termo "Bedeutung" de Frege por valor semântico (semantic value).
} 
denota ou se refere.

No âmbito do simbolismo lógico, as categorias sintáticas básicas são definidas em termos do tipo de valor semântico que elas podem ter. Tais categorias sintáticas básicas são, grosso modo, as categorias do que hoje se denomina lógica clássica de primeira ordem. Sentenças (que traduzem apenas os enunciados (sentenças declarativas) da linguagem natural) têm como valor semântico valores de verdade (a verdade ou a falsidade). ${ }^{9}$ Expressões subsentenciais ${ }^{10}$ são divididas em três categorias: termos singulares, predicados e termos lógicos (operadores e quantificadores), e é na caracterização que ele oferece do valor semântico dessas categorias que reside talvez o maior insight de Frege para a lógica.

Frege explica o valor semântico dos termos subsentenciais em analogia com as funções matemáticas. Ele descreve uma função como um "algo" insaturado que, quando conjugado com um objeto (que é uma coisa completa por si só), "produz" outro objeto. Este último, o "produto", é chamado de valor, enquanto o objeto que é conjugado com a função é chamado de argumento. Funções são expressas tanto por termos funcionais quanto por conjuntos de ênuplas ordenadas (o termo funcional " $y=2 x+2$ " e o conjunto de ênuplas ordenadas $\{<0,2>,\langle 1,4>,<2,6>$, $<3,8>\ldots\}$, por exemplo, representam a mesma função: quando 0 é o argumento, 2 , é o valor; quando 1 é o argumento, 4 é o valor, e assim por diante). A ideia de Frege foi então tomar os valores semânticos de predicados e termos lógicos como um tipo especial de função, cujo produto da sua conjugação com um objeto é sempre um valor de verdade - verdadeiro ou falso (cf. FREGE, 2009, cap. 5; MILLER, 2007, pp.14-16). Consideremos, por exemplo, que o predicado " $F$ " seja equivalente ao termo funcional “( ) é um filósofo", e que "s" e "n" sejam equivalentes aos nomes "Sêneca" e "Nero", respectivamente. Se prefixarmos "s" com "F", então a sentença resultante "Fs" tem como valor de verdade o verdadeiro; mas se prefixarmos " $n$ " por " $F$ ", então a sentença resultante tem como valor o falso. Operadores lógicos

\footnotetext{
${ }^{9} \mathrm{O}$ paradigma notacional que tomamos aqui não é aquele de Frege, mas aquele que foi desenvolvido posteriormente a partir dos Principia Mathematica de Russell e Whitehead. Na notação original de Frege, as sentenças da lógica não correspondem exatamente aos enunciados das línguas naturais, uma vez que suas sentenças mais básicas aparecem desprovidas de força, enquanto que os enunciados possuem força assertiva (ver mais adiante nesta seção).

${ }^{10} \mathrm{O}$ uso de "expressão subsentencial" aqui é obviamente um uso estrito, a respeito de expressões que necessariamente ocorrem dentro de uma sentença, seja ela simples ou não. Em um sentido amplo, sentenças são (podem ser) também subsentenciais, uma vez que uma sentença pode ocorrer dentro de outra.
} 


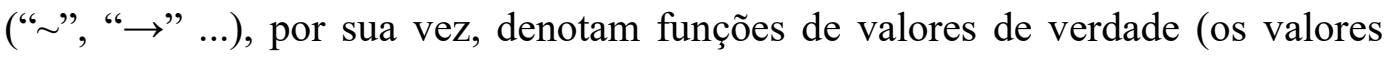
semânticos de sentenças predicativas) em valores de verdade (os valores semânticos das sentenças logicamente complexas formadas pelas sentenças predicativas e pelos operadores); e quantificadores são funções de conceitos (de predicados) a valores de verdade (cf. FREGE, 2009, cap. 5; MILLER, 2007, pp. 16-18) - ou seja, conceitos de $2^{\mathrm{a}}$ ordem, os quais mapeiam conceitos de $1^{\mathrm{a}}$ ordem em valores de verdade.

Ao caracterizar o valor semântico de predicados e termos lógicos como sendo funções, Frege nos deu uma maneira de caracterizar esses valores semânticos sem a necessidade de discutirmos sobre a sua natureza ${ }^{11}$. Ele nos permite usar uma estratégia semelhante à ascensão semântica de Quine: nominalistas e realistas dos universais podem se entender mutuamente sem cair em contradição enquanto estiverem falando de funções, ainda que cada qual tenha opiniões incompatíveis a respeito do que são funções ${ }^{12}$. Essa caracterização funcional (no sentido se ater mais ao que as coisas fazem do que ao que elas são) informal que Frege dá para a semântica da lógica clássica é bem mais "agnóstica” do que aquelas caracterizações de inspiração tarskiana - fortemente impregnadas de nominalismo - que se costuma encontrar em manuais de lógica.

Já definimos a dimensão do valor semântico como a dimensão básica da significação linguística em uma teoria clássica. Fixamos também a gramática da lógica do ponto de vista da semântica, que identificamos como sendo a gramática da lógica clássica de predicados. Agora, vamos identificar o fragmento da linguagem natural e de sua gramática que corresponde a essa gramática da lógica. A congruência entre a gramática básica da linguagem natural (a gramática do

\footnotetext{
${ }^{11}$ Há uma certa "licença poética" nessa colocação, uma vez que do ponto de vista histórico ela não é acurada. Frege interpretava os valores de verdade como sendo eles próprios objetos "lógicos" ("o verdadeiro" e "o falso"), e falava deles de um modo "ontologicamente comprometido", de modo que posteriormente ele veio a considerá-los como objetos abstratos. Estamos adotando aqui uma reconstrução deflacionada das ideias apresentadas em Função e Objeto (cf. FREGE, 2009, cap. 5) nas linhas de Miller (2007, cap. 1). Assim, os valores de verdade podem ser tomados também como propriedades ou mesmo predicados de sentenças.

12 Um realista dos universais pode interpretar uma função como sendo uma universal básico indefinível (cf. FREGE, 2009, cap. 5) ou como um tipo de relação (cf. RUSSELL, 2007, pp. 66), de modo que relações são elas próprias tidas como universais básicos (RUSSELL, 1998, cap. 9). Por outro lado, nominalistas costumam, como Russell, definir funções em termos de tipos de relações, mas ao invés de tomar relações como universais, eles as definem a partir de elementos de teoria dos conjuntos de tal modo que nessa teoria dos conjuntos só existam objetos (esse procedimento é ilustrado em MORTARI, 2001, cap 4).
} 
logiquês) e àquela da lógica é obviamente uma congruência expressiva (todo valor semântico que é expresso em um lado, é expresso no outro) e não estrutural (por exemplo, não há nada no lado da lógica que correspondam aos morfemas). E um jeito útil de procurar essa congruência expressiva é fazendo a pergunta “ $O$ quão empobrecida deve ser a linguagem natural e a sua gramática para que só se possa falar em um jargão lógico, ou seja, em um logiquês?”.

Um ponto essencial para se responder a essa questão é se atentar para o rigor e a precisão expressivas do simbolismo lógico. Quando interpretamos o vocabulário da lógica (aos moldes da lógica clássica), a cada expressão (type) é atribuído um e apenas um valor semântico dentro de um domínio de discurso. Tal rigor expressivo na semântica se manifesta na sintaxe lógica através do princípio da substituição salva veritate. Segundo tal princípio, a substituição em uma sentença (bem formada) de uma expressão por outra com o mesmo valor semântico preserva o valor semântico da sentença original. Por exemplo, no enunciado "A estrela da manhã é a estrela da manhã", se eu troco a segunda ocorrência de "estrela da manhã" por "estrela da tarde", a nova sentença gerada é também verdadeira, pois o valor semântico das expressões substituída e substituta é exatamente o mesmo, a saber, o planeta Vênus. No simbolismo lógico, o princípio da substituição deve ter, pois, aplicação absoluta.

Como consequência direta da univocidade do valor semântico, a ambiguidade, a vagueza e a polissemia - típicas da significação ordinária - teriam de ser eliminadas de modo preliminar ${ }^{13}$. Outra implicação automática da univocidade do valor semântico seria a inadmissibilidade de expressões sem nenhum valor semântico, como nomes próprios e descrições definidas que não se

\footnotetext{
${ }^{13}$ Há uma tensão entre a ideia de que não deve haver vagueza no logiquês e o compromisso com uma abordagem hermenêutica para a linguagem natural, exatamente porque a vagueza parece ser uma característica intrínseca e não analisável das linguagens naturais. Em 2.1.2 e 2.1.3 vemos alguns expedientes empregados pelos teóricos clássicos para explicar a vagueza sem abrir mão do princípio do $3^{\circ}$ excluído (i.e., sem abrir mão de ser um teórico clássico) e nem da abordagem hermenêutica. Já a remoção da polissemia e da ambiguidade é muito mais facilmente vislumbrada: elas não são propriamente problemas dos tokens, mas dos types de expressões e sentenças, dado que na maioria das vezes o contexto no qual os tokens estão inseridos é suficiente para desambiguizar o significado dos types aos quais eles pertencem. Desse modo, a polissemia é eliminada automaticamente sem prejuízo expressivo pela própria precisão semântica que estamos estipulando (algum aspecto da significação é necessariamente invariável para cada expressão no simbolismo e no logiquês que é a sua contraparte). Por outro lado, se há tokens que permanecem ambíguos mesmo sendo contexutalizados, então o proferimento no qual esse token consiste não pode ser considerado como comunicando propriamente algo.
} 
refiram a nada. Nesses casos, essas expressões receberiam um tratamento de acordo com a teoria das descrições de Russell (cf. RUSSEL, 2007, cap. 16) ${ }^{14}$; tais expressões se dissolveriam, por assim dizer, quando o enunciado no qual elas ocorrem fosse parafraseado no jargão lógico: “O atual rei da França é calvo" tem que ser parafraseado no logiquês em algo como "Há pelo menos um rei da França, e não há mais de um rei da França, e ele é calvo". ${ }^{15}$

Um ponto mais delicado para a definição de uma gramática natural básica expressivamente congruente com a gramática lógica envolve a aplicação do princípio da substituição à linguagem comum. Consideremos agora, juntamente com o enunciado do exemplo anterior ("Estrela da manhã é a estrela da manhã"), o enunciado "Hamurabi sabia que a estrela da manhã é a estrela da manhã". Se substituirmos a expressão "estrela da manhã" por "estrela da tarde" nesse último enunciado, o valor de verdade da sentença resultante não é o mesmo que o valor da sentença original. "Hamurabi sabia que a estrela da manhã é a estrela da manhã" é trivialmente verdadeiro (se consideramos que Hamurabi conhecia a estrela da manhã e era minimamente racional a ponto de aceitar o princípio da identidade). Mas o enunciado resultante da substituição é falso, pois o fato de que as expressões "estrela da manhã" e "estrela da tarde" se referem ao mesmo objeto só foi conhecido muito depois da morte do líder babilônio. Disso tudo resulta que o valor semântico

\footnotetext{
${ }^{14}$ Frege sugere que se fôssemos desenvolver uma semântica para a linguagem natural, adotando uma abordagem hermenêutica para sua característica universal, então pelo menos alguns nomes careceriam de denotação (nomes ficcionais, por exemplo). Mas, uma vez que a abordagem fregeana não é exatamente hermenêutica, mas de desenvolver uma característica universal para propósitos científicos (cf. FREGE, 2009, pp. 136-138), ele está na verdade de acordo com Russell quando este insiste que termos singulares devem sempre denotar um objeto.

15 Notemos que mesmo nessa paráfrase ainda ocorrem expressões como "algo", "esse" e "que". Elas cumprem função indexical e anafórica: algum aspecto da significação dessas expressões é constante em todos os contextos de uso, mas esse aspecto certamente não é o valor semântico. O que "esse" ou "que" denotam varia de acordo com as circunstâncias em que o enunciado onde eles ocorre é proferido. E o pior é que eles parecem ser indispensáveis mesmo dentro dessa gramática natural básica: parece que nós não podemos falar em "logiquês" dispensando os recursos da anáfora e da indexicalidade. De repente parece que não podemos mais traduzir nada para o simbolismo lógico preservando inteiramente seu poder expressivo original! A solução creio eu, consiste justamente em rejeitar a ideia de que algum poder expressivo é perdido na paráfrase: congruência expressiva entre linguagem comum e lógica não é a mesma coisa que congruência estrutural. Os fenômenos da indexicalidade e da anáfora não são representados simbolicamente na lógica, mas isso não significa que termos indexicais e anafóricos não sejam "absorvidos" na análise lógica. Eles são tão absorvidos quanto os morfemas e as preposições, que também não tem correspondente estrutural na lógica. Termos indexicais e anafóricos "desaparecem" na análise lógica da mesma forma que "desaparecem" os nomes vazios.
} 
de "estrela da manhã" no primeiro exemplo não pode ser idêntico ao valor semântico de "estrela da manhã" no segundo exemplo. O tokens de um mesmo type aparecem com valores semânticos diferentes enunciados diferentes. Assim, parece que no caso da linguagem comum, o princípio da substituição não tem, como no simbolismo lógico, uma abrangência absoluta.

$\mathrm{Na}$ linguagem comum, o valor semântico costumeiro de uma expressão é dado, paradigmaticamente, quando elas ocorrem em períodos simples (como em "A estrela da manhã é a estrela da tarde"). ${ }^{16}$ Esses contextos discursivos da linguagem comum, para os quais sempre vale o princípio da substituição, são chamados de contextos extensionais ou transparentes. A esses últimos se contrapõem os contextos intensionais ou opacos (como em "Hamurabi sabia que a estrela da manhã é a estrela da tarde"), onde o valor semântico das expressões que ocorrem na oração subordinada não é aquele costumeiro; ele é, contudo, um valor "secundário", "indireto", de algum modo parasitário ao valor semântico costumeiro. Os contextos intensionais são, em geral, marcados do ponto de vista sintático pela ocorrência de subordinação ${ }^{17}$; do ponto de vista semântico, a intensionalidade se manifesta pela ocorrência, na oração principal, de expressões indicando atos e estados mentais e cognitivos de um sujeito (crença, desejo, dúvida, certeza, compreensão, entendimento etc.) e modalidades (necessidade, possibilidade, obrigatoriedade, proibição etc.).

Um teórico clássico do significado pode tanto admitir quanto rejeitar a ocorrência de contextos intensionais em sua gramática do logiquês. Se ele admitir o vocabulário intensional, ele terá de interpretá-lo de alguma maneira capaz de assegurar a prevalência do princípio da substituição do lado da lógica: as expressões

\footnotetext{
${ }^{16}$ Em períodos compostos por coordenação, nos quais as conjunções coordenativas fazem o papel de conectivos lógicos "e" e "ou", as orações e seus termos também aparecem com seu valor semântico costumeiro. Há, contudo, exceções; o condicional e o bicondicional da lógica se manifestam na linguagem comum através de períodos compostos por subordinação ("Se o sol nasce, o galo canta") onde todas as expressões ocorrem com seu valor semântico costumeiro. Outro caso de destaque em que o valor semântico costumeiro ocorre juntamente com a subordinação envolvem as construções "veritativas", como "É o caso que...", "Acontece que". Tomo tais construções veritativas como supérfluas tendo em vista a gramática básica para a linguagem comum.

${ }^{17}$ A ocorrência mencionada - e não usada, de uma expressão - parece constituir uma exceção a essa regra. Tanto (i) “Cícero é Túlio" quanto (ii) " “Cícero' tem seis letras” constituem orações simples, mas nem por isso podemos trocar "Cícero" por "Túlio" em (ii). Um modo fácil de evitar essa exceção é considerar as aspas que indicam a menção como parte da expressão subsentencial, e não da própria sentença. Assim, a estrutura da sentença (ii) é interpretada como “ ، ' tem 6 letras, de forma que fique claro que a função toma como argumento types de expressões linguísitcas e não o valor semântico delas.
} 
intensionais devem ser interpretadas como funções (e, uma vez que a interpretação delas não varia de acordo com domínio do discurso, elas poderiam aparecer na notação simbólica como operadores); e as orações subordinadas, onde as expressões ocorrem sem o seu valor semântico usual, poderiam ser interpretadas como conteúdos proposicionais. Esta é a estratégia geral empregada, por exemplo, por D. Lewis e Frege - embora cada um à sua maneira (cf. 2.1.3 e 2.1.4). ${ }^{18}$ Agora, se o teórico clássico quiser rejeitar a intensionalidade, então ele deverá fazê-la desaparecer inteiramente através da análise lógica, ou seja, não deve haver na notação lógica nenhuma expressão correspondente a expressões intensionais. Vocabulários sobre atos e estados mentais e modalidades não são considerados espúrios, mas são considerados apenas como "abreviações notacionais" de construções envolvendo vocabulário extensional. Esse foi o caminho tomado pelos behavioristas lógicos e, até certa fase, por Wittgenstein (cf. TLP 5.54-5.5423; cf. Observações Filosóficas, parte VI). O extensionalismo é, com efeito, a ideia de que o poder expressivo de toda e qualquer linguagem é se esgota no poder expressivo da lógica clássica de primeira ordem. Retomamos esse ponto em mais detalhes em 2.1.2. A indexicalidade e a anáfora são outros dois fenômenos que merecem atenção ao buscarmos dar às linguagens naturais uma análise que satisfaça a univocidade do valor semântico próprio do simbolismo lógico.

Os indexicais são expressões da linguagem comum cujo valor semântico varia em função das circunstâncias do contexto de uso. Elas possuem a forma gramatical especialmente de pronomes e de advérbios de tempo e lugar ("isto", “aquilo", "aqui", “eu”, “agora" etc). Por exemplo, se eu falo "Está chovendo onde eu estou agora", o valor semântico desse enunciado vai depender de vários elementos circunstanciais: da pessoa que fala, do lugar de onde essa pessoa fala e do tempo do proferimento. ${ }^{19}$ Os indexicais, entretanto, também possuem uma

\footnotetext{
${ }^{18}$ Intensionalistas dos mundos possíveis como Lewis, embora não adotem uma lógica extensional como característica universal, costumam usar os modelos semânticos de mundos possíveis de Kripke, que são ampliações conservadores das lógicas extensionais clássicas. Seus "apêndices" intensionais são em última análise definidos em termos puramente extensionais, o que faz com que todo o vocabulário modal ainda possa ser definido em um vocabulário extensional básico (cf. seção 2.1.3).

${ }^{19}$ Nesse exemplo, a circunstância do proferimento do enunciado e a circunstância de avaliação do valor de verdade do enunciado coincidem. Mas essa coincidência não é algo necessário, e um enunciado pode ser duplamente indexado. Por exemplo, em "Há cem anos o Rio de Janeiro era a
} 
dimensão da significação que permanece constante qualquer que seja o contexto de uso.

Considerando os indexicais que na linguística costuma se chamar de "pessoa do discurso", creio que elas sejam totalmente analisáveis em termos da terceira pessoa, que contém uma "perspectiva" objetiva. O enunciado "Eu sou carioca", dito por mim, pode ser parafraseado como "TMG é carioca", sem perda expressiva ao nível do valor semântico

Os indexicais de tempo e lugar trazem à baila a discussão sobre tempo e espaço. Enunciados contendo indexicais como "aqui" e "agora" devem igualmente ser parafraseados de modo que adquiram uma perspectiva objetiva, na paráfrase em logiquês, os advérbios indexicais devem ser substituídos por advérbios (e locuções adverbiais) não indexicais. Por exemplo, o enunciado "Pedro janta aqui e agora" poderia ser analisado como "Pedro janta na casa de TMG na noite do dia....". O ponto de discussão torna-se então como tratar, do ponto de vista lógico, esses advérbios não indexicais de tempo e lugar. No caso da temporalidade então, há ainda um complicador adicional: circunstâncias temporais de um enunciado são expressas também por meio de tempos verbais.

Em relação à questão do espaço, o teórico clássico pode interpretar regiões do espaço como objetos do ponto de vista lógico, tomados como argumentos de funções com dimensão espacial. Assim, o enunciado em logiquês "Pedro janta na casa de TMG" aparecia na notação lógica com a forma "Rab", onde um dos nomes tem como valor semântico a região do espaço que corresponde à casa de TMG.

A questão da temporalidade foi mais abordada na literatura filosófica e para ela não há uma resposta mais óbvia ou simples a ser dada. Uma opção é fazer o tempo aparecer na notação lógica através de operadores lógicos temporais, e "cortar a realidade em fatias", de modo que a cada fatia corresponda um intervalo temporal, e cada fatia seja ela própria um universo de discurso, com objetos e funções. Nessa toada, teríamos uma lógica modal temporal em que os enunciados da linguagem comum apareceriam no logiquês no presente do indicativo mais alguma expressão correspondente ao operador. Por exemplo, o enunciado "Pedro jantou" seria parafraseado como "Em algum momento do passado, Pedro janta" (o operador "em algum momento do passado" funciona como um quantificador que varre as várias de 2020, mas a circunstância temporal de avaliação é o ano de 1920. 
fatias temporais anteriores ao momento do proferimento, conduzindo ao valor de verdade verdadeiro se em alguma dessas fatias o enunciado "Pedro janta" é verdadeiro).

Alternativamente, o fenômeno da temporalidade poderia ser interpretado do mesmo modo que o da espacialidade. Poderíamos representar instantes temporais como objetos dentro de um único domínio de discurso. Nessa interpretação, não há passado, presente ou futuro, mas apenas instantes temporais caracterizados objetivamente (as frases do logiquês tem como tempo verbal o presente do indicativo, mas aqui se trata de um presente "atemporal"). Uma frase no momento presente, nessa interpretação, não é analisada como uma frase sem operador temporal, mas uma frase que dá como objeto temporal o intervalo de tempo no qual o sujeito a profere. Por exemplo, "Chove agora na cidade do Rio" seria parafraseada em logiquês como "Chove na cidade do Rio às ... do dia ...". Essa análise tem a vantagem óbvia da simplicidade explicativa, ou seja, de unificar as explicações para o tempo e o espaço. ${ }^{21}$

O fenômeno da anáfora, por sua vez, ocorre quando uma expressão linguística obtém o seu valor semântico de outra expressão linguística dentro de um determinado contexto discursivo. Por exemplo, em "Maria se veste", o pronome "se" recupera o valor semântico do nome que imediatamente o antecede. Termos anafóricos são como mandatários ou procuradores, atuando em um dado contexto discursivo em nome de outrem. Quando a expressão anafórica paradigmaticamente um pronome $\mathrm{p}^{22}$ - faz referência a um termo singular especificado, ela obviamente pode ser substituída, no lado da sintaxe lógica (e do

\footnotetext{
${ }^{20}$ Esse é um modo de interpretar o discurso temporal como sendo um discurso logicamente intensional, a ser acomodado por uma lógica modal temporal (cf. GIRLE, 2009, cap. 10).

${ }^{21}$ A análise do tempo e do espaço como objetos foi sustentada por Frege (2009, p. 148): "Lugares, instantes intervalos de tempo são, sob o ponto de vista lógico, considerados objetos; e portanto a designação linguística de um lugar determinado ou de um intervalo de tempo determinado deve ser considerada um nome próprio (termo singular)". Nessa interpretação em que espaço e tempo são objetos, a maioria dos predicados seriam pelo menos triádicos. Por exemplo, "Ana dorme" não teria como forma lógica a forma predicativa singular "Fa", mas "Fabc", onde "b" e "c" estão por instantes temporais e regiões espaciais.
}

${ }^{22}$ Notemos que a maioria dos pronomes das linguagens naturais podem funcionar tanto como indexicais como anáforas. Se eu falo "Aquele carro é verde", apontando para o carro, o pronome é um indexical; a identificação valor semântico depende do meu gesto dêitico, o que é, strictu sensu, um elemento extralinguístico. Por outro lado, se eu falo com um amigo "Aquele carro que você acabou de mencionar", então meu token de "aquele" é anafórico, deferindo o seu valor semântico ao valor semântico de uma expressão que meu amigo havia usado. 
logiquês) pelo próprio termo singular (no exemplo em questão, a análise óbvia é "Maria veste Maria"). Nos casos em que a expressão anafórica tem um valor semântico indefinido, ela aparece no lado da sintaxe lógica como uma variável no escopo de um quantificador, como no célebre exemplo de Russell (“Existe um x tal que x é o rei da França...).

Uma questão transversal que se coloca para qualquer teórico do significado diz respeito a que (tipos de) objetos devem ser considerados fundamentais no domínio de discurso. O simbolismo lógico é liberal o suficiente para tomar qualquer tipo de coisa como objeto: partículas fundamentais da física, objetos cotidianos, dados sensoriais etc. A escolha de quais objetos (e suas respectivas características) serão tomados como mais básicos envolve posições substantivas em epistemologia e metafísica. O teórico pode optar por uma posição fisicalista e tomar objetos do mundo natural como sendo a base de seu domínio de discurso, e pensar objetos de outra natureza (por exemplo, objetos matemáticos) como sendo de algum modo derivados daqueles. Mesmo dentro do fisicalismo, deve-se escolher entre os objetos ontologicamente mais fundamentais (que seriam partículas da melhor teoria física) ou os epistemicamente mais fundamentais (objetos concretos cotidianos, apreensíveis pela percepção). Mas o teórico do significado pode tomar também um caminho fenomenológico, considerando mais básicos os dados sensoriais e os seus atributos, e aqui ele deve novamente optar por "ontologicamente" ou "epistemicamente" fundamental. Se se pensa em dados sensoriais como ontologicamente fundamentais, assume-se uma posição fenomenalista em metafísica, de modo que os objetos cotidianos seriam tomados como construtos lógicos feitos a partir desses dados. Agora, se esses dados sensoriais são tomados como epistemicamente, mas não ontologicamente fundamentais, deve ser assumida alguma forma de realismo indireto (i. e., o conhecimento de objetos físicos do mundo exterior deve ser de algum modo derivado partir dos objetos sensoriais do mundo interior).

Há ainda muitos vocabulários filosoficamente interessantes (e problemáticos) dos quais não falamos que costumam ser tratados como não básicos e que, de algum modo, tem de ser acomodados em uma teoria semântica: vocabulário moral e estético, vocabulário matemático, vocabulário semântico (em especial expressões veritativas como "é verdadeiro", "verdade" ...), vocabulário causal, e o extremamente intrigante e cientificamente destacável condicional 
subjuntivo ("se fosse o caso que ... então....").

Toda essa discussão precedente envolveria diretamente apenas o nível do valor semântico, que é tomado em uma teoria clássica como sendo o nível explicativamente mais básico da significação linguística. Este nível é chamado de teoria da referência. Há, entretanto, outros aspectos da significação filosoficamente relevantes a serem explicados por outras "camadas" de uma teoria semântica. A camada que via de regra vem "acima" de uma teoria semântica (em uma teoria semântica clássica) é o que costuma ser chamado de teoria do conteúdo (SPEAKS, 2020) ou teoria do sentido (MILLER, 2007, p. 59).

Uma teoria do sentido busca explicar o conhecimento que, dada uma linguagem natural qualquer, os sujeitos tem da teoria da referência para essa linguagem (DUMMETT in EVANS \& MCDOWELL, 2005, p. 74). Em outras palavras, uma teoria do sentido toma a tarefa de explicar o fenômeno da compreensão ou do entendimento de expressões dos sujeitos usuários da linguagem. E ela faz isso estabelecendo as condições necessárias e suficientes para que um sujeito seja considerado como tendo a habilidade de representar o mundo e interagir com ele - incluindo os outros sujeitos - através da linguagem. ${ }^{24}$ Além disso, uma vez que a linguagem e o pensamento possuem uma estrutura em comum, uma teoria do sentido deve por consequência explicar a capacidade dos sujeitos de pensar sobre o mundo - pensar sobre as coisas e fatos no mundo e articular inferencialmente esses pensamentos do modo correto.

\footnotetext{
${ }^{23}$ Condicionais subjuntivos ou contrafactuais parecem ser verdadeiros em função de fatos que simplesmente não aconteceram, não estão acontecendo e talvez nunca venham a ocorrer. Por exemplo, "Se eu morasse na China, falaria mandarim." Eles são especialmente problemáticos para os teóricos extensionalistas, porque o condicional material da lógica clássica não traduz exatamente aquilo que eles comunicam. Qualquer sentença condicional cuja sentença antecedente é trivialmente verdadeira, mas condicionais subjuntivos certamente não o são. "Se eu morasse na China, teria escamas" é obviamente falso. Ainda, condicionais subjuntivos são fundamentais para o discurso científico, uma vez que muitas propriedades físicas são analisadas como sendo disposicionais. Uma complicação extra é que, quando eles são verdadeiros, normalmente o são ceteris paribus: se eu morasse na China, mas sofresse uma lobotomia que me retirasse a área do cérebro responsável pela linguagem, eu não falaria mandarim.
}

${ }^{24}$ Uma teoria do sentido aqui não deve ser entendida (pelo menos não necessariamente) como uma teoria que vá se ocupar dos mecanismos psicológicos envolvidos no compreensão linguística e na comunicação. Segundo Dummett (EVANS \& MCDOWELL, 2005, p. 70): "Se um marciano pudesse aprender uma linguagem humana, ou um robô fosse projetado para se comportar exatamente nos modos que são essenciais a um falante da linguagem, um conhecimento implícito da correta teoria do significado para aquela linguagem poderia ser atribuído ao marciano ou ao robô com o mesmo direito que a um falante humano, ainda que os mecanismos internos fossem inteiramente diferentes". 
A pedra fundamental de uma teoria clássica do sentido é a ideia de que compreender um enunciado é saber o que deve ser o caso se ele for verdadeiro, e, por conseguinte, que compreender o significado de uma expressão subsentencial é saber a contribuição que ela dá para as condições de verdade do enunciado. (TLP 4.024). O aspecto do significado que é apreendido pelo sujeito quando ele compreende uma expressão é o sentido (sense) dessa expressão (MILLER, 2007, p. 29). O sentido vem a cumprir uma série de lacunas explicativas que são deixadas em aberto pela teoria da referência: ele pode ser identificado como o valor semântico secundário de uma expressão - que ocorre em contextos intensionais; como o objeto de atos e estados mentais intencionais (crença, desejo, dúvida etc), como aquele aspecto de um indexical que é invariável; como o "conteúdo" de um token de enunciado, tradicionalmente chamado de proposição; e como aquilo que duas expressões sinônimas têm em comum.

A divisão entre teóricos clássicos extensionalistas e intensionalistas, mencionada anteriormente, se expressa na teoria do sentido através da posição que eles assumem a respeito da natureza dos sentidos. Teóricos intensionalistas tomam sentidos como sendo algum tipo de coisa que pode figurar como valor semântico de uma expressão: sentidos podem ser entidades teóricas abstratas (cf. 2.1.4 ), conjuntos de (e funções de conjuntos em) mundos possíveis (cf. 2.1.3 ) ou tipos de objetos e processos psicológicos interiores (procurar um exemplo, se houver). Por outro lado, teóricos extensionalistas rejeitam inteiramente qualquer tipo de postura hipostática sobre o sentido, negando que haja "sentidos" (cf. 2.1.2): todo o discurso sobre sentidos, na medida em que é um tipo de discurso intensional, deve desaparecer em uma análise lógica em termos da lógica clássica de $1^{\mathrm{a}}$ ordem.

Por fim, resta um aspecto essencial da significação linguística particularmente um aspecto de sentenças - que uma teoria semântica tem a obrigação de explicar. Salientamos anteriormente que no simbolismo lógico todas as sentenças são expressivamente equivalentes a sentenças declarativas na linguagem natural, haja vista que toda sentença no simbolismo deve possuir um valor de verdade. Entretanto, a linguagem tem muitas outras funções além da função representacional. Sujeitos usuários de linguagem fazem questões, definições, promessas, pedidos, emitem ordens, expressam desejos e emoções, entre muitas outras coisas. E eles fazem isso por meio de sentenças em relação às quais não faz sentido perguntar se são verdadeiras ou falsas. Tomando emprestada a metáfora do 
$2^{\circ}$ Wittgenstein, cada proferimento feito por um sujeito dentro de um contexto cada ato de fala - é como um lance feito dentro de um jogo. Pelo menos algumas dessas diferenças de tipo de lance são capturadas pelas gramáticas das línguas indoeuropeias através dos modos verbais, indicados por meio de sinais e desinências verbais (por exemplo, sentenças declarativas e interrogativas são pontuadas diferentemente quando escritas, e são entoadas diferentemente quando faladas). O aspecto do significado que é responsável por uma sentença ser do tipo que ela é (o que é expresso em parte pela sua forma gramatical em função do modo verbal, em parte pelo contexto) é chamado, também tributariamente à obra de Frege, de força. A força de uma sentença indica o ato de fala que é realizado quando se usa essa sentença. Por exemplo, as sentenças "Abra a porta”, “A porta está aberta" e "A porta está aberta?" tem significações diferentes apenas em função de terem diferentes forças, e constituírem diferentes atos de fala. Frege se atentou para esse ponto e introduziu em seu simbolismo lógico recursos expressivos para separar o conteúdo proposicional de uma sentença da força com a qual esse conteúdo é utilizado. O conteúdo conceitual (ou proposicional) de uma sentença seria simbolizado pela variável proposicional prefixada por uma barra horizontal (“- $p$ “), representando o sentido da sentença enquanto um "conteúdo não julgado”, ou seja, um conteúdo em relação ao qual o sujeito que o apreende ainda não realizou nenhum ato específico. ${ }^{25} \mathrm{~A}$ força, por sua vez, seria simbolizada por algum traço associado ao prefixo (Frege criou uma notação apenas para a força assertiva, que ele simbolizou pela aposição de uma barra vertical ao traço prefixo: “F p") Posteriormente, Austin e, principalmente, Searle, desenvolveram uma sofisticada teoria dos atos de fala.

A primazia da força assercional sobre as demais se revela exatamente na

\footnotetext{
${ }^{25}$ Um conteúdo proposicional compartilhado por sentenças com diferentes forças seria expresso na linguagem natural na forma de uma oração subordinada, no modo subjuntivo: "que $p$ ". Poderíamos interpretar as sentenças de qualquer formalismo lógico dessa forma ao invés de interpretarmos, como usualmente fazemos, como já pressupondo uma força assercional? Creio que não. Esse conteúdo, considerado abstratamente e que pode igualmente estar presente em uma afirmação, uma pergunta, um pedido, um comando etc não é ele próprio ainda passível de ser verdadeiro ou falso (cf FREGE, p 329). Um conteúdo proposicional só é uma proposição (que Frege chama de Gedanke e que nós traduzimos como pensamento), ou seja, só é um conteúdo que é verdadeiro ou falso se ele é considerado dentro de um contexto específico com tempo e lugar. A sentença "Eu estou como fome" dita por mim enquanto escrevo e dita pela minha irmã cinco minutos antes compartilham um mesmo conteúdo proposicional, mas não são expressam de modo algum a mesma proposição. Poderíamos dizer que conteúdos proposicionais são funções que tomam contextos (espaço, tempo, sujeito) como argumentos e produzem proposições como valores.
} 
escolha do modo indicativo como sendo o único modo do logiquês. Sentenças não declarativas podem ser parafraseadas em enunciados sem perda expressiva ao nível do valor cognitivo, mas não o contrário. Por exemplo, um token de "Abra a porta", proferido por um sujeito dentro de um determinado contexto, poderia ser parafraseado como "Sujeito s deseja/pede/ordena que s' torne o caso que a porta está aberta" ou algo do gênero. O contrário, entretanto, não é possível; haveria assim uma dependência assimétrica entre o ato assercional e os demais atos de fala, de modo que é possível entender o que é uma asserção sem precisar entender qualquer outro ato de fala, mas só é possível entender um comando, um pedido ou pergunta se já se tem o entendimento (ainda que tácito) prévio do que é asserir. ${ }^{26}$

Não estou certo de que outros aspectos da significação de natureza pragmática deveriam ser abordados. Tais aspectos são, sobretudo, abordados pela teoria das implicaturas (tanto conversacional como convencional) e pelas teorias que se ocupam da linguagem figurada. ${ }^{27}$ São aspectos da significação que envolvem questões que não são apenas conceituais, mas também empíricas - a respeito dos processos psicológicos dos sujeitos envolvidos na comunicação: por exemplo, como um sujeito consegue dar algo a entender além do significado literal de um proferimento, ou para que servem as metáforas. O que estamos chamando de teoria semântica aqui, entretanto, realiza plenamente a sua tarefa ao explicitar a forma lógica de cada proferimento contextualmente situado (o que seria equivalente a perguntar: "Que pensamento(s), exprimível no logiquês, este proferimento está comunicando?"), sem se preocupar com os processos heurísticos inconscientes que permitem aos sujeitos apreender aquilo que um proferimento está dando a entender. $^{28}$

\footnotetext{
${ }^{26}$ Obviamente uma asserção pode ser feita por meio de sentenças não declarativas - como uma pergunta retórica, por exemplo. Mas esse seria um típico caso de força indireta, onde há uma assimetria entre a forma gramatical e a forma lógica da sentença no que tange à força - isto é, o modo verbal da sentença não está sendo utilizado com o seu sentido canônico, literal.

${ }^{27}$ No presente trabalho estou presumindo a prioridade conceitual do sentido literal sobre o sentido figurado, ou seja, o significado de um enunciado metafórico pode ser plenamente analisado em termos de enunciados literais, mas não o contrário. Isso não quer dizer que, do ponto de vista dos processos psicológicos, o entendimento da linguagem figurada seja mais "custoso" do que o da linguagem literal. Pesquisas empíricas podem muito bem concluir que o uso da linguagem figurada em quase todos os contextos agiliza e facilita a comunicação, sem que isso afete a prioridade conceitual do literal sobre o metafórico.

${ }^{28}$ É também de Frege que recebemos as sugestões de como "acomodar" o que hoje chamamos de implicaturas em uma teoria do significado: “(...) Quase sempre, ao que parece, aos pensamentos
} 
Ao término desta longa subseção, vamos recapitular agora os principais traços característicos do que nos permitiria enquadrar uma dada teoria semântica como sendo uma teoria clássica:

(1) prioridade explicativa do aspecto representacional da significação linguística sobre os demais, traduzida na prioridade explicativa da teoria da referência (especialmente para sentenças simples e suas partes componentes) a teoria do sentido e a teoria da força - representacionismo;

(2) prioridade explicativa da força assercional sobre as demais forças sentenciais (expresso pela redução de todos os modos verbais ao modo indicativo);

(3) prioridade da dimensão contextualmente invariável da significação sobre quaisquer outras dimensões contextualmente variáveis (o que é expresso pela redução de todos os indexicais a pronomes indefinidos usados para quantificação e anáfora, e da redução de todos os tempos verbais ao tempo presente);

(4) lógica clássica de $1^{\mathrm{a}}$ ordem como núcleo da lógica alçada ao status de característica universal (princípio da identidade, princípio da não contradição, princípio do terceiro excluído e infalibilidade denotacional dos termos singulares em toda interpretação sobre um domínio de discurso).

O esboço de inferencialismo que pretendo defender neste trabalho rejeita categoricamente (1), endossa (2) e (3) e assume uma postura agnóstica em relação a (4). ${ }^{29}$

\subsubsection{Extensionalismo clássico}

principais (Hauptgedanken) que expressamos associamos pensamentos secundários (Nebengedanken) que, embora não expressos, são vinculados às nossas palavras, inclusive pelo ouvinte, consoante leis psicológicas. E dado que esses pensamentos secundários parecem espontaneamente associados às nossas palavras, quase tão espontaneamente quanto o próprio pensamento principal, parece então que queremos expressar esses pensamentos secundários tanto quanto queremos expressar o pensamento principal.” (FREGE, 2009, pp. 71-72).

\footnotetext{
${ }^{29}$ Uma vez que estamos assumindo uma atitude hermenêutica em relação à linguagem ordinária, é provável que ao menos alguns dos seus fragmentos não sejam interpretados classicamente do ponto de vista lógico. A maior parte do discurso de senso comum de $1^{\mathrm{a}}$ ordem envolve uma vagueza não eliminável. Em termos lógicos, isso quer dizer que muitos predicados possuem um comportamento lógico difuso: há contextos discursivos nos quais sentenças envolvendo um predicado $\mathrm{F}$ não são nem determinamente verdadeiras nem determinantemente falsas, sem que isso implique em F ser sentido, nem mesmo em um tal contexto. Por exemplo, quantos fios de cabelo alguém deve ter para ser considerado calvo? Como deve ser a distribuição capilar? É uma tese em princípio plausível que a correção ou não da atribuição do predicado "calvo" a algumas pessoas seja categoricamente indeterminada.
} 
Definimos como extensionalismo clássico qualquer teoria semântica que tome a lógica clássica como sendo a característica universal. Teorias extensionais experimentaram seu período áureo nos anos 1920 e 1930, especialmente por influência do Tractatus de Wittgenstein, entrando em decadência na década seguinte tanto por razões filosóficas (a versão atomista de extensionalismo clássico proposta pelo Tractatus foi logo considerada pelo próprio Wittgenstein como irremediavelmente errada) quanto por razões históricas (a ascensão do nazismo pôs fim ao Círculo de Viena - e os seus membros eram grandes entusiastas do projeto na época). Entretanto, a ideia tractariana de que a lógica clássica (especificamente a lógica clássica de $1^{\mathrm{a}}$ ordem) é $a$ lógica começou a ser resgatada ainda no final dos anos 1960 por Donald Davidson, com sua proposta de aplicar a semântica formal de Tarski para as linguagens naturais. ${ }^{30}$ Tomamos aqui o projeto de Davidson como o paradigma de teoria clássica extensional pela sua enorme influência e prestígio, de modo que concebemos algum desenvolvimento desse projeto como sendo a melhor versão possível de uma teoria clássica extensional.

Também definimos acima que uma postura representacionista - de tomar o valor semântico das expressões como o nível fundamental da significação - é um traço essencial de uma teoria clássica, sem, contudo, dizer se há ou não uma categoria sintática a ser privilegiada. Em outras palavras, não respondemos à questão "Qual o valor semântico explicativamente mais básico, se houver? O de termos singulares, predicados ou sentenças?". O ponto de partida de Davidson é justamente responder essa questão estabelecendo o valor de verdade "verdadeiro" das sentenças como sendo $o$ atributo básico da significação, em função do qual todos os outros - incluindo o valor semântico dos termos subsentenciais - devem ser definidos. A partir daí, Davidson busca então uma definição extensional do valor de verdade verdadeiro: o conjunto de coisas às quais o predicado "é verdadeiro" se aplica. E ele encontra isso exatamente nos moldes das semânticas formalizadas desenvolvidas por Tarski.

As semânticas tarskianas permitem definir verdade para uma estrutura (no

\footnotetext{
${ }^{30}$ A ideia de que a lógica clássica de $1^{\mathrm{a}}$ ordem é $a$ lógica encontrou em Quine seu principal advogado entre os anos 1940 e 1970. Entretanto, como já apontamos anteriormente, Quine tinha uma postura revisionista e não hermenêutica, em relação à linguagem natural. Quine rejeitava a ideia de que sua filosofia deveria acomodar qualquer discurso intensional. Assim, não consideramos que a filosofia da linguagem de Quine oferecesse uma teoria do significado. Coube exatamente a Davidson, aluno de Quine, transpor muitas de suas ideias para o seu programa .
} 
caso, para uma linguagem formal e uma interpretação dessa linguagem em um domínio de objetos) oferecendo uma maneira de gerar um conjunto de sentenças que na metalinguagem (no caso, uma linguagem natural acrescida da teoria dos conjuntos) envolvam o predicado "é verdadeiro" sendo aplicado a uma sentença da linguagem formal. A "lista” com todas as sentenças geradas desse modo constituem o que Tarski chamou de teoria da verdade, e as sentenças que compõem essa lista são chamadas de sentenças-T. Podemos ver como isso funciona seguindo a sugestão de Lycan (2000, pp. 134-136) tomando uma estrutura extremamente simples como ilustração.

Seja L um subconjunto da linguagem da lógica de predicados de $1^{\mathrm{a}}$ ordem, de modo que $L$ possui como vocabulário ' $F$ ' e ' $G$ ' como predicados, ' $a$ ' e 'b' como nomes e ' $\sim$ ' como o único conectivo lógico, e seja o nosso universo um conjunto formado por apenas duas pessoas, Alice e Beatriz. Suponhamos que 'a' se refira a Alice, 'b' se refira a Beatriz, que os predicados ' $F$ ' e ' $G$ ' se apliquem a coisas que são filósofos e geógrafos, respectivamente, e ainda que ' ’ funcione normalmente aqui, como uma negação. Uma teoria da verdade para L nessa estrutura precisaria apenas de duas cláusulas para ser gerada:

(i) Se $P$ é um predicado e n é um nome, então a sentença ' $P$ n' é verdadeira se e somente se $\mathrm{n}$ se refere a um membro do conjunto das coisas que satisfazem $P$;

(ii) Se $s$ é uma sentença (bem formada), então $\sim s$ é verdadeira se e somente se $s$ não é verdadeira;

As sentenças-T de L para essa estrutura seriam as seguintes:

(1) 'Fa' é verdadeira se e somente se Alice é filósofa;

(2) ' $F b$ ' é verdadeira se e somente se Beatriz é filósofa;

(3) 'Ga' é verdadeira se e somente se Alice é geógrafa;

(4) 'Gb' é verdadeira se e somente se Beatriz é geógrafa;

e ainda todas as demais sentenças geradas a partir da aplicação da cláusula (ii) a essas quatro sentenças (que pode ser uma aplicação reiterada, ou seja, teríamos 
também sentenças como ““ Gb' é verdadeira se e somente se Beatriz é geógrafa" ${ }^{31}$ Chegamos então à forma geral de uma sentença-T, que é:

\section{$s$ é verdadeira se e somente se p,}

onde 's' é uma sentença da linguagem objeto e 'p' é uma paráfrase ou tradução de 's' na metalinguagem.O insight de Davidson consiste basicamente em aplicar esse mesmo maquinário para gerar lista de sentenças-T para uma linguagem natural qualquer. No lado esquerdo do bicondicional seria mencionada uma sentença da linguagem natural, e do lado direito do bicondicional seria usada uma paráfrase ou tradução em logiquês (de uma linguagem natural) da sentença mencionada (cf. Davidson, 1991, Ensaios 2 e 4) Exemplos com os quais Davidson trabalha em seus textos são normalmente banais porque ele escolhe sentenças onde a forma gramatical e a forma lógica coincidem (por exemplo, "A neve é branca' se e somente se a neve a branca), o que acaba ocultando um pouco o valor filosófico de sua proposta. Mas a construção de teorias tarskianas da verdade para linguagens naturais é no final das contas um expediente, colocado a serviço da boa e velha análise lógica da linguagem comum exaltada no Tractatus. ${ }^{32}$

Agora, Miller (2007, pp. 288-289) chama atenção para um ponto crucial. A definição do que é uma sentença-T pressupõe o que é uma tradução ou paráfrase corretas, isto é, toma por garantida a ideia de que a sentença mencionada na linguagem-objeto e sentença usada da metalinguagem são sinônimas, possuem o mesmo sentido. Isso não é problemático quando o uso de uma teoria tarskiana da

\footnotetext{
${ }^{31}$ Mesmo do ponto de vista estrutural essa apresentação de uma teoria tarskiana da verdade é adptada. Para uma apresentação historicamente mais fiel à proposta de Tarski, cf. KIRKHAM, 2003, cap. 5.
}

\footnotetext{
${ }^{32}$ A proposta de construção de uma teoria semântica de Davidson é tecnicamente mais ambiciosa que a maioria das demais. Davidson pretendia que as sentenças-T de uma linguagem natural qualquer fossem teoremas, derivados a partir de axiomas composicionais e axiomas definidores da referência de cada type termo subsentencial. Ou seja, Davidson não só propunha não apenas revelar a forma lógica da linguagem, mas explicitar o algoritmo que nos permitiria dar a forma lógica de qualquer sentença da linguagem natural. Entretanto, a completa execução dessa proposta está além do alcance da própria filosofia; ela depende de um desenvolvimento na linguística que nos permita correlacionar - também de maneira algorítmica - as categorias gramaticais "genuínas" (isto é, as categorias gramaticais da gramática produzida pela melhor teoria linguística) e as categorias da lógica clássica. De qualquer forma, podemos deixar de lado qualquer problema para o projeto davidsoniano advindo desse aspecto. A maioria das teorias que estamos chamando aqui de "teorias semânticas" se contenta com muito menos: elas apenas pressupõem que somos capazes de traduzir de maneira eficiente tokens de sentenças de uma linguagem natural para a linguagem formal da lógica.
} 
verdade está circunscrito ao âmbito das ciências formais: um lógico ou matemático pode perfeitamente pressupor o conceito de sentido e de sinonímia em suas teorias. Mas isso é problemático para Davidson na medida em que ele quer tomar o valor de verdade verdadeiro como sendo o aspecto básico de todo o significado.

A necessidade de Davidson de ter de explicar de maneira não circular o que é uma tradução correta pode ser vislumbrada a partir de outra perspectiva: o operador bicondicional da lógica clássica (assim como os demais) é "fraco" demais para por si só ser capaz de nos dar uma lista de sentenças-T genuínas. Se buscarmos uma teoria tarskiana da verdade exigindo apenas que a forma geral de uma sentença-T seja satisfeita, então essa teoria terá, além das sentenças-T genuínas, sentenças-T "penetras” como “ 'A neve é branca' é verdadeiro se e somente se a grama é verde" e " “A neve é roxa' é verdadeiro se e somente se a grama é roxa"; e uma teoria tarskiana da verdade que aceitasse sentenças-T "penetras" não seria de nenhuma utilidade, uma vez que não nos informaria nada a respeito do significado das expressões nela envolvidas. Que a sentença usada no lado direito deva ser uma paráfrase da sentença mencionada do lado esquerdo é uma condição de existência acerca do que é uma sentença-T, utilizada como um "filtro" para que a lista de sentenças fornecida por uma teoria tarskiana da verdade nos informe sobre alguma coisa.

A resposta de Davidson para essa questão é que teorias tarskianas que contenham sentenças-T “penetras” são simplesmente infirmadas pela experiência, ao consideramos as regularidades envolvendo o comportamento linguístico dos sujeitos e circunstâncias do ambiente associadas a eles. Teorias tarskianas que contenham apenas sentenças-T genuínas, por outro lado, são aquelas empiricamente corroboradas. Ainda, as supostas sentenças-T de uma teoria tarskiana hipotética não são testadas uma a uma, mas em conjunto: o significado das expressões (e mesmo a estrutura dessas expressões, qual delas funciona como predicado, qual delas funciona como termo singular...) que constam numa teoria tarskiana da verdade para uma linguagem qualquer é determinado holisticamente (cf. DAVIDSON, 1991, Ensaio 9). Que “"A neve é branca’ se e somente se a grama é verde” não é uma sentença-T é evidenciado - entre inúmeras outras coisas - por exemplo, pelo fato de que os falantes do português estão muito menos propensos a proferir "A neve é branca" em situações onde eles estão diante de um gramado verde do que 
em situações em que estão diante de um solo nevado. ${ }^{33}$

Em realidade, a teoria do sentido de Davidson vem a ser exatamente uma teoria da interpretação (onde "interpretação" é entendido grosso modo como tradução): uma teoria que estipula os critérios norteadores para a elaboração de uma teoria tarskiana da verdade, formada apenas por sentenças-T genuínas. E a base de sua teoria da interpretação é o que ficou conhecido como princípio da caridade, o que nós devemos, enquanto estamos tentando entender o que um sujeito quis dizer com um determinado proferimento, é atribuir a esse sujeito as mesmas crenças que nós teríamos (ou que nós acharíamos razoável ter) dentro das circunstâncias em que o proferimento é feito. Supomos que nosso interlocutor tem as mesmas crenças que nós julgamos justificadas ou razoáveis naquelas circunstâncias e então supomos que os proferimentos que ele faz em tais circunstâncias expressam essas crenças. O sentido da sentença proferida é então pensado como sendo o mesmo que o sentido de uma sentença que na nossa linguagem expressa aquela crença (cf, DAVIDSON, 1991, Ensaio 9).

Um exemplo tomado emprestado de $\operatorname{Kirkham}$ (2003, p. 318) ajuda a compreender a importância do princípio. Suponhamos, nos moldes do experimento mental da tradução radical de Quine, que um antropólogo davidsoniano esteja visitando uma tribo que fala uma língua até então desconhecida e que ele deseje elaborar um esboço de teoria tarskiana da verdade para essa língua. Acompanhando atentamente as atividades realizadas pelos nativos, o antropólogo constata que quando os nativos vão tomar banho, eles tendem a dizer "bula krang" quando e somente quando a água está fria. Ele também nota que a expressão "bula" tende a ser proferida junto com outras que ele ainda não identificou quando há água por perto (por exemplo, ele nota que alguns nativos recebem uma moringa com água depois de pronunciar essa expressão, e também nota que apontam para cachoeira pronunciado) e que eles tendem a pronunciar (junto com outras expressões que ele não identifica) "krang" quando e apenas quando faz frio. Nosso antropólogo então elabora a hipótese de que “"Boola krang” é verdadeira se e somente se a água está fria” é uma sentença-T para a língua dos nativos. Mas como isso se dá?

Ora, o antropólogo faz isso projetando uma série de crenças que ele próprio

\footnotetext{
${ }^{33}$ Dentre as inúmeras outras evidências estaria o fato de que os sujeitos estão mais dispostos a dizer "branco" apontando para coisas brancas, mas não para coisas com outras cores, "neve" apontando para uma foto com um pico nevado, neve acumulada no chão, etc.
} 
tem nos nativos. Ele sente a água fria do banho e então forma a crença de que a água está fria, e pensa que por esse mesmo mecanismo sensorial os nativos formam suas crenças. Mas não só isso: ele crê que, tal como nós fazemos, é uma boa estratégia comunicativa usar um mesmo tipo de palavra com o mesmo significado; que, como nós os fazemos, usamos a linguagem pra descrever a realidade, e quando fazemos isso normalmente nós expressamos por meio da linguagem aquilo que nós acreditamos ser verdadeiro. De fato, o nosso antropólogo pressupõe que ele e os nativos compartilham quase todas as crenças que podem, dentro daquele contexto, ser as mesmas.

Exatamente por estar propondo uma teoria extensionalista, Davidson também teria de oferecer, como o Tractatus oferecia, uma redução sem resíduo dos vários tipos de discurso intencional ao discurso puramente extensional do cálculo clássico de predicados. Mas Davidson só aponta um caminho nessa direção para algumas poucas expressões do discurso semântico, como "sentido" e "querer dizer" (introduzir referência), e para algumas noções do discurso intencional como crença e ação (introduzir referência). Ficamos no escuro em relação a como analisar logicamente o discurso modal sobre necessidade e possibilidade, sobre contrafactuais e causalidade, e mesmo o discurso lógico-matemático. ${ }^{34}$

Independentemente de quaisquer desses aspectos, eu penso que há ainda duas grandes objeções que se pode fazer em relação ao projeto extensionalista de Davidson. A primeira é que os princípios interpretativos não são suficientes para evitar a indeterminação semântica, para a qual Quine já havia chamado atenção no seu experimento mental da tradução radical. É possível que duas ou mais teorias tarskianas da verdade para um sujeito, inconsistentes, e, portanto, incompatíveis entre si, maximizem igualmente bem a verdade (e a coerência e a racionalidade) para o conjunto de crenças atribuído a esse sujeito. Davidson reconhece esse ponto, considerando, entretanto como pouco problemático (cf. DAVIDSON, 1991, Ensaio 10). No entanto, como veremos no próximo capítulo, esse tipo de indeterminação é capaz de gerar uma forma especialmente aguda de ceticismo, que não é facilmente

\footnotetext{
34 O tratamento que Wittgenstein dá a esses domínios discursivos no Tractatus não é muito auspicioso do ponto de vista do fisicalismo e do realismo científico que a abordagem davidsoniana parece promover. O Tractatus nega que haja qualquer outra necessidade que não seja a necessidade lógica, e nega status cognitivo a enunciados matemáticos, favorecendo uma visão francamente instrumentalista do discurso científico em geral.
} 
respondível.

Em segundo lugar, a teoria da interpretação de Davidson parece sofrer do mesmo tipo de autofagia da qual sofria a doutrina do Tractatus. Os princípios interpretativos, ao que parece, não podem ser eles próprios analisados em termos de uma teoria tarskiana da verdade, ou seja, não podem ser analisados extensionalmente. Eles desempenham o papel de normas necessariamente pressupostas a toda e qualquer análise lógica, não podendo eles próprios aparecer na forma de sentenças-T. ${ }^{35}$ Assim, princípios interpretativos não podem ser considerados verdadeiros e nem mesmo significativos à luz do próprio critério de significação davidsoniano. Nesse ponto, parece que resta ao davidsoniano somente tentar resgatar algo como a distinção tractariana entre dizer e mostrar (inserir referência), declarando assim pomposamente: “os princípios interpretativos são absurdos indizíveis, mas se mostram na própria construção de uma teoria tarskiana da verdade para uma linguagem."

\subsubsection{Intensionalismo clássico I: mundos possíveis}

Por ser uma espécie de "leito de Procrusto" para as linguagens naturais, o extensionalismo é preterido por muitos daqueles que poderíamos denominar teóricos clássicos. Eles consideram o intensionalismo como teoricamente inevitável, e muitos deles vislumbram nas semânticas de mundos possíveis a melhor alternativa para explicar o discurso intensional. Assim como Davidson havia tomado a teoria dos modelos de Tarski como o paradigma de aparato formal para sua teoria semântica extensional, muitos tomaram os modelos de mundos possíveis de Kripke como base formal para suas teorias semânticas intensionais.

Os modelos de Kripke funcionam adicionando uma "camada extra" na lógica clássica extensional, trazendo a ideia de mundos possíveis para definir os operadores lógicos modais. Ao invés de, como na semântica formal tarskiana, definir verdade (por meio de cláusulas que produzem uma lista de sentenças verdadeiras para uma estrutura), na semântica formal "kripkeana" passamos a definir, de um modo análogo, verdade em um mundo possível. Do ponto de vista

\footnotetext{
35 Se os princípios interpretativos, de caráter normativo, são analisados no logiquês do cálculo clássico de predicados, então eles parecem se tornar imediatamente supérfluos, uma vez que eles são invocados exatamente para evitar a presença de sentenças-T "penetras" nas teorias tarskianas da verdade para as linguagens naturais, permitidas em função da "fraqueza" do bicondicional material.
} 
estritamente formal, isso significa ter várias interpretações de sentenças, termos singulares e predicados de uma linguagem, em vários domínios de discurso distintos (cf. GIRLE, 2009, pp. 114-116), ao invés de uma única interpretação em apenas um domínio de discurso, como nas lógicas extensionais. De um ponto de vista informal, um mundo possível pode ser concebido sucintamente como representando "configurações" da realidade, de modo que nós vivemos em uma certa configuração (na qual, por exemplo, o Liverpool foi campeão do Mundial de Clubes em 2019), mas muitas outras configurações são possíveis, mais ou menos semelhantes às nossas (uma praticamente idêntica à nossa, com a diferença de o Liverpool não tivesse sido campeão mundial em 19 ; outra muito diferente, na qual os oceanos são povoados por polvos gigantes).

Lógicas modais foram utilizadas para explicar praticamente todos os discursos intensionais imagináveis, incluindo discursos intencionais (lógicas doxásticas e epistêmicas), discurso moral (lógicas deônticas) e temporal (que já foi mencionado, inclusive). Mas eu penso ser seguro dizer que nenhuma abordagem foi filosoficamente mais impactada pelo advento das semânticas de mundos possíveis do que aquelas envolvendo as modalidades aléticas, que definem necessariamente verdadeiro como verdadeiro em todos os mundos possiveis e possivelmente verdadeiro como verdadeiro em ao menos um mundo possível. A lógica modal alética, desse modo, costuma ser considerada como a base para explicar a intensionalidade própria das linguagens naturais em geral.

A intensão de um predicado é dada por uma função que vai de mundos possíveis a conjuntos de objetos que satisfazem aquele predicado naquele mundo, ou seja, que são a extensão daquele predicado naquele mundo. Por exemplo, a função que dá a intensão do predicado "(ser) vermelho" vai a cada mundo possível e em cada mundo possível forma um conjunto das coisas vermelhas naquele mundo. A intensão de um termo singular é dada por uma função que vai de mundos possíveis a objetos que fazem parte do domínio de discurso daquele mundo. Um termo singular é um designador rígido se essa função seleciona o mesmo objeto em todos os mundos possíveis nos quais ele está presente; ou é um designador frouxo se o objeto que esse termo singular denota varia de um mundo possível para outro. Nomes próprios são normalmente considerados como designadores rígidos pelos intensionalistas dos mundos possíveis (é imaginável que Aristóteles tivesse sido médico como o seu pai, ao invés de filósofo, e ainda assim continuasse sendo o 
nosso Aristóteles) $)^{36}$ enquanto que descrições definidas são consideradas designadores frouxos (nesse mundo possível no qual Aristóteles não se tornou filósofo, a descrição definida "o mais importante discípulo de Platão" seria satisfeita por outra pessoa que não Aristóteles). Por sua vez, intensões de sentenças (enunciados) são dadas por uma função que vai de mundos possíveis (da totalidade dos mundos possíveis) a mundos possíveis (o subconjunto de mundos possíveis nos quais a sentença é verdadeira).

Agora, um ponto de relevância filosófica é estabelecer o que exatamente são mundos possíveis, e nesse aspecto podemos dividir os intensionalistas dos mundos possíveis em dois grandes grupos: atualistas e possibilistas.

Segundo os atualistas, o discurso sobre mundos possíveis é apenas uma façon de parler: apenas o nosso mundo atual existe realmente, e mundos possíveis normalmente são tomados como sendo apenas ficções, construídas a partir das coisas que compõem a nossa realidade e através da linguagem que nós utilizamos para descrevê-la. Do ponto de vista lógico, os mundos possíveis da semântica kripkeana são eles mesmos analisados em termos de sentenças maximais consistentes, isto é, longas conjunções de sentenças envolvendo objetos do mundo real tal que elas não contenham nenhuma contradição (cf. NEY, 2014, pp. 202-203). Por exemplo, há pelo menos uma sentença maximal consistente contendo o enunciado "Krakens habitam os oceanos", mas não há nenhuma sentença maximal consistente contendo "Todos os números pares são ímpares".

Por outro lado, possibilistas interpretam a expressão "mundos possíveis" literalmente. Eles sustentam que existem múltiplos universos - "regiões do espaçotempo maximamente conectadas" (LEWIS apud NEY, 2014, p. 196), cada qual sendo um objeto concreto sendo causalmente inacessíveis entre si; o nosso mundo, o mundo real é apenas um entre vários, infinitos mundos possíveis. Se o enunciado "Krakens habitam os oceanos" é possivelmente verdadeiro, então existe pelo menos um mundo possível - certamente semelhante ao nosso em muitos aspectos - em que os mares do nosso planeta são habitados por cefalópodes gigantescos capazes de agarrar grandes navios com seus tentáculos. Aliás, a intensão (o conteúdo) do

\footnotetext{
${ }^{36}$ Cf. KRIPKE, 1980. Intensionalistas dos mundos possíveis também consideram que predicados também podem se comportar como designadores rígidos: por exemplo, os chamados tipos naturais (elementos químicos, substâncias químicas, espécies de seres vivos) (cf. PUTNAM, 1975 Vol 2, cap. 12).
} 
enunciado "Krakens habitam os oceanos" é de fato tido como o conjunto de mundos possíveis no qual o enunciado é verdadeiro.

O trade off envolvendo disputas entre abordagens atualistas e possibilistas é basicamente o mesmo que em qualquer discussão envolvendo ontologia: ganho explicativo x parcimônia ontológica. O possibilista (realista modal genuíno) oferece uma poderosa ferramenta de análise dos contrafactuais ${ }^{37}$ e da causalidade, mas, uma vez que ele parte de uma ontologia superpovoada, a ele incumbe o ônus da prova de que o atualista (chamado de realista modal ersatz) é ou bem inconsistente ou ao menos não é capaz de tudo o que ele - possibilista - consegue explicar (cf. NEY, 2014, pp. 193-206). Há, entretanto, objeções a aplicação da semântica de mundos possíveis para as linguagens naturais (tomando a modalidade alética como básica) que atingem ambos os lados. Em geral, eles explicam a diferença e a identidade de significados entre duas ou mais expressões apelando para uma diferença ou identidade de intensões. Por exemplo, que as expressões "cordados" e "renatos" não tem o mesmo significado é explicado pelo fato de que, apesar de eles terem a mesma extensão no mundo real, eles têm extensões diferentes em pelo menos alguns mundos possíveis (sejam eles universos causalmente desconectados uns dos outros ou sentenças maximais consistentes). Agora, consideremos termos e sentenças da matemática; dado que a matemática lida com verdades necessárias a priori, uma semântica de mundos possíveis tomaria predicados como ‘equilátero' e 'equiângulo' como sinônimos, uma vez que a extensão desse predicado é a mesma em todos os mundos possíveis. No entanto, as expressões não são obviamente sinônimas: é inteiramente aceitável que alguém compreenda ambas as expressões (a pessoa é capaz de aplicar o predicado 'equiângulo' e 'equilátero' a todas a somente as coisas que são satisfeitas por esses predicados), e ainda, não saber que todas as figuras equiláteras têm ângulos iguais. A relação de sinonímia é, digamos

\footnotetext{
37 Segundo Ney (2014, p. 198), realistas modais tomam um enunciado contrafactual como verdadeiro se o condicional que ele expressa é verdadeiro nos mundos possíveis mais semelhantes ao mundo atual. Tomemos como exemplo o contrafactual "Se o Liverpool não tivesse vencido a Liga dos campeões em 2019, não teria sido o campeão mundial de 2019". Há todo um conjunto de mundos possíveis que em tudo se assemelham ao nosso mundo atual, com exceção de o Liverpool não ter sido campeão da Champions em 2019 e alguns outros fatos que necessariamente seriam alterados para que isso fosse verdade (por exemplo, outro time seria o campeão europeu daquele ano). Esse conjunto de mundos possíveis corresponde exatamente ao conjunto dos mundos "mais semelhantes ao mundo atual". Agora, a verdade do contrafactual consiste no fato de que, em nenhum desses mundos o Liverpool é campeão mundial (porque nesses mundos possíveis o mundial de clubes de 2019 ocorre no mesmo lugar que no mundo atual, as regras de qualificação para esse torneio são as mesmas, etc).
} 
assim, ainda mais "fina" que as intensões.

Uma outra objeção, colocada por Lycan (2000, pp. 156-157), diz respeito à questão da compreensão linguística. Um sujeito compreender uma sentença 's' consiste em ele manter uma espécie de relação (a relação de entendimento) com um conjunto de mundos possíveis (pelo menos no caso dos realistas modais genuínos, isso significa ter algum tipo de relação com universos paralelos), aqueles nos quais a sentença é verdadeira. Mas esse tipo de explicação, além de ser ontologicamente extravagante, não diz nada a respeito da manifestação do entendimento através do comportamento dos sujeitos.

\subsubsection{Intensionalismo clássico II: realismo proposicional}

Outro caminho para o intensionalista foi apontado (e seguido) pelo próprio Frege, considerando-se a fase mais madura de sua obra (a partir de 1890). Frege concebia proposições (Gedanke, "pensamento") - o sentido ou conteúdo de um enunciado como um tipo de entidade abstrata - fora do espaço-tempo e independente da mente, e por isso intersubjetivamente acessível, pertencente a um "terceiro domínio" - além dos domínios natural e mental (FREGE, 1997, pp. 333337). Russell (cf. 1998, caps. 9 e 10) e Moore (cf. 1953/1962, cap. 3) igualmente se inserem na tradição do realismo proposicional.

Proposições - concebidas dessa maneira como entidades abstratas - são invocadas para cumprir praticamente todos os papéis teóricos que justificam uma ontologia das intensões: são os objetos "genuínos" 38 de atos e estados intencionais (crença, desejo, dúvida etc), e como isso, a denotação orações subordinadas envolvendo "cláusulas que"; e são o sentido ou conteúdo dos enunciados, expressos por sentenças, e por isso são também os portadores primários das propriedades lógico-semânticas (implicação, compatibilidade, incompatibilidade, necessidade, possibilidade, verdade e falsidade ${ }^{39}$ ) e os objetos diretamente envolvidos em relações de sinonímia - o que representa o grande ganho explicativo em relação ao

\footnotetext{
${ }^{38}$ Aqui fazemos um contraste com os intensionalistas dos mundos possíveis, que normalmente tem inclinação nominalista e não trata esses objetos como entidades "autônomas", mas como colocamos acima, como conjuntos de mundos possíveis.

${ }^{39}$ Como já mencionamos (cf. n11.), Frege não tomava verdade e falsidade como predicados expressando propriedades, mas como objetos lógicos. Estamos aqui, entretanto, seguindo quase que a totalidade dos realistas proposicionais ao tratá-las desse modo.
} 
intensionalismo de mundos possíveis. Os predicados 'equilátero' e 'equiângulo', assim, não seriam sinônimos, pois estariam associados a diferentes universais.

Assim como no caso do intensionalismo dos mundos possíveis, há uma série de controvérsias entre os próprios realistas proposicionais. A principal delas, poderíamos dizer, envolve a questão da composição da proposição: se elas possuem partes componentes, e se possuem, qual seria a sua natureza (cf. LOUX, 2006, pp. 129-130; SPEAKS, 2020). A resposta dominante no realismo proposicional é que proposições resultam da articulação entre universais - entendidos aqui como tendo a mesma natureza de entidade abstrata que as próprias proposições, e que seriam expressos por termos funcionais em uma notação lógica - e objetos, que seriam denotados por termos singulares. Apesar de Frege ter considerado os universais (funções) como sendo a denotação de termos funcionais, normalmente se considera as extensões dos universais como sendo a sua referência e os próprios universais como estando no nível semântico intensional - isto é, com sendo eles próprios o conteúdo ou sentido dos termos funcionais (cf. RUSSELL, 1903/2010, pp.48-50 e pp. 68-70).

Obviamente, todo poder explicativo advindo de um realismo proposicional vem com um alto custo: o de ter de explicar como é possível a apreensão de tais entidades abstratas causalmente inertes por sujeitos inteligentes habitantes de um domínio material, espaço-temporal. Afinal, é na apreensão dessas entidades que consiste na posse de estados e a realização de atos intencionais, incluindo a própria compreensão linguística. O ponto aqui não é apenas que, como no caso do intensionalista dos mundos possíveis, nada se diga a respeito da manifestação da compreensão linguística (e da própria posse de estados intencionais) na teoria do sentido. O ponto aqui é que a compreensão passa a ser algo totalmente misterioso: entidades abstratas aqui não são apenas entidades teóricas com as quais não temos nenhum acesso, mas muito pelo contrário, são coisas em relação as quais teríamos supostamente um dos mais diretos dos acessos (cf. RUSSELL, 1912;1998, caps 5, 9 e 10).

Considerando que o realismo proposicional nos dá não apenas como ontologia um céu platônico superpovoado com entidades abstratas, como também nos deixa com um mistério acerca de como é possível termos um acesso direto a essas entidades, aos seus defensores cabe o pesado ônus de mostrar que não há 
alternativa viável para explicar o fenômeno da significação linguística e da intencionalidade.

\subsection{Realismo, verdade e teorias do significado}

Até agora tivemos a oportunidade de ver como várias questões de natureza metafísica e epistemçógica são sistematicamente abordadas ao discutirmos quais devem ser as expressões da característica universal de uma teoria semântica ("deve haver operadores intencionais?"), bem como qual a natureza do valor semântico desses termos (“qual a referência dos predicados?"). Mas não falamos até então de um debate fundamental na metafísica e na epistemologia que igualmente ganhou um tratamento sistemático no âmbito da semântica: o debate entre realismo e não realismo, transversal a uma série de questões (do problema dos universais ao problema do mundo exterior) e áreas particulares da filosofia (da metafísica e epistemologia a ética e a estética).

\subsubsection{Realismo e suas marcas}

Acredito que uma das definições mais esclarecedoras para o "realismo em geral" disponíveis na literatura seja oferecida por Wright, na introdução da sua coletânea de artigos Realism, Truth and Meaning (1987). Wright começa sua caracterização do realismo (qualquer que seja o domínio ao qual ele seja aplicado) afirmando que ele é uma espécie de meio termo entre modéstia e presunção teóricas (ibidem pp.12): a "modéstia" consiste em pensar que há uma realidade objetiva, independente de nossas mentes e de nossas descrições. A presunção, por outro lado, consiste em assumir que nossas capacidades cognitivas são - em condições favoráveis (e isso deve ocorrer na maior parte dos casos) - suficientes para nos permitir fazer uma descrição acurada da realidade. Nos outros extremos desse espectro estão as posições adversárias ao realismo. No extremo da modéstia, está o ceticismo, negando que na maioria dos casos (na situação limite, em todos os casos) nossas capacidades cognitivas nos permitam acessar a realidade tal como ela é (ibidem, p.2). Por outro lado, no extremo da presunção está o idealismo, estabelecendo que a natureza dos nossos poderes cognitivos e conceituais determinam os limites da própria realidade (ibidem, p. 2).

Essa caracterização espectral das posições tem para mim inegavelmente um sabor moral. Almejamos, prima facie, o realismo em nossas teorias. $\mathrm{O}$ realismo 
representa uma resposta prudente e virtuosa à questão do nosso acesso cognitivo à realidade, estando mais ou menos distante dos "vícios" opostos: a extrema modéstia do cético, que nega esse acesso, e a extrema pretensão do idealismo, que colapsa o exercício da capacidade cognitiva com o próprio acesso. Nossas intuições são fortemente realistas e, na ausência de um bom argumento contra o realismo em uma determinada área, não há razão alguma para nos movermos em direção a qualquer um dos dois polos desse espectro (uma vez que Wright tem fortes pendores antirrealistas, não é muito claro se ele endossa ou não a presunção prudencial de virtude do realismo).

A ideia de que a posição realista envolve gradações foi bem desenvolvida, embora de maneira um tanto quanto fragmentária, ao longo da obra de Wright. De acordo com o autor, não haveria um, mas vários traços característicos do realismo, com alguns sendo mais "fortes" do que outros ${ }^{40}$, e podendo eles serem ou não implicados uns pelos outros. Apresentamos aqui três dos "tipos" de realismo definidos por Wright: objetividade da verdade (OV), independência do juízo (IJ) e objetividade do juízo $(\mathrm{OJ})$ - ressaltando que há uma gradação entre eles, de forma que OV implica IJ, IJ implica OJ, mas não o contrário. Os três tipos, e a relação de gradação entre eles, podem ser explicados em articulação com os enunciados que Wright denominou equações básicas. As equações básicas de Wright nada mais são do que enunciados que equiparam verdade e justificação máxima relativamente a um enunciado ' $p$ ', de modo que ' $p$ ' pertença a um certo domínio discursivo. A forma geral de uma equação básica, segundo Wright, consiste em

$$
\mathrm{p} \leftrightarrow\left(\mathrm{C}_{\mathrm{s}} \rightarrow \mathrm{R}_{\mathrm{s}}\right)
$$

onde ' $\mathrm{C}_{\mathrm{s}}$ ' representa as condições padrão nas quais um sujeito está maximamente justificado (tanto condições relativas ao ambiente natural e social quanto a condições relativas a estados do próprio sujeito, como o bom exercício de habilidades perceptuais, por exemplo) em julgar que p; 'Rs', por sua vez, é a própria resposta do sujeito, manifesta no proferimento de 'p' ou na crença de que p, por exemplo (WRIGHT, 1994, pp. 108-109). A título de ilustração, algo como $\mathrm{x}$ é um quadrado $\leftrightarrow$ ((s é um sujeito com capacidades visual normais e x está iluminado etc. $) \rightarrow($ x parece quadrado a s))

\footnotetext{
${ }^{40}$ Em realidade Wright não explicita nem que há relações de implicação entre as marcas do realismo nem que uma pode ser "mais forte" que outra; esta é uma assunção minha.
} 
seria uma equação básica se tivéssemos o enunciado "x é um quadrado" como 'p'. O grau de realismo que assumimos em relação a um 'p' é definido ao considerarmos qual lado do bicondicional de uma equação básica é o mais fundamental, isto é, qual lado tem status de explanans e qual lado tem status de explanandum, ao considerarmos se há uma tal equação básica para 'p', e que restrições nós devemos impor as condições padrão $\mathrm{C}_{\mathrm{s}}$.

Se admitimos a possibilidade de, em princípio, não haver uma tal equação básica para um enunciado relativo a um certo domínio discursivo $\mathrm{D}$, então assumimos a objetividade da verdade em relação a D. OV consiste precisamente na tese de que há (ou pode haver) enunciados inteligíveis em relação aos quais o seu valor de verdade seja transcendente às nossas melhores justificações. Candidatos óbvios a enunciados cuja verdade seja transcendente a melhor justificação são os enunciados teológicos e enunciados matemáticos para os quais não há um método de prova estabelecido (conjectura de Goldbach, por exemplo). Para essa forma mais forte de realismo, que haja certas equações básicas é uma mera "concessão" da realidade; não definimos, mas descobrimos que em algumas situações nossas melhores evidências para acreditar em $\mathrm{p}$ garantem a verdade de $\mathrm{p}$. Notemos, de qualquer modo, que a expressão "transcendente a melhor justificação" pode ser interpretada também de formas mais ou menos fortes (cf. 3.2 abaixo). Virtualmente, qualquer domínio pode ser considerado como contendo enunciados transcendentes a melhor evidência: domínios envolvendo quantificação sobre domínios infinitos, estados mentais de outras pessoas, passado e futuro, e mesmo objetos físicos.

A independência do juízo é detalhadamente definida por Wright em seis cláusulas que envolvem as equações básicas (1994, pp.111-124), mas creio que essa marca do realismo pode ser bem resumida ao estabelecermos que, se um domínio de enunciados possui IJ, então o lado esquerdo de uma equação básica tem prioridade explicativa sobre o direito. A ideia de Wright é que IJ forneça um critério que nos permita distinguir entre propriedades primárias e secundárias. Considerando, por exemplo, um predicado de cor, Wright afirma que sua extensão não pode ser determinada independentemente dos nossos juízos sobre cor em condições objetiva e subjetivamente adequadas definidas a priori. Nós definimos um objeto como sendo vermelho se ele parece vermelho a um observador em condições padrão, e apenas depois, através de investigações empíricas, descobrimos uma outra maneira de determinar a extensão desse predicado (por exemplo, pelo 
comprimento de onda refletida superfície dos objetos vermelhos). Mas o mesmo não ocorre com os predicados de forma geométrica: a extensão do predicado "quadrado" é definida independentemente de os sujeitos aplicarem ou não esse predicado em determinadas circunstâncias: uma figura tem a forma de um quadrado se e somente se ela tem quatro lados iguais, formando ângulos internos de $90^{\circ}$. Nós descobrimos que somos capazes de identificar quadrados em certas condições, mas, que algo parece vermelho a um sujeito em determinadas situações é uma verdade a priori e analítica.

Finalmente, objetividade do juízo é atribuída a enunciados cujo conteúdo é "genuinamente factual" (WRIGHT, 1987, p.6), e são verdadeiros ou falsos em função da subsistência ou não de estados de coisas que podem ou não ser objeto da cognição humana (WRIGHT, 2001, p. 62). Atribuir OJ a um domínio discursivo “juízo-dependente”, como Wright faz para cores, é uma maneira de conservar um mínimo de realismo para os enunciados desse domínio. Tendo em vista as equações básicas, isso consiste em exigir que as condições padrão que aparecem como antecedente do condicional do lado direito sejam bem especificadas e não sejam triviais. Suponhamos, por exemplo, um topo nevado de uma montanha muito alta, que, por questões de posição e iluminação, sempre apareça rosado para os nativos que habitam um vale. Gerações de nativos podem ter pensado que o topo da montanha era coberto por uma matéria rosa ao invés de neve, mas isso não torna verdadeiro que aquela neve fosse rosa, ou que aquela matéria não fosse neve por ser rosa. OJ é uma espécie de versão muito atenuada de OV: ela estabelece a possibilidade de que a verdade dos enunciados seja transcendente a toda evidência atual, disponível aos falantes competentes da linguagem em uma determinada situação. É OJ que dá sentido a ideia de que podemos estar errados ou enganados sobre a realidade.

\subsubsection{Objetividade da verdade, ceticismo e teoria semântica}

Aderir à OV significa adotar um grau elevado de realismo, pelo menos dentro de um certo domínio discursivo. A maioria dos autores denominados "realistas" na literatura endossa OV de quase maneira universal - normalmente tendo como única exceção os enunciados mentalísticos em $1^{\mathrm{a}}$ pessoa e no presente, onde a identidade entre verdade e melhor evidência é garantida por algum princípio de infalibidade perceptual envolvendo objetos mentais interiores. Entretanto, essa 
posição também é, tradicionalmente falando, a mais vulnerável a ataques céticos. É a adesão à $\mathrm{OV}$ no âmbito do discurso psicológico em $3^{\mathrm{a}}$ pessoa e do discurso sobre objetos físicos independentes da mente que abre espaço para o problema cético das outras mentes e do mundo exterior, respectivamente. Alguns realistas levam tais problemas a sério, fazendo da sua solução um dos principais objetivos de sua empreitada filosófica (Descartes é o paradigma aqui), enquanto outros, no outro extremo, dão de ombros e simplesmente os ignoram (realistas do senso comum); a maioria dos realistas (v.g., Locke, Russell), entretanto, se situa entre esses dois extremos. O que todos eles compartilham é um certo insucesso em lidar com essas objeções céticas, de um modo ou de outro.

Deixando de lado objeções céticas mais clássicas, Dummett ofereceu mais recentemente um argumento geral contra OV (que Dummett toma como sendo mais ou menos equivalente ao próprio realismo) tendo em vista suas implicações na seara da teoria semântica. Tal argumento é conhecido na literatura filosófica como argumento da manifestação, e no presente trabalho apresentamos uma versão do argumento reformulada por Wright. A ideia básica é a de que o entendimento que os sujeitos tem de um enunciado (e das suas expressões subsentenciais) se manifesta em um conjunto de habilidades práticas envolvendo comportamentos verbais e não verbais. Wright identifica quatro habilidades características do entendimento que um sujeito possui a respeito de um enunciado:

(a) habilidade de reconhecimento - e.g., o sujeito sabe que algo é salgado colocando a substância na boca, ou sabe que a bola é verde observandoa sob a luz do sol;

(b) capacidade de avaliar evidência a favor e contra a verdade do enunciado, bem como avaliar se há qualquer evidência;

(c) domínio das relações inferenciais das quais tal enunciado participa - i.e., de que enunciados ele pode ser inferido e quais enunciados ele implica (considerando hipóteses auxiliares, ou também um contexto ceteris paribus); e

(d) capacidade de atribuição de atitudes proposicionais envolvendo o conteúdo do enunciado, tanto em $1^{\mathrm{a}}$ quanto em $3^{\mathrm{a}}$ pessoa - ou seja, o sujeito sabe manifestar atitudes intencionais envolvendo esse conteúdo, e sabe além disso reconhecer tais atitudes em outros sujeitos; 
Pois bem, se o realista estiver correto, então é possível que um sujeito compreenda um enunciado qualquer de um dado domínio discursivo sem que ele possa ter, em princípio, a habilidade (a). Com efeito, o que o endosso de OV em um domínio discursivo implica é ou que (a) não é uma condição necessária para o entendimento de um enunciado desse domínio ou que o próprio entendimento aí é impossível.

Uma vez que parece absurdo o realista negar a própria possibilidade de entendimento de um enunciado significativo, o que resta ao realista é rejeitar (a) como condição necessária para o entendimento e buscar, ao invés disso, um tipo de explicação da compreensão em termos da ocorrência de estados mentais interiores, dissociando o entendimento de qualquer manifestação comportamental. Essa rota, entretanto, é problemática não apenas por fazer uma teoria do sentido explicar menos do que deveria, ao rejeitar que haja uma conexão entre comportamento e compreensão. Ela é problemática também por trazer para dentro da teoria semântica o ceticismo sobre outras mentes, tornando a compreensão linguística um fenômeno publicamente inescrutável.

É claro que se um teórico do significado se sentir à vontade com uma ontologia dualista de substância, ele pode aceitar tranquilamente essa consequência, embora nós suponhamos que poucos hoje estejam nessa posição. Por outro lado, fenomenalistas também não precisam se preocupar com a dicotomia interno/externo, uma vez que eles nem sequer a admitem. Agora, todo o ponto do argumento é o de que, se quisermos nos manter dentro de uma visão de mundo fisicalista, onde tudo é intersubjetivamente acessível, e exigir, além disso, que toda a compreensão linguística tenha uma manifestação comportamental, então devemos rejeitar a própria possibilidade de termos verdades transcendentes à evidência.

Notemos que, assim como há formas extremamente fortes de realismo, há formas extremamente fortes de antirrealismo. O que é ser ou não uma verdade transcendente ao reconhecimento é algo que também está em discussão. Há diferentes concepções do que isso quer dizer. A depender de como se nega OV, pode-se negar também IJ e OJ. Por exemplo, se pensamos o enunciado "Choveu na cidade do Rio de Janeiro no dia 10 de julho de 1820" como tendo seu valor de verdade transcendente à evidência, por não haver nenhuma evidência à disposição (nenhum relato de jornal, nenhum registro meteorológico paroquial), então estaríamos assumindo uma forma extrema de antirrealismo - que considera que se não há evidência confiável atualmente disponível a respeito do valor de verdade de 
um enunciado, então ele é considerado "transcendente à verificação".

Mas, dado que nós almejamos ser tão realistas quanto possível, penso que o melhor, diante do argumento da manifestação, é fazer uma concessão mínima ao idealismo (antirrealismo), escorregando levemente em direção a ele para evitar um movimento ainda maior na direção oposta, a do ceticismo. Essa concessão mínima envolve, ao menos por enquanto, rejeitar a OV sem rejeitar OJ, e sem "secundarizar" o nosso léxico (isto é, pensar que todos os enunciados são juízodependentes). Assim, queremos uma concepção de verdade não transcendente à melhor justificação que seja o menos antirrealista possível. E o mínimo que temos que fazer para rejeitar OV é simplesmente negar que haja quaisquer verdades que em princípio sejam transcendentes à evidência; para isso, basta dizer que, para qualquer expressão significativa de uma linguagem, sua compreensão por um sujeito deve ser sempre manifestável em termos de comportamentos. Para quaisquer enunciados de uma linguagem qualquer, seríamos em princípio sensíveis à sua verdade, ainda que em uma situação atual eventualmente não houvesse nenhum meio de se estabelecer com segurança o seu valor de verdade (retomando o exemplo do parágrafo anterior, a ausência de registro histórico confiável para estabelecermos o valor de verdade do enunciado em questão não deve torná-lo transcendente à verificação; nós sabemos exatamente quais experiências perceptuais o tornariam verdadeiro, e isso é o que importa aqui).

\subsubsection{Objetividade da verdade, teorias clássicas e representacionismo}

$\mathrm{O}$ argumento da manifestação nos leva a buscar uma teoria do significado que não nos comprometa com $\mathrm{OV}$. Mas qual a relação entre $\mathrm{OV}$ e as teorias clássicas do significado que apresentamos? OV implica ou preclui algumas das marcas características que usamos para definir uma teoria clássica?

Os textos do artífice desse argumento - Dummett - sugerem que abrir mão da concepção de verdade (possivelmente) transcendente à justificação nos impele em direção a uma abordagem intuicionista da lógica, e com isso, a uma rejeição da lógica clássica como sendo a base para uma característica universal.

Entretanto, uma vez que, como sustenta Wright, a diferença entre as posições realistas e não realistas é mais bem entendida de maneira graduada, a associação direta entre $\mathrm{OV}$ e a lógica clássica seria um movimento apressado. De fato, como destacamos acima, não apenas o realismo possui outros traços além de 
OV - o que nos permite pensar na dictomia realismo x antirrealismo como um espectro - como também a própria noção de verdade transcendente à evidência admite um tratamento nuançado. Subscrevendo essa abordagem proposta por Wright, temos considerado inclusive as teorias verificacionistas - francamente hostis a $\mathrm{OV}$ - como teorias clássicas - e como teorias consistentemente comprometidas com a lógica clássica (cf. AYER, 1936;1952).

Mais discreta é a relação entre OV e o representacionismo. Embora não haja relação de implicação direta entre as duas posições, há uma afinidade mútua. O representacionismo das teorias clássicas trata a verdade não apenas como uma noção representacional, mas como a noção representacional básica; qualquer noção normativa epistêmica que deva integrar o maquinário de uma teoria do significado deve vir como uma camada a ser sobreposta a camada das noções representacionais. Por outro lado, admitir OV é necessariamente abrir um fosso entre estar justificado ou habilitado a julgar que $\mathrm{p}$ e a própria verdade de $\mathrm{p}$; e isso costuma funcionar como uma motivação para tratar a verdade - em oposição a qualquer noção explicitamente epistêmica ou normativa - como a noção fundamental em uma teoria do significado. O representacionismo e OV são posições que se costumam se apoiar mutuamente.

Ao combinarmos o representacionismo com a tese de que a verdade pode ser transcendente a toda evidência possível, temos um arcabouço da concepção de semântica dominante, tanto na tradição quanto atualmente. Essa concepção assume uma espécie de "ponto de vista de Deus" acerca da realidade. Ela toma as coisas e os fatos da realidade tal como eles são, por um lado, e as representações que fazemos, quer por meio da linguagem, quer por meio de imagens mentais, por outro lado, e então questiona se nossas representações são fiéis ou não aos fatos no mundo que elas pretendem representar. As representações que fazemos dos fatos podem ser úteis, mas ainda assim inacuradas do "ponto de vista divino" - como um mapa que desenhamos de improviso para mostrar a alguém como ir de um ponto a outro da cidade é útil para nós, porém ainda assim inacurado para representar a cidade. Desse modo, a semântica deveria estabelecer os critérios necessários e suficientes para que uma representação pode ser boa "do ponto de vista divino", e deixar em segundo plano os critérios necessários e suficientes para que uma representação seja boa "do nosso ponto de vista".

Evidentemente, o argumento da manifestação não é de modo algum um argumento direto contra o representacionismo, mas é pelo menos um argumento 
contra o tipo paradigmático de representacionismo. Além disso, as abordagens de estirpe verificacionista (cf. AYER, 1936;1952), que costumam se apresentar como alternativa antirrealista de representacionismo, são notadamente assoladas por argumentos contrários ao fenomenalismo metafísico associado a esse tipo de abordagem. Teríamos, assim, uma motivação inicial para buscarmos uma abordagem em teoria do significado que se contrapusesse ao próprio representacionismo. $\mathrm{O}$ inferencialismo desponta exatamente como forte candidato a ser uma boa alternativa, invertendo a ordem de prioridade explicativa e tomando a representação como algo a ser explicado em função de padrões normativos inferenciais. 


\section{O problema de seguir uma regra}

\subsection{Teoria fundacional do significado e ceticismo semântico}

Em 2.2 introduzimos a noção de teoria fundacional do significado através de uma analogia com o trabalho de campo de um antropólogo ao estudar as regras de etiqueta de uma tribo isolada. Quando um filósofo busca especificar a significação de uma expressão linguística, ele atua como um antropólogo tentando elaborar um manual de etiqueta para as várias situações possíveis ao lidar com os nativos dessa tribo. Mas, quando o filósofo investiga o que faz com que as expressões linguísticas sejam significativas, ele atua como esse mesmo antropólogo ao explicar de que modo as regras que ele descreve como sendo as regras de etiqueta possuem tal status. Assim, falamos até agora em fatos constitutivos do significado linguístico como falamos em fatos constitutivos das regras de etiqueta de uma tribo.

A analogia, entretanto, tem seus limites. Determinar que tipo de fato faz com que uma expressão seja significativa, e tenha o significado que ela tem, não é oferecer uma análise etimológica ou filológica dessa expressão. A dicionarização de uma palavra não a torna significativa, mas apenas registra o seu significado já pré-existente. Fatos constitutivos do significado são pressupostos pelo trabalho de lexicógrafos, gramáticos e filólogos.

A questão da fundação da significação linguística pode ser colocada agora de maneira mais clara quando a vislumbramos da perspectiva de uma teoria semântica. Consideremos alguns enunciados típicos do discurso semântico ou intencional, envolvendo os seus termos característicos:

(1) "Rouge" quer dizer vermelho em francês;

(2) "Solteiro" e "não casado" são sinônimos;

(3) Joana se referiu ao último filme que assistiu;

(4) A crença de Roberto era sobre coelhos;

(5) "Vênus e Saturno são planetas visíveis a olho nu" é um enunciado verdadeiro. 
Podemos querer saber da forma lógica desses enunciados, saber se expressões como "querer dizer", "significado", "verdadeiro" e afins devem aparecer no logiquês, ou, o que dá no mesmo, se eles tem espaço - como algum tipo de operador, no simbolismo de uma característica universal, ou se eles devem desaparecer depois da análise, tendo sido absorvidos em outros termos. E a resposta a essa indagação nos coloca no caminho de responder uma outra questão, pela qual alcançamos a questão fundacional: se os enunciados acima são tomados como sendo genuínos isto é, como possuindo valor de verdade, o que faz com eles sejam verdadeiros ou falsos? Que tipo de fato, quando ocorre, os torna verdadeiros?

Enunciados como (1) e (2) sugerem que convenções linguísticas tenham algum papel importante na explicação: uma palavra (tipo) tem o significado que ela tem por que uma comunidade de falantes de uma determinada língua convencionou pelo uso, de maneira tácita, que ela tem tal e tal significado. Mas isso é enganoso; que a significação linguística tem um aspecto convencional é inegável, mas isso pressupõe a ocorrência do tipo de fato que estamos procurando. Esse tipo de fato é aquele que, por assim dizer, nos permite "dar a vida" a ruídos ou inscrições e mantêlos "vivos" posteriormente como signos dotados de significação.

Notemos que as expressões que compõem o discurso semântico não são utilizadas apenas para falar sobre a significação especificamente linguística, uma vez que os atributos semânticos se aplicam tanto a pensamentos quanto a sentenças. Verdade e falsidade são frequentemente pensadas como tendo crenças como seu portador primário (cf. RUSSELL, 1910, cap. 12).

Há, desse modo, bastante espaço para discutir quais desses tipos de enunciado são conceitual ou logicamente mais básicos que os outros. Quais deles explicam os outros, se houver tipos mais fundamentais? E, ainda uma outra questão, relacionada à primeira: o que tem prioridade lógica e conceitual: a capacidade dos sujeitos de estarem em estados intencionais ou a capacidade deles de utilizarem linguagem?

De todo modo, a questão fundacional da significação foi relativamente negligenciada pelos filósofos da linguagem, que se ocuparam muito mais em desenvolver teorias semânticas, até que o texto seminal de Kripke Wittgenstein on rules and private language surgisse na cena filosófica. ${ }^{41}$ Nessa obra, Kripke faz

${ }^{41}$ BURGUESS \& SHERMAN (2014, pp. 4-5) apontam Conventions (1969), de Lewis, e Naming
and Necessity (1972;1980) do próprio Kripke como obras predecessoras imediatas no tratamento de 
uma reconstrução historicamente descompromissada das reflexões do $2^{\circ}$ Wittgenstein sobre as questões fundacionais do significado (agrupadas sob o epíteto "seguir uma regra"). ${ }^{42}$ Kripke vislumbra nessas passagens a articulação de um poderoso argumento cético contra a própria pretensão de dar uma resposta positiva a questão fundacional. Não haveria, segundo o cético do Wittgenstein de Kripke (a partir de agora, WK), nenhum tipo de fato que possa ser identificado como sendo constitutivo do significado linguístico; desse modo, não haveria nenhum estado de coisas objetivo cuja ocorrência ou não ocorrência fosse capaz de conferir verdade a enunciados semânticos. E essa conclusão cética teria consequências paradoxais: se a conclusão cética é verdadeira, então ela seria sem sentido, uma vez que o argumento implica que nenhuma expressão linguística é realmente significativa, incluindo a própria conclusão cética. O WK, então, busca oferecer uma espécie de solução cética, cujo objetivo seria conciliar a conclusão cética - de que enunciados semânticos não possuem "fazedores de verdade" objetivos - com uma atitude hermenêutica frente ao discurso semântico. Ou seja, a solução cética explicaria como os enunciados semânticos continuariam sendo considerados como legítimos, e não espúrios - de algum modo significativos - apesar da procedência da conclusão cética.

Como pontuamos na seção anterior, um sujeito querer dizer alguma coisa por outra não é apenas um tipo de estado exclusivamente importante na constituição da significação linguística, mas de qualquer tipo de estado intencional representacional. E isso pode ser constatado se parafrasearmos a problematização cética com um estado intencional que não envolva a significação linguística, e que mesmo por hipótese, assuma que a linguagem não é fundamental para a capacidade de representar a realidade. Nesse sentido, Hattiangadi observa que:

De fato, representações mentais são igualmente suscetíveis desse tipo de ataque cético. (...) Se eu tenho uma representação mental com conteúdo quadrado, de acordo com o

questões fundacionais do significado. Paul Grice também havia se dedicado ao assunto em "Utterer's Meaning and Intention" (1969).

42 "Minha presente obra é dificilmente um comentário sobre a filosofia tardia de Wittgenstein, nem mesmo sobre as Investigações Filosóficas" (KRIPKE, 1982, Prefácio, vii)." Merece ênfase que eu não estou nesse fragmento de escrito tentando nem falar por mim mesmo, ou, exceto em apartes menores e ocasionais, dizer nada sobre minhas próprias visões a respeito de questões substantivas. O propósito primário desta obra é a apresentação de um problema e um argumento, não a sua avaliação crítica. Primeiramente eu posso ser lido como um advogado (attorney) apresentando um grande problema filosófico tal como ele me pareceu (how it struck me)" (ibidem, Prefácio, p. ix). Kripke deixa claro, portanto, que além de não ter a pretensão de ser fiel ao Wittgenstein histórico, as posições avançadas no texto não são nem sequer endossadas pelo próprio Kripke. 
realista semântico, minha representação mental se aplica corretamente a todos e somente aos quadrados. A lista de todas as possíveis corretas aplicações da representação mental "quadrado" é infinita, e não há dúvida de que restam algumas aplicações de "quadrado" para serem feitas. Desse modo, o argumento cético que Kripke levanta contra o significado linguístico pode ser aplicado, mutatis mutandis, ao conteúdo da representação mental. A razão para isso é que (...) o conteúdo de qualquer representação (linguística ou mental) pode ser dada por suas condições de correção, e para (...) que se tenha uma particular representação mental, deve-se saber, ao menos tacitamente, as condições sob as quais ela corretamente se aplica. (2007, pp. 14-15)

Assim, o chamado "problema de seguir uma regra" é entendido hoje em dia não apenas como um problema dizendo respeito à constituição da significação linguística, mas do conteúdo representacional ou intencional. Buscamos não apenas por fatos constitutivos do significado, mas fatos constitutivos de pensamento: o que faz com que nossa crença de que a Terra gira em torno do sol seja de que a Terra gira em torno do sol? E o que faz com que nossa crença seja sobre a Terra, o Sol, e a relação de uma coisa girar em torno de outra?

\section{2. $O$ desafio cético}

O WK desenvolve seu argumento a partir de um exemplo de aritmética básica. Consideremos, primeiramente, que há números (especialmente números muito grandes com muitos algarismos diferentes, por exemplo, 84857893475) em relação aos quais jamais efetuamos qualquer operação aritmética que os envolva. No entanto, para evitar números estrambólicos como esse e facilitar as coisas, WK nos pede para supor que jamais tenhamos efetuado qualquer operação de soma em que uma das parcelas fosse maior que 57, e, além disso, que nós devemos determinar agora quanto é $68+57$. Realizamos sem dificuldade a operação e dizemos com segurança que $68+57$ equivale a 125 .

A partir de então, WK faz entrar em cena um cético que questiona a correção de nossa resposta. O cético do WK não duvida que a soma de 65 e 57 tenha 125 como resultado; o que ele questiona é que nós tenhamos usado até agora as expressões "+" e "mais" como querendo dizer adição. Ele então nos pede para considerar a hipótese de que, até agora, tenhamos utilizado essas expressões típicas da adição não para denotar a função de adição, mas ao invés disso, uma outra função que se assemelhe à adição. O cético chama essa suposta outra função de quadição (simbolizada por “ $\bigoplus$ ”) e a define da seguinte maneira:

Para quaisquer números $\mathrm{x}$ e $\mathrm{y}$ : 
(i) $\quad$ Se $x$ e $y<57$, então $(x \oplus y)=(x+y)$

(ii) Se $x$ ou $y \geq 57$, então $(x \oplus y)=5$

Se era a quadição que queríamos dizer pelas expressões “+”, “mais”..., então deveríamos responder ' 5 ' e não ' 125 '.

Uma vez que nossos usos pretéritos de “+”, "mais" ... são tanto compatíveis com a função de adição quanto com a de quadição, é inútil apelar a eles como justificativa para a nossa alegação de que queríamos dizer adição e não quadição com essas expressões. Dizer que nosso uso atual está de acordo com os usos anteriores não resolve nada, precisamente porque devemos explicar ao cético o que é esse "estar de acordo com" os usos anteriores.

O desafio que o cético nos coloca, então é o demonstrar que era mesmo a adição que nós queríamos dizer com “+”, "mais” ... no passado, e não a quadição ou qualquer outra função do tipo. ${ }^{43}$ De acordo com Miller, o cético de WK impõe duas condições para que o desafio seja satisfeito. A primeira condição é a de que a resposta tem de nos oferecer uma descrição do tipo de fato que é constitutivo do significado de “+”, "mais" .... A segunda é que tem de ser possível ler a partir desse fato o que constitui o uso correto e incorreto das expressões em questão; deve-se dizer por que a resposta ao problema “68+57=?” é justificada (MILLER, 2007, p. 169). Além disso, embora o cético do WK seja agnóstico em relação a uma série de detalhes relativos à teoria fundacional, ele parece pressupor que a análise de enunciados envolvendo a expressão "querer dizer" (to mean), em que algum sujeito quer dizer algo, que é a chave para responder à questão fundacional do significado. O cético parece pressupor e atribuir ao seu interlocutor uma certa imagem a respeito da formação do significado linguístico: cada sujeito possuiria sua própria linguagem - seu próprio idioleto - e então linguagens públicas seriam formadas pela convergência de idioletos. Por exemplo, o português seria a língua constituída

\footnotetext{
${ }^{43}$ Algumas sutilezas do argumento cético têm de ser mencionadas. A primeira é que a escolha do domínio da aritmética para suscitar o problema não desempenha nenhum papel além da ilustração. Ao invés de utilizar funções aritméticas e suas expressões designadoras, o WK poderia ter utilizado uma propriedade física e seu respectivo predicado, como azul e "azul". Uma vez que a conclusão cética é alcançada para um exemplo específico envolvendo um domínio específico, ela logo se generaliza de modo irrestrito. Além disso, para fazer com que sua própria argumentação seja inteligível, o cético não questiona de maneira preliminar a significatividade dos nossos discursos no presente. Ele põe em xeque primeiro que nós queríamos dizer alguma coisa por "+", "mais" ... no passado. Só após ter concluído que nós nunca usamos "+", "mais" ... significativamente é que ele faz o movimento de generalização temporal para concluir que não há fatos constitutivos do significado.
} 
pela convergência de idioletos dos seus falantes, de modo que eles tendem a associar aos mesmos signos sonoros e escritos às mesmas coisas. Ao aprender linguagem pública, eu estaria efetivamente sendo levado pelos meus instrutores a fixar o significado (em seus múltiplos aspectos) das expressões (tipo) dessa linguagem da mesma forma que os meus instrutores o fizeram. Assim, a ideia é que uma explicação para o fenômeno da significação linguística depende essencialmente da análise de enunciados cuja forma lógica seria

$s$ quer dizer $m$ por $e$ em $t$

e é buscando as condições de verdade de tais enunciados que nós conseguiríamos analisar as condições de verdade de enunciados como (1) e (3).

Uma resposta ao desafio cético exigiria, portanto, uma espécie de "varredura" teórica no domínio de nossos estados, processos e atos mentais, em busca um estado de coisas cuja ocorrência constitua nosso querer dizer adição por “+”. Em relação a esse ponto, o cético de WK nos concede acesso epistêmico ilimitado a esse domínio, qualquer que seja a sua natureza. Isso significa que, em princípio, poderíamos caracterizar esse fato constitutivo do significado como sendo até mesmo um estado de natureza interior e publicamente inacessível. Tal atitude do cético é considerada pelo WK como relativamente conscienciosa, quando comparamos com a atitude de Quine (1960;2013, cap. 2), para quem fatos constitutivos do significado deveriam necessariamente estar conectados com algum tipo de evento ou processo cientificamente perscrutáveis. Mas isso se deve justamente a maior ambição do cético do WK, de solapar toda e qualquer teoria que alegue haver algum tipo de fato semântico. Pois, como o WK coloca, "qualquer coisa que seja 'olhar dentro (looking into) da minha mente', o cético afirma que mesmo se Deus fosse fazê-lo, Ele ainda não poderia determinar que eu quis dizer adição por 'mais"”. (KRIPKE, 1982, p.14)

\subsection{Realismo e objetividade do significado}

Agora, antes de prosseguirmos na apresentação da argumentação tal como ela é desenvolvida no texto de Kripke, é fundamental desde já termos clareza a respeito do escopo e dos limites desse argumento cético. Qual ou quais teses o cético do WK está desafiando? Qual ou quais as consequências de fracassarmos em oferecer uma 
resposta satisfatória a esse desafio? Nesse ponto, nos é útil a análise oferecida por Hattiangadi (2007, p. 12-13).

A autora caracteriza o cético do WK como desafiando a posição que ela denominou realismo semântico, e que ela define como consistindo em duas teses principais:

(i) o que um sujeito s quer dizer ou entende por uma expressão linguística $e$ é dado por suas condições de correção (se $e$ for um enunciado genuíno, então dizemos que essas condições de correção são condições de verdade $)^{44}$

(ii) atribuições de significado a proferimentos linguísticos (vamos supor aqui que eles tenham como forma lógica 's quer dizer m por $e$ em t', onde ' $m$ ' é o significado de $e$ e 't' é um intervalo temporal) são factuais, isto é, elas possuem valor de verdade, e tal valor é conferido em virtudes de fatos objetivos, isto é, fatos que ocorrem ou não independentemente dos nossos juízos.

Chamamos a tese (i) de tese da normatividade e (ii) de tese da objetividade. A tese (i) é praticamente uma verdade conceitual: a significação (em todos os seus múltiplos aspectos) é normativa, e diríamos, de qualquer um que negue que o significado seja normativo em algum sentido, que esse sujeito não entende nossa concepção do que é ser (linguisticamente) significativo. Igualmente seria razoável supor que a ideia de que (ii) seja uma verdade conceitual: a objetividade do significado é também a ideia de objetividade do significado é também em algum sentido objetiva. A ideia de objetividade do significado é um dos pontos centrais das reflexões do $2^{\circ}$ Wittgenstein (o Wittgenstein histórico) sobre "seguir uma regra" nas Investigações, e, consequentemente, um dos pontos explorados por WK para gerar o problema cético ("parecer seguir uma regra não é a mesma coisa que seguir uma regra").

Notemos, entretanto, que (ii) vai além de estabelecer a ideia de que o

\footnotetext{
${ }^{44}$ Em seu texto, Hattiangadi caracteriza o realismo semântico em três, e não duas teses - separando condições de correção de condições de verdade (cf 2007, pp. 12-13); não parece haver, entretanto, qualquer motivo para essa discriminação além da ênfase retórica. Condições de verdade de enunciados constituem um caso particular de condição de correção do uso de expressões linguísticas, dado que o critério de sucesso de uma asserção é exatamente a sua verdade.
} 
significado é objetivo, ao definir em que consiste essa objetividade: "fatos objetivos que ocorrem ou não independem dos nossos juizos": (ii) é efetivamente uma definição realista de objetividade, no sentido de se comprometer com a tese de que como o mundo é não depende de nossas descrições. Mas onde propriamente o realismo semântico de Hattiangadi - e em particular o tipo forte de objetividade que "torna" o seu realismo semântico uma espécie de realismo - se relaciona com as "marcas do realismo" estabelecidas por Wright, da qual falamos no capítulo anterior?

No âmbito específico do discurso semântico, uma das "marcas do realismo" identificadas por Wright é exatamente o que ele chama de objetividade do significado (OS). A ideia é que, uma vez que o significado de uma expressão $e$ é definido (para uma comunidade, no caso de uma língua, ou mesmo para um único sujeito, se idioletos forem concebíveis) em um momento t, a correção ou incorreção de todos os usos posteriores - reais ou possíveis - a t está determinada de antemão; a correção ou incorreção desses usos não é determinada pelo que o sujeito ou a comunidade esteja propensa a considerar como correto. Como Wright coloca, é como se os sujeitos usuários da linguagem estivessem vinculados por contrato a usar a expressão $e$ com o significado que foi atribuído a $e$ em t.

Levando em consideração que OV é o traço mais forte característico do realismo, OV implica OS, ainda que OS não necessariamente implique OV. Desse modo, se o argumento cético é um argumento contra OS, o deve ser necessariamente contra $\mathrm{OV}$ - ao menos no domínio do discurso semântico em $1^{\mathrm{a}}$ pessoa: se fatos semânticos me fornecem um padrão de correção, guiando e tornando justificados os usos que eu faço de uma certa expressão $e$, certamente eu tenho de ter um acesso epistêmico a eles.

Já a relação de OS com a (in)dependência do juízo é mais complicada. Hattigandi caracteriza o seu realismo semântico dizendo que ele é "independente dos nossos juízos". Mas, uma vez que é um estado intencional de um sujeito (ou de vários) - de querer dizer alguma coisa por uma expressão - que constitui um fato semântico, essa alegação precisa ser qualificada. Em realidade, há um juízo que corresponde ao (ou expressa o) meu estado intencional constitutivo do significado de uma expressão, e nesse sentido, fatos semânticos são "juízo-dependentes”. A independência do juízo associada a OS deve ser a independência de juízos posteriores ao estado intencional do sujeito de querer dizer uma certa coisa por uma 
certa expressão, sendo que esses juízos não estabelecem, mas descrevem um fato semântico. Utilizando as equações básicas de Wright para explicar a situação, teríamos que a variável do lado esquerdo do bicondicional

$$
\mathrm{p} \leftrightarrow\left(\mathrm{C}_{\mathrm{s}} \rightarrow \mathrm{R}_{\mathrm{s}}\right)
$$

marca lugar para uma sentença expressando um enunciado descrevendo, e não constituindo, um fato semântico relativo a um ou vários sujeitos.

\subsection{Internalismo psicológico e regresso ao infinito}

Talvez a resposta ao cético mais popular entre os filósofos até o início do século passado, e ainda entre os leigos, devesse ser dada na linha de um internalismo psicológico: fatos semânticos são constituídos por estados mentais interiores, envolvendo impressões visuais e sonoras, ou ainda algum tipo de impressão sui generis. Se constituindo de vivências interiores, os fatos semânticos seriam dessa maneira transparentes ao próprio sujeito, cognoscíveis por ele através da introspecção. Por que esse tipo de resposta deixa um flanco aberto para uma instância do problema das outras mentes (nós conhecemos por introspecção os fatos semânticos relativos a nós; mas e em relação aos outros?) e, principalmente, porque ele não se integra facilmente às doutrinas metafísicas e epistemológicas inclinadas ao naturalismo hegemônicas na atualidade, o internalismo psicológico não figura como primeira "linha de tratamento" para o ceticismo semântico. Mesmo assim, vale a pena testarmos uma defesa nesses moldes contra o problema cético - tanto porque o internalismo psicológico goza ainda de um apelo intuitivo quanto porque o fracasso dessa defesa (tanto a luz tanto dos argumentos do cético do WK quanto do próprio Wittgenstein histórico) nos fornece uma motivação adicional e independente para rejeitar essa posição.

Suponhamos que apelássemos para nossas memórias no intuito de justificar que nós realmente queremos dizer adição por “+”. Lembramos de como nós fomos ensinados a somar e reensaiamos em nossa imaginação um procedimento simples de contagem de pequenas quantidades de objetos cotidianos - por exemplo - bolas de gude. Eu pego uma certa quantidade de bolinhas de gude e, depois de contar em voz alta cada unidade ("Uma.. duas,,, três... quinze"”) eu as ponho dentro de uma tigela; depois, eu tomo uma outra quantidade de bolinhas, uma outra tigela e faço a mesma coisa; por fim, eu pego uma tigela maior e deposito nela, de uma vez, todas as bolinhas que estão nas outras duas tigelas, e então, faço mais uma vez uma 
contagem de bolinhas com todas as que estão na tigela maior. O número de bolinhas que eu contei ao contar as bolinhas da tigela maior é a soma do número de bolinhas que eu havia contado para as outras duas tigelas: profiro em voz alta e nessa ordem o número de bolinhas de uma tigela, "mais", o número de bolinhas da segunda tigela, "é igual a", e o número de bolinhas da tigela maior. A maneira como eu fui instruído a somar através de procedimentos de contagem, bem como a minha habilidade de eu fazer isso mentalmente, envolvendo impressões visuais e sonoras na minha imaginação, é o que constitui o meu querer adição por “+”: eu sigo a regra da adição. ${ }^{45}$ (cf. KRIPKE, 1982, pp. 15-16)

Uma tal resposta, entretanto, não satisfaz de modo algum o cético, pois ele poderia questionar a minha tentativa de definir soma em função de um procedimento de contagem ao questionar a minha própria compreensão de contagem: quem disse que por "contar" eu queria dizer contar e não quontar (onde quontar é idêntico a contar até quantidades menores que 57; se a minha quontagem passa de 57, eu devo quontar 5):

É claro que se no passado "contar" (counting) quis dizer quontar (quouting), e se eu sigo a regra para "mais" que foi triunfantemente mencionada pelo cético, eu devo admitir que "68 +57 " deve produzir a resposta "5". Aqui eu supus que anteriormente "contar" nunca foi aplicado a pilhas formadas pela união de subpilhas tais que uma ou outra tinha mais do que 57 elementos (...); se "mais" é explicado em termos de "contar", então uma interpretação não padrão para esta última produzirá uma interpretação não padrão para a primeira" (KRIPKE, 1982, pp. 15-16)

O ponto do WK aqui (que pretende ecoar o próprio Wittgenstein) é bastante emblemático: apelar a uma regra para interpretar outra regra, nesse caso, não traz nenhum ganho explicativo, porque o problema é justamente que toda regra é passível de mais de uma interpretação. Podemos tentar explicar o que queremos dizer com "contar", mas o cético igualmente pode lançar mão de uma questão semelhante atingindo os elementos envolvidos em nossa explicação do que é o procedimento de contar, e assim por diante. Pois “(...) cada interpretação, juntamente com o interpretado, paira no ar; ela não deve servir de apoio a este. As interpretações sozinhas não determinam a significação.” (Investigações Filosóficas, $\S 198)$

\footnotetext{
${ }^{45}$ Seria ainda mais fácil imaginar uma "regra" para outros tipos de vocabulário. Por exemplo, o que faz com que eu queira dizer vermelho por "vermelho" é que em algum momento da minha vida eu associei (fui induzido pelo proferimento de um instrutor) as impressões sonora e visual da palavra "vermelho" com uma superfície vermelha - vamos supor, uma amostra de cor. Então eu faço uma cópia mental daquela amostra (crio uma amostra interior de vermelho para eu usar) e, a partir de então, se eu quiser justificar a minha aplicação do predicado "vermelho" a um objeto, eu comparo a impressão do objeto em questão com a minha amostra interior e vejo se são ou não semelhantes.
} 
Um tipo um pouco mais engenhoso de internalismo psicológico aponta para um outro caminho. Não são, ao menos não necessariamente, procedimentos mentais interiores envolvendo impressões imaginadas e lembradas que constituem um fato semântico. Mas, em vez disso, um sujeito querer dizer alguma coisa por uma expressão se constitui quando esse sujeito experiencia ou vivencia essa expressão de um modo peculiar; e esse "experienciar ou vivenciar a expressão de um modo peculiar" é ele próprio um estado mental irredutível a qualquer outro, com um quale particular, como dor, coceira ou enjôo por exemplo. Teríamos uma tal experiência qualitativa, detectável por introspecção, quando pensamos ou usamos a expressão linguística em questão. Segundo o WK, uma tal posição teria sido inclusive efetivamente defendida por autores do empirismo clássico, como Hume (KRIPKE, 1982, pp. 41-43).

Mais uma vez, entretanto, o cético (efetivamente ecoando o $2^{\circ}$ Wittgenstein nesse ponto) vem a triunfar. Em primeiro lugar, se aceitarmos raciocinar dentro da perspectiva do internalismo psicológico, logo constatamos que não há efetivamente um quale específico que acompanhe todos os meus usos de uma expressão - no caso, algo como uma dor um cócega que eu experiencio todas e apenas as vezes que eu efetuo corretamente uma soma. Se um dia experienciamos algo semelhante a isso, foi em uma situação excepcional (algo como um sentimento de espanto logo quando aprendemos a somar, ou ao vislumbrar a solução de um problema de aritmética que julgávamos difícil), de forma frequentemente efetuamos operações de adição (bem como utilizados qualquer outra expressão linguística) sem que nenhuma vivência interior peculiar chame nossa atenção (KRIPKE, 1982, p. 43).

No entanto, ainda que houvesse um estado qualitativo específico que acompanhasse todos e somente os meus usos de "+", "mais"... não estaríamos em melhor situação que antes, pois esse estado de nada serve para justificar a correção desses usos. Como assinala o WK:

Poderia exatamente isto ser o conteúdo de uma experiência de "querer dizer adição" (meaning addition)? O quão diferente teria sido se eu tivesse querido dizer quais? Suponha que eu efetuo uma adição particular agora, vamos supor, "5 + 7". Há alguma qualidade especial nessa experiência? Teria sido diferente se eu tivesse sido treinado para, e efetuado a correspondente quadição? Quão diferente seria a experiência se eu tivesse efetuado a corresponde multiplicação ("5 x 7") ou se eu tivesse respondido automaticamente com uma resposta diferente? (KRIPKE, 1982, p. 45).

Ou seja, o que estamos fazendo ao identificar um certo estado qualitativo como sendo o meu querer dizer adição por “+” é efetivamente interpretando este estado como constituindo esses fatos; mas ele poderia ser interpretado de outra maneira - 
como por exemplo, o quale da quadição, uma vez que eu, por hipótese, jamais somei números maiores que 57. De todo o mais, o que se estabelece é que a ocorrência de estados interiores envolvendo procedimentos na imaginação ou qualia relacionados ao uso de uma expressão não são nem uma condição necessária nem uma condição suficiente para que o significado se constitua. Um argumento envolvendo regresso ao infinito de interpretações sempre estará disponível antecipadamente ao cético para impugnar qualquer resposta na linha do internalismo psicológico.

\subsection{Disposicionalismo, normatividade e o "problema do erro"}

A (tentativa de) resposta ao desafio com a qual o WK mais se ocupa é aquela proposta pelo chamado disposicionalismo. A ideia básica do disposicionalismo é que o meu querer dizer mais por "mais" não consiste tão somente em meu comportamento atual - pretérito e presente, mas também por minhas disposições comportamentais. O fato de que eu quero dizer mais por "mais" se constitui no fato de que eu estou disposto a dar o resultado da soma quando instado a efetuar operações de adição. É verdade que meus usos pretéritos de “+”, “mais”... são compatíveis tanto com a adição quanto com a quadição; mas, se me tivessem perguntado “Quanto é 68 mais 57?”, eu teria respondido ' 125 ' ao invés de '5'. Com efeito, enquanto eu estiver disposto a somar ao me deparar com questões dessa forma ("quanto é x $+\mathrm{y}+\ldots$..?), eu estarei utilizando “+”, "mais".. com o significado de adição (KRIPKE, 1982, p.27).

Não é difícil explicar por que o WK discute mais longamente a estratégia disposicionalista de resposta do que qualquer outra. Para início de conversa, o disposicionalismo constitui uma estratégia de defesa mais engenhosa do que as demais estratégias aventadas na parte I do texto de Kripke. Além disso, uma resposta disposicionalista ao desafio cético possui grande afinidade com o realismo fisicalista e cientificamente orientado que é assumido pela maior parte dos filósofos de tradição analítica na atualidade: poucos estariam propensos a aceitar que o significado se constitui em função de vivências interiores aos sujeitos envolvendo imagens mentais publicamente inescrutáveis.

Uma vez que a análise disposicional dos enunciados de atribuição de significado envolve contrafactuais, podemos imaginar, a quão atrativa ela seria para, por exemplo, um realista modal (cf n37). Se eu quero dizer adição por “+”, então, em todos os mundos possíveis mais similares ao mundo atual, eu sempre 
respondo questões da forma “quanto é $\mathrm{x}+\mathrm{y}$...?" com a soma correta dos números em questão. Em especial, há um mundo possível que em tudo se assemelha ao nosso, pelo fato de que me fizeram exatamente " $68+57=$ ?" no passado ao invés de no tempo presente, e em tal mundo eu respondo " 125 " ao invés de " 5 ".

A essa estratégia disposcional o cético reage afirmando que ela "erra o alvo": o fato de eu estar disposto a dar uma resposta ao invés de outra não fornece nenhuma justificação, nenhuma explicação de porque eu deveria dar essa resposta:

Um candidato para o que constitui o estado de meu querer dizer uma função ao invés de outra, por um dado signo de função, deveria ser tal que, qualquer coisa que eu de fato fizesse (estivesse disposto a fazer) haveria uma única coisa que eu deveria fazer. Não é a visão disposicional uma equação entre performance e competência? (...)

Assim, parece que a explicação disposicional concebe equivocadamente o problema cético - encontrar um fato pretérito que justifique minha presente resposta. Como um candidato para um "fato" que determine o que eu quero dizer, ele falha em satisfazer a condição básica de um tal candidato (...) que ele deveria me dizer o que fazer em cada novo caso. Em última análise, quase todas as objeções à explicação disposicional se resume a esta. (KRIPKE, 1982, p. 24)

Mas é justa essa postura do cético? Uma rejeição imediata do disposicionalismo sob o fundamento de que ele não dá conta do caráter normativo do significado ( $\mathrm{e}$ da intencionalidade) soa como que uma defesa dogmática da ideia de que aspectos normativos não podem ser reduzidos sem resíduo a aspectos não normativos. Mas que essa tese é correta é algo em disputa dentro da própria argumentação cética, e, se o disposicionalista consegue explicar como fatos normativos podem ser reduzidos a fatos puramente descritivos (como fatos sobre disposições), então é justo que consideremos o desafio cético como tendo sido devidamente respondido. O ponto a ser explorado é então, no sentido de como a abordagem disposicional pode fazer tal coisa.

O cético então passa a argumentar por que a abordagem disposicional efetivamente fracassa em tentar capturar, com estados de coisas puramente extensionais, a normatividade própria dos conteúdos intencionais. Um primeiro ponto é que, dada nossa constituição natural, estamos dispostos, para uma infinidade de situações, a não efetuar corretamente operações de soma. Há números tão grandes (pensemos em um número com centenas de trilhões de algarismos!) tais que, antes que eu pudesse concebê-los, já teria morrido de velhice (KRIPKE, 1982, p. 27). Não precisamos nem ir tão longe na imaginação, dado que é perfeitamente esperado que muitos de nós não sejamos capazes de responder a questões relativamente simples de aritmética em situações que acontecem corriqueiramente 
- por exemplo, falta de tempo pra raciocinar, distração, humor depressivo etc. ${ }^{46}$ Ainda que estejamos dispostos a cometer esses erros, é bastante intuitivo considerar que nós de fato queremos dizer adição por “+”, “mais”...; que nós efetivamente sabemos somar (KRIPKE, 1982, p. 28). Desse modo, seria equivocado tratar nossas disposições comportamentais como constituindo fatos semânticos.

Essas colocações feitas pelo cético não esgotam, entretanto, o repertório do disposicionalismo. Podemos refinar essa abordagem ao buscarmos circunscrever as situações nas quais as nossas disposições são de fato constitutivas da significação, deixando de fora essas situações problemáticas. Teríamos desse modo um disposicionalismo sofisticado: o que constitui um sujeito s querer dizer x por uma determinada expressão linguística $e$ são fatos relativos ao que s estaria disposto a fazer em transações envolvendo $e$ sob algum conjunto de condições ideais apropriadamente especificado, ou ao menos condições ceteris paribus (isso é precisamente o que a forma geral das equações básicas de Wright nos mostra!). Através de uma especificação de condições ideais ou adequadas, daríamos conta de capturar a normatividade do significado (e do conteúdo intencional) e a distinção entre competência e execução. Se eu respondo " 125 ” a questão “ $68+57=$ ?" estando em condições adequadas, então eu, de fato, tenho uma razão para dar essa resposta; eu sou obrigado a responder com o resultado da soma se eu me encontro nessas condições; minha competência é definida pela minha execução atual sob determinadas circunstâncias (MILLER, 2007, pp. 207-208).

Mas como especificar essas condições ideais ou adequadas? Uma exigência que essa descrição de tais condições deve satisfazer, segundo Miller, é que no conjunto de enunciados que compõem essas condições, não deve aparecer nenhuma expressão própria do discurso semântico, intencional ou normativo - uma vez que estamos precisamente tentando defini-los em termos puramente descritivos e extensionais - sob pena de circularidade (isto é, considerando o lado direito de uma equação básica wrightiana $-\mathrm{C}_{\mathrm{s}} \rightarrow \mathrm{R}_{\mathrm{s}}$ - nenhum enunciado de $\mathrm{C}_{\mathrm{s}}$ pode conter coisas como “querer dizer", “acreditar", “estar obrigado a", "pensar”, etc, porque, no final das contas, são esses termos que nós estamos tentando definir).

O problema todo para o disposicionalismo sofisticado é que essa exigência

\footnotetext{
${ }^{46}$ Esse problema não é, evidentemente, específico relativamente ao discurso matemático ou mesmo lógico-formal. Situações análogas a essas são facilmente concebíveis para vocabulários envolvendo objetos físicos cotidianos.
} 
é virtualmente impossível de ser satisfeita. Retornemos ao caso concreto trazido pelo WK. Suponhamos que eu realmente queira dizer adição por “+”, mas por outro lado, eu não utilize o numeral ' 1010 ” da maneira usual; por uma excentricidade, eu não quero dizer 1010 por '1010', mas, ao invés disso, digamos, 3677. Desse modo, se me deparo com a questão “ $1010+1=$ ?” eu irei responder '3678' ao invés de ' 1011 ' mesmo em condições epistêmicas ideais. Outra possibilidade: eu realmente quero dizer mais por “+”, só que, novamente por uma excentricidade, eu não tenho nenhuma disposição para ser sincero se me apresentarem questões aritméticas: eu resolvo o problema corretamente em minha mente, e de fato, acredito na resposta que eu encontro, mas eu nunca verbalizo a resposta correta. Em ambos os casos, a especificação das condições ideais, para poder efetivamente corresponder a condições ideais, deveria fazer referência a um estado intencional: no primeiro, a outros estados constitutivos do significado linguístico, e no segundo, a minha disposição de propositadamente não exteriorizar verbalmente certas crenças.

O ponto é que disposições para responder verbalmente a determinados estímulos sonoros e visuais (como a colocação de problema aritmético) não se constituem de maneira isolada, mas possuem um caráter holístico envolvendo gamas de estados intencionais: de crenças, de desejos e inclusive de outros estados constitutivos do significado linguístico; especificar a gama de condições padrão para que minhas disposições sejam constitutivas do significado envolve excluir previamente estados intencionais de fundo ${ }^{47}$ inadequados.

Uma última possibilidade para a abordagem disposicional seria, segundo Miller, analisar essas sentenças contendo noções intencionais, que compõem as condições ideias ou adequadas, em sentenças Ramsey (ou sentenças Carnap). Basicamente, esse expediente permite uma "tradução" sistemática de um vocabulário em outro tido como conceitualmente ou ontologicamente mais básico (paradigmaticamente, sentenças Ramsey são utilizadas para explicar termos teóricos em função de termos observacionais). Não entraremos em minúcias formais aqui, mas o importante é que esse expediente em tese nos permitiria

\footnotetext{
${ }^{47}$ Boghossian (in LOEWER \& REY, 1991, pp. 90-91) fala “crenças de fundo" (background beliefs), mas seria apropriado falar em estados intencionais de fundo, uma vez que há outros tipos estados intencionais de fundo que podem exigir menção ao especificarmos as disposições de sujeito que constituem seu querer dizer alguma coisa por alguma expressão. Para sermos justos, talvez Boghossian tivesse esse ponto em mente, mas estivesse pressupondo que os demais tipos de estados intencionais podem ser explicativamente reduzidos às crenças.
} 
fornecer uma análise de vocabulário intencional e normativo em termos extensionais e puramente descritivos ainda que os estados intencionais de um sujeito devessem ser, como vimos, definidos "no atacado" holisticamente (cf. MILLER, 2007, pp.215-217).

Ainda assim, um problema fatal permanece: na estipulação das condições ideias, seria preciso fazer menção a uma quantidade potencialmente infinita de conjuntos de estados intencionais de fundo - conjuntos esses que deveriam estar ausentes para que a as condições ideais estivessem bem estabelecidas (MILLER, 2007, p. 215; HATTIANGADI, 2007, pp. 26-28). Uma sentença Ramsey especificando em termos puramente descritivos e extensionais todos os conjuntos de estados intencionais de fundo a serem eliminados seria uma sentença infinita, o que apenas implica que não seria uma sentença, e que suas condições de verdade jamais poderiam ser estabelecidas. Estaria depois disso tudo decretada a vitória do cético?

\subsection{Primitivismo}

Considerando o fracasso do internalismo psicológico - sempre vulnerável ao argumento do regresso ao infinito de interpretações - e da abordagem disposicional - na melhor das hipóteses incapaz de estipular as condições ideais que definiriam a constituição de um estado intencional - restaria ainda uma última estratégia a ser empregada contra o cético: sustentar que o meu querer dizer adição por "+" tem um caráter primitivo e sui generis, irredutível a qualquer outro estado mental envolvendo conteúdos fenomenológicos interiores ou disposições; "um estado de um tipo único por si mesmo" (KRIPKE, 1982, pp. 51-52).

De acordo com o WK, ao assumirmos uma tal posição, de fato não sobraria mais espaço para o cético problematizar tal como ele o fez anteriormente. Mas o preço a ser pago seria tornar a compreensão linguística, e a intencionalidade em geral, algo inteiramente "misterioso":

Um tal movimento pode em um sentido ser irrefutável (...). Mas parece também desesperado: ele deixa a natureza deste estado primitivo postulado - o estado primitivo de "querer dizer adição por "mais"” - completamente misterioso. (...) Pois como cada um de nós pode estar confiante de que de fato, no presente, queremos dizer adição por "mais"? (KRIPKE, 1982, p. 51)

Ainda, ecoando uma passagem das Investigações Filosóficas, o WK comenta:

Um tal estado teria de ser um objeto finito, contido em nossas mentes finitas. Ele não consiste em meu explicitamente pensar em cada caso em uma tabela da adição, nem mesmo meu codificar cada caso separado em meu cérebro: nós carecemos de capacidade 
para tal. Ainda (...) "de um jeito estranho" cada caso está "de algum modo presente". (ibidem, p. 52)

O ponto do WK é que o primitivista não consegue fornecer nenhuma explicação de como um tal estado sui generis conseguiria determinar de antemão que usos o sujeito deve fazer de uma expressão linguística. Como o meu querer dizer adição por "mais" no passado pode determinar a resposta que eu deveria dar a questão "68 $+57=? ":$

Presumivelmente a relação agora em questão fundamenta alguma implicação mais ou menos como essa: "Se eu agora quero dizer adição por 'mais'; então, se eu lembrar esse querer dizer no futuro e quiser estar de acordo com o que eu quis dizer, e não errar no cálculo, então, quando perguntado quanto é ' $68+57$ ', eu responderei ' 125 '. (...) Entretanto, permanece misterioso como a existência de qualquer estado passado finito de minha mente poderia implicar que, se eu quisesse estar de acordo com ele, e lembrasse do estado, e não cometesse erro, eu deveria dar uma determinada resposta a um problema de adição arbitrariamente longo (KRIPKE, 1982, p. 53)

O WK também deixar no ar uma certa acusação de circularidade (“(..) tal movimento pode em um sentido ser irrefutável"). O cético demandava um fato constitutivo do significado, e o que o primitivista entrega é exatamente a pressuposição de que tal fato existe e nada mais. Agora, como aponta Wright, é o cético do WK que pode ser acusado de ser circular. O desafio cético é encontrar algum fato ulterior que constitua o meu querer dizer adição por "mais". Podemos concordar com o cético de que não há tal fato, mas simplesmente porque o meu querer adição por "mais" consiste em um estado intencional sui generis primitivo, que não pode ser reduzido a qualquer outro estado. Além disso, quanto à acusação de que essa posição nos deixa com um "mistério", Wright responde que o mistério é "resolvido" quando nós refletimos que essa é simplesmente uma característica de nossa noção intuitiva e padrão de intenção (WRIGHT, 2001, p. 111).

É importante destacar que o que estamos chamando - seguindo Hattiangadi - de primitivismo engloba uma gama de posições que podem ser muito distintas entre si. Colin McGinn (1984), McDowell (1998, parte III) Baker \& Hacker (1984) (e quem sabe, o próprio Wittgenstein histórico) podem ser considerados primitivistas. Wright pensa estar defendendo também uma versão de primitivismo como resposta ao cético, embora no final das contas ele esteja muito mais próximo deste último, e da solução cética de WK, do que ele gostaria de estar. ${ }^{48}$ Realistas proposicionais também podem ser considerados como adotando uma posição

\footnotetext{
${ }^{48}$ Wright ele próprio rejeita IJ para esse domínio de discurso. Está assim, defendendo uma forma enfraquecida de antirrealismo semântico (cf. WRIGHT, 2001, cap. 5).
} 
primitivista - uma versão dessa posição que seja especialmente densa do ponto de vista ontológico (ao admitir entidades abstratas, fora do espaço-tempo e causalmente inertes, mas ainda assim acessíveis a nós). ${ }^{49}$

O nosso veredito, seguindo Hattiangadi, é então que os argumentos (e as suas derivações aprimoradas) apresentados na parte I de Wittgenstein on Rules and Private Language são insuficientes para impugnar a priori todas as teorias realistas do significado. $\mathrm{O}$ cético do WK estaria na verdade circunscrito às teorias reducionistas: as posições associadas ao internalismo psicológico seriam combatidas através de argumentos envolvendo o regresso ao infinito de interpretações; já as abordagens disposicionais seriam combatidas pelo argumento da impossibilidade de explicar o erro. Mas ele pouco tem a dizer contra teorias não reducionistas acerca da constituição do significado e da intencionalidade.

Ainda assim, há certa razoabilidade na desconfiança do WK em relação ao primitivismo. O primitivista pode alegar, como faz Wright, que ele faz jus a nossa noção intuitiva de intenção e estados intencionais: o conteúdo representacional pode ser "puro" - no sentido de não ser necessariamente acompanhado de uma fenomenologia própria nem de disposições identificáveis. Mas o primitivista ainda nos deve uma explicação, por assim dizer, positiva desses estados. Como eles vem a existir? Como eles se conectam com o mundo físico, espaço-temporal, ou mesmo com um mundo “interior”? E como se dá a determinação normativa que deles advém? $\mathrm{O}$ fato de que há muitos primitivismos, muitas vezes totalmente diferentes entre si, parece apontar por si só para a necessidade de desenvolver uma explicação (ou, como fazem os deflacionistas por influência de Wittgenstein, dizer por que nenhuma explicação é necessária).

\subsection{O argumento cético reconstruído: falácia naturalista, problema da "estranheza" (queerness) e o paradoxo cético}

\footnotetext{
${ }^{49}$ A tese de que estados intencionais são sui generis primitivos não exclui a possibilidade de seus defensores conceberem estados interiores envolvendo impressões de imagens, memórias ou algum quale particular como sendo característicos desse estado - como estados mentais que acompanham com frequência os estados sui generis primitivos. Frege sustentou que a apreensão do significado (sentido/conteúdo), que é algo objetivo, envolve também uma ideia subjetiva (cf. FREGE, 2009, p.135), ponto que é inclusive aludido no texto de Kripke (1982, p. 54). O próprio $2^{\circ}$ Wittgenstein, o maior algoz do internalismo psicológico, não nega em nenhum momento que possa haver tais imagens interiores (cf. Investigações Filosóficas, §6)
} 
A argumentação cética do WK, embora muito pungente, possui um caráter um tanto casuístico. O cético não oferece um argumento geral contra o realismo semântico / objetividade do significado, mas argumenta de uma maneira a posteriori em relação a cada versão de realismo apresentada. Agora, no capítulo 3 de Oughts and Thoughts, Hattiangadi oferece uma reconstrução da argumentação cética de modo a conferi-la exatamente esse caráter geral e apriorístico. Esse ponto, de perscrutar o caráter geral e apriorístico da argumentação cética é importante exatamente porque ele permite explicitar os seus fundamentos, os seus pressupostos - o que faz com que ele seja ao mesmo tempo tão relevante e difícil.

O grande insight da filósofa indiana nesse ponto é interpretar a argumentação de WK contra o realismo semântico como sendo semelhante à argumentação clássica contra o realismo moral - entendido aqui como a tese de que há fatos morais objetivos:

Se se diz dos supostos fatos morais, que eles são "fatos naturais", o realista comete uma “falácia naturalista". Se se diz dos supostos fatos morais, que eles são não-naturais, fatos morais vem a ser diferente dos fatos empíricos ordinários e consequentemente incognoscíveis. Similarmente, se nós concedermos que o significado é normativo, o cético de Kripke poderia ser considerado como mostrando que o realismo semântico enfrenta o mesmo dilema que o realista moral: se ele diz que fatos semânticos são naturais, como faz o disposicionalista, ele comete uma falácia, e se ele diz que fatos semânticos são não naturais, ele os torna inerentemente misteriosos e incognoscíveis. (HATTIANGADI, 2007, p. 39)

Mas, para que tenhamos esse dilema relativamente ao realismo semântico, Hattiangadi identifica duas teses que devem ser consideradas como pressupostas: o normativismo sobre o significado (N) e o internalismo motivacional (IM). O ponto de partida do normativismo é o truísmo - associado ao próprio conceito de significação linguística - que toda expressão significativa possui condições de correção (CC). Podemos assumir essa tese tendo como forma geral:

$(s$ quer dizer $m$ por $e$ em $t) \rightarrow(($ é correto para s usar $e$ em $\mathrm{t}) \leftrightarrow(\mathrm{CC}$ em $\mathrm{t}))$

onde "CC" é, assim como "m", uma variável mais geral que pode ser substituída por uma variável mais específica para o status lógico específico da expressão " $e$ " em questão (por exemplo, se "e" é um predicado, então teríamos algo como "(s quer dizer F por 'F' em t) $\rightarrow(($ é correto para s aplicar 'F' a um objeto x em t) $\leftrightarrow F x)$ ”). Agora, desse truísmo (considerando-o isoladamente ou em conjunto com outras teses) o normativista infere o que Hattiangadi (2007, p. 57) e Gluer \& Wikforss (2015, p. 64) denominam de tese da normatividade $(\mathrm{N})$ 
$(s$ quer dizer $m$ por $e$ em $t) \rightarrow((s$ deve usar $e$ em $\mathrm{t}) \leftrightarrow \mathrm{CC}))$

ou seja, a tese de que há normas que regem o uso de uma expressão significativa, e que essas normas têm uma natureza prescritiva: elas estabeleceriam deveres ou obrigações semânticas para os sujeitos, e isso significaria que elas de algum modo deveriam guiar a conduta de s envolvendo o uso de $e .{ }^{50}$

Já o internalismo motivacional (IM) seria um outro truísmo inerente ao discurso moral, e que poderia ser formulado como

( $s$ julga em $t$ que $s$ deve fazer com que $p$ seja o caso $) \rightarrow(s$ tem um motivo em $t$ a fazer com que $p$ seja o caso)

Suponhamos, por exemplo, que Maria seja uma das convidadas de um jantar chique, mas que a comida servida a ela na ocasião não estivesse do seu agrado. Suponhamos, além disso, que ela tenha como princípio moral uma extrema honestidade, de modo que ela julgue dever sempre dizer a verdade quando perguntada sobre alguma coisa. Se o anfitrião lhe pergunta se ela aprovou o prato servido, o fato de ela possuir um tal princípio moral, e julgar que deve sempre dizer a verdade, lhe fornece uma motivação para responder negativamente.

Essa ideia pode ser transposta para a esfera da significação linguística (e do conteúdo intencional) sem grandes dificuldades. Se eu julgo que devo usar "mais" como adição (como eu usei no passado), então eu estou por esse fato motivado a responder ' 125 ' se me perguntam “ $68+57=$ ?” (ou, dada uma eventual indisposição minha de responder expressamente a questão, eu estou ao menos motivado a julgar que 125 é a resposta correta).

Tendo tudo isso vista, Hattiangadi concebe que todo o ponto do cético do

\footnotetext{
${ }^{50}$ Essa é uma formulação tosca e simplificada da tese da normatividade. Um problema óbvio com ela é que parece simplesmente absurdo supor que nós tenhamos obrigações semânticas do modo ela afirma que nós teríamos. Se eu quero dizer verde por "verde", eu não tenho a obrigação de reportar a existência de um objeto verde todas as vezes que houver um objeto verde nas minhas adjacências; nem a obrigação de julgar in foro interno que algo é verde. No entanto, há várias maneiras de refinar essa formulação de modo a dá-la mais plausibilidade. Por exemplo, podemos trocar o operador "dever" por "poder" (cf. WHITING, 2009, p. 538). Alternativamente, podemos acrescentar uma condição de expressão junto às condições de correção: eu devo utilizar o predicado "(é) verde” se eu quiser expressar a minha crença de que algo é verde.
} 
WK é mostrar que o realismo semântico, o internalismo motivacional e o normativismo formam uma tríade inconsistente, e que, uma vez que IM e N seriam conceitualmente verdadeiros - apenas pela análise dos termos - é o realismo semântico que deveria ser abandonado. Quando as três teses são postas juntas, elas ou nos levam a uma falácia naturalista ou a nos comprometer com uma metafísica e epistemologia inaceitavelmente extravagantes.

\subsubsection{Falácia naturalista}

A tese da normatividade, ao menos prima facie, não implica que fatos normativos não possam ser analisados em termos de fatos não normativos supostamente mais básicos. Esses fatos não normativos supostamente mais básicos são normalmente - embora não necessariamente - tomados como sendo fatos empíricos ordinários, ou fatos naturais. São os fatos que constituem o objeto de estudo das ciências naturais - paradigmaticamente da física, química e biologia - e ainda, ao menos alguns fatos psicológicos e das ciências sociais, que podem ser retratados através de um vocabulário inteiramente descritivo e não intencional (HATTIANGADI, 2007, p. 40).

Nessa perspectiva, o que chamamos aqui de internalismo psicológico e a abordagem disposicional são ambas posições reducionistas; são posições pressupondo que fatos instituidores de normas e fatos semânticos (e intencionais) possam ser reduzidos em termos de uma fenomenologia interior ou de fatos possíveis (sendo que os fatos possíveis invocados na análise disposicionalista devem ser eles próprios reduzidos a coisas mais simples, como fatos reais atuais em outros mundos possíveis ${ }^{51}$ ). Ambas as posições caem para o cético: o internalismo psicológico é solapado pelos argumentos envolvendo o regresso de interpretações, e o disposicionalismo não consegue especificar as condições constitutivas dos estados intencionais. Em ambos os casos, o que temos é um problema de subdeterminação da intencionalidade (e mesmo da intensionalidade) pela extensionalidade.

Hattiangadi concebe o argumento cético do WK como uma versão do argumento contra a falácia naturalista, bastante discutido no âmbito da ética. De acordo com a tradição da filosofia moral, uma lição que pode ser extraída da obra

\footnotetext{
${ }^{51}$ Mesmo os fatos possíveis do realista modal deveriam ser considerados como fatos naturais, uma vez que eles seriam ontologicamente semelhantes aos fatos naturais do mundo atual.
} 
de Hume é que um dever ser jamais pode ser inteiramente reduzido a um ser; um enunciado normativo jamais pode ser inteiramente analisado em termos de um enunciado inteiramente descritivo. Tal tese é mais desenvolvida posteriormente por

\author{
G.E. Moore em seu Principia Ethica com o que ficou conhecido como "Questão
}

\title{
Aberta":
}

Moore argumentou que não há conceito ou conjunto de conceitos naturais analiticamente equivalente aos conceitos bom no mesmo modo que homem não casado é analiticamente equivalente a solteiro. Por exemplo, suponha que nós estejamos considerando se bom é analiticamente equivalente a tal que produziria prazer. Agora imagine alguém que apreenda o conceito bom e o conceito tal que produziria prazer. Moore diz que uma tal pessoa poderia, sem exibir qualquer confusão conceitual, dizer: "comer chocolate é prazeroso, mas isso é bom?" Em contraste, alguém que diga "comer chocolate é bom, mas isso é bom?" ou "comer chocolate é prazeroso, mas isso é aprazível?" de fato exibiria confusão conceitual. Se o conceito de ser tal que produz prazer fosse analiticamente equivalente ao conceito de ser bom então a questão de se o prazer é bom estaria fechada, exatamente como a questão de se o prazer é aprazível é fechada. Moore sugere que o Argumento da Questão Aberta é um artifício que pode ser usado contra qualquer suposto conceito natural, $N$-de modo que, para qualquer propriedade natural $N$, a plena apreensão tanto de $N$ e do conceito de bom não nos preclui de considerar seriamente se a propriedade referida por $N$ é realmente boa. (HATTIANGADI, 2007, p. 44)

Parafraseando a estratégia de Moore, o cético poderia colocar ao dispocionalista e

ao internalista psicológico: "Você está disposto/é levado por processos interiores a responder ' 125 ' quando perguntado quanto é $68+57$. Mas você quer dizer adição por '十' ao responder ' 125 ?" 52 .

Agora, Hattiangadi nota que a plausibilidade de um tal argumento depende que se assuma também o internalismo motivacional:

Assumindo o internalismo motivacional, o que faz de bom um conceito avaliativo é que juízos do que é bom são normativos; eles têm um vínculo conceitual com a motivação se alguém julga algo como sendo bom, então ipso facto esse alguém está motivado a buscá-lo. Em contraste, se alguém julga algo como sendo prazeroso, tal pessoa não está ipso facto motivado a perseguir tal coisa. Assim alguém poderia razoavelmente perguntar se o prazer é bom (i. e., vale a pena ser buscado), enquanto ninguém poderia razoavelmente colocar uma tal questão a respeito da bondade. E o que ocorre com o prazer ocorrerá com qualquer outro conceito natural, uma vez que conceitos naturais (...) carecem deste vínculo conceitual com a motivação. Disso se segue que nenhum conceito

\footnotetext{
${ }^{52}$ Notemos, entretanto, que o paralelo entre a Questão Aberta de Moore e a Questão Aberta do cético semântico não é perfeito, mas isso porque esta última é ainda mais pungente que a primeira. Com efeito, o cético do WK não exige, por exemplo, que a identidade entre os enunciados "s está disposto a responder ' 125 ' quando perguntado..." e "s quer dizer adição por '+"” seja uma identidade analítica. consideraríamos que o cético deveria se dar por satisfeito se conseguíssemos uma identidade intensional. Nesse sentido, Glüer\&Wikforss (in ZALTA, 2020) fazem uma diferenciação entre um argumento "forte" e um argumento "fraco" contra a naturalização da intencionalidade. Um argumento forte foi apresentado no final de 3.3 ao tratar do disposicionalismo sofísticado, ao sustentar que as condições padrão ou ideais que constituiriam um fato semântico seria, a priori, impossíveis de serem estabelecidas. Um argumento fraco contra a naturalização não precisa excluir essa possibilidade, mas deve apenas terminar por concluir (por outros meios) que "algo se perde" ao se analisar enunciados normativos em termos de enunciados descritivos. O Argumento da Questão Aberta original de Moore pode ser lido como um argumento "fraco". Já o cético do WK pode ser tomado como oferecendo um argumento forte.
} 
avaliativo pode jamais ser (...) equivalente a quaisquer conceitos naturais. (Hattiangadi, 2007, p. 46)

Retomando o paralelo agora tendo IM em vista, o cético reformularia sua indagação a nós: "Você está disposto a/ é levado por processos interiores a responder ' 125 ' quando perguntado quanto é $68+57$. Mas você tem um motivo para responder '125'?’'

\subsubsection{A estranheza (queerness)}

O problema da "estranheza" diz respeito ao outro "chifre" do dilema: o chifre antirreducionista, que aloja as chamadas estratégias "primitivistas" de resposta ao cético. O paralelo que Hattiangadi faz nesse ponto é entre a acusação do cético de WK (muito pouco fundamentada, a bem da verdade) à tese de que estados intencionais são estados primitivos sui generis e o argumento que J.L. Mackie faz contra um tipo não-naturalista de realismo moral em Inventing right and wrong.

$\mathrm{O}$ argumento principia alegando que, se nós formos ao mesmo tempo realistas e não naturalistas em metaética (isto, se aceitamos que a falácia naturalista é efetivamente uma falácia), nós devemos sustentar que os princípios morais devem ser tanto objetivos quanto categoricamente prescritivos. $\mathrm{O}$ que Hattiangadi e os filósofos morais chamam de objetividade aqui é, na terminologia de Wright para as "marcas do realismo", a independência do juízo (IJ): "dizer que (princípios morais) são objetivos é dizer que princípios morais são verdadeiros independentemente de nossos juízos sobre se eles são verdadeiros (2007, p. 48). A prescritividade categórica, por outro lado, significa que fatos (princípios) morais nos dão razão para agir independentemente de nossos desejos e disposições (ibidem):

Se eu desejo ir a Edimburgo no menor tempo possível, o fato de que um avião me levará até lá me dá uma razão para pegar um voo até Edimburgo. (...) Se eu não quero mais ir a Edimburgo no menor tempo possível, então eu não tenho mais uma razão para pegar um voo até Edimburgo (...). Em contraste, princípios morais parecem categoricamente prescritivos no sentido de que eles subsistem (hold) independentemente de nossos desejos. O princípio de que eu devo ajudar os menos afortunados me dá uma razão para doar a Oxfam ainda que eu não tenha o desejo de doar a Oxfam. É fortuito se eu queria doar a Oxfam ao mesmo tempo em que eu tenho uma razão para fazê-lo, mas não é necessário que eu queira doar a Oxfam para que eu tenha uma razão para assim proceder.

A partir de então, novamente entra em cena o internalismo motivacional (IM). De acordo com IM, o juízo de s de que s deve tornar o caso que p oferece uma motivação para $\mathrm{s}$ agir de forma que $p$ venha a ser o caso ainda que $s$ não tenha $\mathrm{o}$ desejo de que p. Ou seja, nossos juízos morais normativos poderiam ter essa relação 
interna com a motivação apenas se os supostos fatos que os tornam verdadeiros (os fatos morais normativos) fossem categoricamente prescritivos - i. e., se eles dessem um motivo para s independentemente dos desejos de $s$.

Entretanto, de acordo com Hattiangadi, o ponto de Mackie é justamente que nós não temos familiaridade com nenhum estado de coisas que possua essa característica. Como bem salienta a autora:

(...) nenhum dos nossos fatos ou propriedades ordinárias, com os quais nós estamos familiarizados, parecem ser tais que a sua mera apreensão motive agentes racionais a agir. Este é claramente o caso com propriedades tais como vermelhidão ou ser quadrado - a mera apreensão daquelas propriedades não motiva os agentes racionais a agir de modo totalmente independente dos desejos que eles possuem. (HATTIANGADI, 2007, p. 49) Ou seja, quando supomos que há fatos normativos - que são ao mesmo tempo objetivos e categoricamente prescritivos - nós estaremos postulando fatos absolutamente diferentes de quaisquer outros fatos com os quais tenhamos familiaridade, até mesmo fatos matemáticos não naturais, se estes existirem (ibidem). Desse modo, o tipo de argumento apresentado contra os realistas proposicionais em 2.1.1.4 pode repetido e generalizado contra todos aqueles que sustentam que a normatividade (onde quer que ela exista, seja na moralidade, seja na intencionalidade) é irredutível a fatos puramente descritivos (ibidem, p. 50):

O antirreducionista está desse modo comprometido com uma epistemologia bizarra, de acordo com a qual eu devo ter alguma faculdade de intuição não sensorial de modo que eu possa me tornar familiarizado com fatos normativos. (...) porque propriedades não naturais são por definição não causais, o antirreducionista teria de explicar como poderia ser que a apreensão por agentes racionais de tais propriedades poderia ter o efeito de motivar seu agir. (...) Se propriedades normativas são não causais, é difícil ver como eles poderiam impingir sobre agentes racionais de modo que os motive a agir.

Agora, o ponto de Mackie é que, se propriedades normativas são não-naturais (e, portanto, não causais), é difícil ver como elas poderiam influenciar agentes racionais de modo a motivá-los a agir de uma forma ou de outra. $\mathrm{O}$ antirreducionista parece, então, inegavelmente comprometido com uma ontologia e uma epistemologia extravagantes.

\subsubsection{O paradoxo cético}

Os dois chifres do dilema terminam por nos levar à conclusão do cético do WK (CWK):

Para qualquer expressão $e$ de uma linguagem $\mathrm{L}$, e para qualquer sujeito s a qualquer tempo t, $e$ não é significativa. 
O próprio WK fala dessa conclusão como sendo paradoxal, parafraseando o parágrafo 201 das Investigações Filosóficas ("Nosso paradoxo era: uma regra não poderia determinar um modo de agir, pois cada modo de agir deveria estar em conformidade com ela."); ele a considera “insana e intolerável” (KRIPKE, 1982, p. 60), sem, porém, explicitar exatamente ela porque ela teria esse caráter. Por sua comparação subsequente do ceticismo semântico com o ceticismo de Hume a respeito da objetividade da necessidade causal, Kripke ainda dá a entender que CWK seria paradoxal no sentido de contrariar fortemente nossas intuições préteóricas. Nesse caso, CWK seria um paradoxo especificamente por ter como consequência direta a impugnação da "legitimidade" do discurso semântico (ou ao menos parte dele). No entanto, ao levarmos em conta a distinção entre linguagem e metalinguagem, a partir de CWK podemos formular efetivamente um paradoxo no sentido mais forte possível - de derivar da conclusão uma contradição - e não apenas consequências intuitivamente desagradáveis (a comparação mais correta seria com o Paradoxo do Barbeiro, de Russell).

Pois, uma vez é um truísmo que, para qualquer sentença verdadeira o predicado "é verdadeiro(a)" (ou qualquer outro predicado com função veritativa) é iterável com relação a essa sentença ${ }^{53}$, temos "CWK é verdadeira". No entanto, se CWK é verdadeira, então, disso se segue que "CWK não é verdadeira". Pois CWK é também uma expressão linguística (está por uma sentença, que é também uma expressão linguísitca) e, ipso facto, $\mathrm{CWK}$ alega que não há expressões significativas (portanto não há expressões com valores de verdade). Chamemos essa interpretação forte do paradoxo cético de antinomia cética.

Assim, e levando em consideração a reconstrução do argumento cético fornecida por Hattigandi - explicitando suas premissas implícitas - o que temos é no final das contas uma refutação da conjunção do realismo semântico (objetividade do significado/independência do juízo relativamente à semântica) com o internalismo motivacional e o normativismo, ou seja, uma demonstração de que essas três teses formam uma tríade inconsistente, uma vez que elas implicam uma contradição:

\footnotetext{
${ }^{53}$ Dummett (in EVANS \& MCDOWELL, 1976;2005; p. 77) chamou esse truísmo de princípio da equivalência: se p é verdadeiro, então "p é verdadeiro" também é verdadeiro.
} 

1 (realismo semântico \& N \& IM) $\rightarrow$ (antinomia cética) Premissa
$2 \sim($ antinomia cética $)$
Premissa

(3) (realismo semântico \& N e IM) ～1,2 Modus tollens

A solução que o WK propõe na $2^{\mathrm{a}}$ parte de Wittgenstein on Rules and Private Language consiste basicamente em descartar o realismo semântico, preservando uma concepção forte de normatividade $(\mathrm{N})$ e o internalismo motivacional. Imaginamos que evitar a antinomia ao mesmo tempo em que se abre mão da noção intuitiva de que o fenômeno da significação linguística é objetivo seja o que WK quer dizer com "evitar as consequências desastrosas do paradoxo". No entanto, bem podemos constatar que se trata de um trade off: se concebemos a ideia de que o significado linguístico é objetivo no sentido da independência do juízo de Wright é absolutamente imprescindível, então devemos escolher negar $\mathrm{N}$ ou IM.

\subsection{A solução cética}

Considerando as observações subsequentes do WK, a versão mais pungente do paradoxo cético - a antinomia cética - seria evitada ao constatarmos que nossa prática envolvendo o uso de vocabulário semântico não exige, para que ela seja considerada legítima, o tipo de coisa que o cético exige (a existência de fatos semânticos e o conhecimento desses fatos pelos sujeitos). ${ }^{54} \mathrm{O}$ WK sustenta que se nós conseguirmos identificar o papel e a utilidade do discurso semântico, então estaremos perfeitamente justificados em considerarmos seu uso como sendo legítimos (MILLER, 2007, p. 175)

É precisamente essa tarefa, de encontrar as condições de uso adequado das expressões semânticas, que o WK busca empreender na parte na parte II da referida preleção (KRIPKE, 1982, p. 92):

Nós podemos dizer, de alguém, que ele segue uma certa regra quando suas respostas concordam com as nossas próprias e negar tal coisa em caso contrário; mas qual é a

\footnotetext{
54 Conjugando as colocações do WK com a nossa análise própria da situação, diríamos que a proposta de solução do WK é "cética" porque ela aceita a versão mais "fraca" do paradoxo, de que não há fatos semânticos. Uma solução cética seria assim, redefinida em nossos próprios termos como uma solução que aceita uma conclusão paradoxal no sentido de ela ser "contraintuitiva", e que busca a partir daí mostrar sustentando que esse caráter contraintuitivo de certa posição não implica em uma antinomia, i. e, um tipo mais forte e literalmente paradoxal de tese.
} 
utilidade dessa prática? A utilidade é evidente e pode ser apresentada ao considerarmos novamente um homem que compra algo com um merceeiro (experimento mental da seção 1 das Investigações Filosóficas). O cliente, ao lidar com o merceeiro e pedir cinco maçãs vermelhas, espera que o merceeiro conte como ele próprio (o cliente) conta, e não de acordo com algum padrão de regra bizarro; e, assim, se suas interações com o merceeiro envolvem um cálculo, tal como " $68+57$ ", ele espera que as respostas do merceeiro concordem com suas próprias respostas. De fato, ele pode confiar na conta do merceeiro. Evidentemente o merceeiro pode ainda assim cometer erros; ele pode até mesmo ser desonesto em seus cálculos. Mas, na medida em que o cliente atribui a ele a apreensão do conceito de adição, ele espera pelo menos que o merceeiro não se comporte bizarramente, como se estivesse seguindo uma regra semelhante a do quais; e pode-se mesmo esperar que, em muitos casos, ele alcançará a mesma resposta que o próprio cliente teria dado. Quando nós afirmamos que uma criança dominou a regra da adição, o que nós queremos dizer é que nós podemos confiar que ela vai reagir do mesmo modo que nós em interações tais como a que acabou de ser mencionada, entre o merceeiro e o cliente. Nossa vida inteira depende de incontáveis interações como essa, e o "jogo" de atribuir a outros o domínio de certos conceitos ou regras dessa forma mostra que nós esperamos que eles se comportem como nós.

A utilidade do vocabulário semântico é, assim, clara: permitir a distinção, em geral, entre aqueles sujeitos que são membros de uma comunidade linguística (ou de uma parte dela - no caso em que o domínio discursivo em questão é um domínio especializado, como o da matemática) e aqueles que não são membros isto é, não são em geral considerados aptos a participar de determinadas transações sociais envolvendo linguagem.

Ao longo da parte II, o WK foca quase que exclusivamente na análise - a partir de sua proposta - da expressão "querer dizer" situada em contextos em que ela é atribuída a sujeitos. Mas essa análise na maioria das vezes pode ser estendida sem grandes dificuldades para as outras expressões características do chamado vocabulário semântico. Consideremos novamente os enunciados semânticos arrolados:

(1) "Rouge" quer dizer vermelho em francês';

(2) "Solteiro" e "não casado" são sinônimos;

(3) Joana se referiu ao último filme que assistiu;

(4) A crença de Roberto era sobre coelhos;

(5) "Vênus e Saturno são planetas visíveis a olho nu" é um enunciado verdadeiro.

Enunciados cuja forma gramatical seja semelhante a (1) e (2) envolvem as expressões "querer dizer" e "significar" atribuídas agora a linguagens específicas. Elas podem ser interpretadas como uma espécie de esclarecimento de um sujeito para outro - onde ambos fazem parte da mesma comunidade linguística (no caso, a dos falantes do português), a respeito do papel que uma determinada expressão a 
ser definida desempenha a partir de uma outra expressão, já conhecida. Em (1), isso é feito com uma expressão de outra língua (no caso, o francês) e as condições de proferimento de (1) implicitamente trazem um ar de recomendação: "Se você quiser dizer que algo é vermelho com alguém que pertence (apenas) à comunidade do francês, então você deve sempre proferir 'rouge' para produzir os efeitos que costumamos produzir ao proferir 'vermelho' em português".

Uma explicação para o enunciado (3), envolvendo uma expressão referencial, já é um tanto mais complicada. Se eu digo de alguém, que esse alguém se referiu a alguma coisa, minha atribuição tenha (talvez) o papel de expressar que eu espero desse sujeito que ele predique algo dessa coisa, ou que ele saiba identificar objetos de acordo com certas caracterizações do mesmo modo que eu e os demais falantes fazemos. Esse raciocínio é supostamente estendível para as expressões de crença e "ser sobre" contidas no enunciado (4). Se dizemos que a crença de alguém é sobre algum tipo de coisa, então esperamos que ela possa se manifestar no comportamento (ou nas disposições comportamentais) do sujeito associada a presença daquele tipo de coisa no ambiente percebido pelo sujeito.

Em relação às expressões veritativas, como as que ocorrem em (5), o WK salienta rapidamente que elas não atestam fatos e se compromete com a chamada teoria da redundância da verdade, baseando-se numa passagem da seção 136 das Investigações ("p" é verdadeiro = p) (KRIPKE, 1982, p. 86). De fato, o tipo de abordagem promovida pelo WK tem grande afinidade com uma concepção deflacionária de verdade. De acordo com tais concepções (a teoria da redundância é uma espécie dela) dizer de uma sentença que ela é verdadeira não teria nenhum valor cognitivo, mas apenas pragmático: o de indicar anuência em relação a um proferimento feito por outro sujeito (cf. STRAWSON, 1950, 164). Assim, se eu dissesse "' $68+57=125$ ' é verdadeiro", eu estaria não mais do que exprimindo a minha anuência para com essa sentença, ou a minha inclinação em responder ' 125 ' a questão “68 + 57=?”.

Agora, uma consequência de toda essa linha de análise proposta pelo WK é que o uso do vocabulário semântico não tem nenhuma função se considerarmos os sujeitos isoladamente. É somente no contraste entre o uso que um sujeito faz de certas expressões linguísticas e o uso que uma comunidade faz (esteja ou não o sujeito em questão inserido nessa comunidade) dessas mesmas expressões que a distinção entre ser correto e parecer ser correto ganha o seu propósito. Por isso, o 
WK identifica a sua solução cética como sendo o genuíno argumento da linguagem privada.

É importante ressaltar que a parte II de Wittgenstein on rules and private language contém uma série de imprecisões e ambiguidades. Afinal, enunciados semânticos possuem valor de verdade em função de alguma outra coisa que não sejam fatos semânticos objetivos? Eles possuiriam algum tipo de status cognitivo ou possuiriam apenas uma significação pragmática, servindo apenas para os sujeitos exprimirem suas atitudes avaliativas? Não há na literatura secundária consenso sobre essas questões.

A interpretação canônica, a primeira a surgir (cf. BOGHOSSIAN in MILLER \& WRIGHT, 2002, pp. 507-549; WRIGHT in MILLER \& WRIGHT, 2002, pp.246-254) é a de que WK estava atacando a própria ideia de que enunciados semânticos tivessem valor cognitivo, dado que não haveria fatos ou estados de coisas cuja ocorrência ou subsistência pudesse torna-los verdadeiros. Se eles tivessem alguma função na linguagem, então essa função seria a de expressar algum tipo de atitude do sujeito alvo da atribuição perante uma situação, e não de descrever ou representar essa situação. Pela interpretação canônica, o status lógico-semântico dos enunciados semânticos seria semelhante àquele atribuído a enunciados morais ou estéticos pelos emotivistas, por exemplo. Desse modo, o WK estaria defendendo uma posição irrealista ou não factualista para o discurso semântico (MILLER, 2007, p. 178).

Mas a partir da década de 1990 surge uma outra linha de interpretação. Autores como Wilson (cf. WILSON in MILLER \& WRIGHT, 2002, pp. 366-390) e Kusch (2006) tomaram o WK não como um irrealista ou não factualista, mas como usando o argumento cético para motivar um tipo não realista de factualismo, a ser considerado ao menos dentro do âmbito do discurso semântico. Segundo essa segunda linha de interpretação, a solução cética do WK consiste precisamente em recuperar a ideia de que há fatos ou estados de coisas cuja ocorrência torna enunciados semânticos verdadeiros, mas ao tempo concebendo esses fatos como não objetivos - isto é- como inteiramente constituídos pelas atitudes atuais dos sujeitos usuários da linguagem. A principal motivação para adotar a linha revisionista, segundo os seus proponentes, é a de que ela tornaria a solução cética mais atrativa, do ponto de vista filosófico substantivo; não por acaso, e, ao contrário dos intérpretes canônicos, a maioria dos defensores dessa segunda interpretação 
assumem uma posição bastante simpática ao que eles consideram como sendo o WK.

Apesar das diferenças entre as duas linhas de interpretação serem teoricamente significativas, ambas são expressões de uma posição mais geral chamada de construtivismo social - especificamente, uma versão de construtivismo social para a semântica e a intencionalidade.

Kusch (apud HATTIANGADI, 2007, p. 87) ilustra a diferença entre as explicações realista e social construtivista da representação intencional através de uma analogia com as concepções de criação divina moderna (deísta) e medieval. Pela concepção deísta, Deus simplesmente coloca o mundo "em movimento" e então se torna supérfluo. Pela concepção medieval - da criação contínua, Deus jamais é supérfluo; Ele continuamente não só se intromete em nosso mundo como é uma espécie de sustentáculo do próprio mundo, de modo que se Deus deixasse de existir, toda a realidade também o deixaria.

A semântica realista é semelhante à criação divina do deísmo: depois de $\mathrm{s}$ aprender o significado de uma palavra da sua comunidade linguística (ou simplesmente depois de s fixar o significado de uma palavra para si próprio), o que s quer dizer pela palavra determina de antemão se os usos de s estão corretos, e a comunidade se torna supérflua. Já o social construtivismo é semelhante à criação contínua: o acordo a partir dos falantes competentes determina, caso a caso, se os proferimentos de $s$ podem ser ou não chamados de corretos. E esse acordo nada mais seria, no final das contas, do que a mera convergência de comportamentos entre os sujeitos usuários de linguagem - isto é, o fato de que na maioria das vezes os sujeitos se comportam da mesma maneira em função dos mesmos tipos de estímulos ambientais e de transações sociais linguisticamente mediadas.

Um primeiro problema para o social construtivismo, como bem salienta Hattiangadi, é que as noções de significado e correção subjazem a noção de acordo (2007, p. 94):

“(...) nós atribuímos um significado aos proferimentos primeiro, antes que nós possamos dizer que eles concordam. Ao fazer isso, nós assumimos que aqueles proferimentos tem condições de uso correto (...)"

Se dois ou mais proferimentos podem ser ditos como estando "de acordo", disso depende precisamente o que eles querem dizer. O social construtivismo toma por garantido que a noção de acordo entre usos de expressões linguísticas já é bem entendida, quando na verdade o entendimento do que é esse acordo depende de já 
termos esclarecido o que é uma expressão proferida querer dizer o mesmo que outra.

Em defesa da solução cética, poder-se-ia dizer que também a noção de acordo deveria ser interpretada do mesmo modo que as noções semânticas, ou seja, como um estado conativo ao invés de cognitivo; um proferimento com a forma gramatical "s concorda comigo", nessa toada, teria o mesmo status pragmático que "Fantástico, $s$ !", o de mostrar aprovação ou anuência. Entretanto, isso não escapa ao próprio argumento cético, porque, ainda que juízos expressivos não tenham valor de verdade, seus termos devem ser significativos para que eles tenham essa função. E para que eles sejam significativos, deve haver fatos semânticos que estabeleçam seu significado. Como destaca a autoria indiana:

(...) se Smith deve expressar sua aprovação para com Jones (...), então o proferimento de Smith tem um conteúdo. Se Smith diz "Eu aprovo suas respostas" ou "Muito bem, Jones" estas apenas serão expressões da aprovação se Smith quer dizer eu aprovo por "eu aprovo" e "muito bem", ao invés de qualquer outra coisa ou nada. Sons sem significado não expressam nem aprovação nem desaprovação, assentimento ou discordância. As mesmas considerações surgem ainda se nós assumimos que Smith expressa sua aprovação ou desaprovação sem o uso de palavras: quando Smith desaprova, ele dá uma palmada (snack); quando ele aprova, ele dá um beijo em Jones. Mas, se Smith dá um beijo em Jones, por que ele deu um beijo em Jones? O que Smith aprova? Jones não tem como saber, assim como o cético também não tem. (2007, p. 97)

Este ponto contra o irrealismo semântico pode ser feito de outro modo. Lembremos que, no capítulo anterior, estabelecemos a prioridade da força assertórica sobre as demais forças exatamente pelo fato de podermos expressá-las por meio de asserções (como foi argumentado, preferencialmente por meio de enunciados de uma característica universal), mas não podemos expressar a força assertórica por meio de sentenças não assertóricas.

Dizer que enunciados semânticos não tem valor de verdade nada mais é do que dizer que a sua forma gramatical não é congruente com a sua forma lógica isto é, que as sentenças declarativas das linguagens naturais que contém vocabulário semântico não possuem força assertórica, e não são enunciados genuínos.

No caso do emotivismo, os pseudoenunciados morais e estéticos podem ser parafraseados em sentenças que são elas mesmas verdadeiras ou falsas. Se estivéssemos na pele de um emotivista, diríamos que a forma lógica de 'João é bom' não é predicativa $(\mathrm{Fa})$, mas relacional $(\mathrm{aRb})$, no sentido de que o sujeito que profere a frase aprova ou tem uma atitude avaliativa positiva em relação a João. Mas, quando aplicamos o mesmo raciocínio para o irrealismo/não factualismo, as coisas não funcionam. Dizer que "s quer dizer mais por ' + " " tem a forma lógica de " $s$ " confia em $s$ para participar de transações envolvendo “+"” não resolve nada, por 
que podemos repetir a questão cética a respeito das expressões relacionais "aprovar" e "confiar"; o irrealista/não factualista efetivamente corta o galho onde ele está sentado.

E quanto ao social construtivista do tipo factualista? Estaria então o antirrealista/factualista imune a essa objeção?

Suponhamos dois sujeitos, João e John, tal que ambos estejam na mesma margem de um rio e avistem simultaneamente um cisne, de modo que, em reação a tal avistamento, ambos realizem um proferimento linguístico. João diz "Olhe, um cisne!". O que deve acontecer para que o proferimento de John conte como estando de acordo ou convergindo com o de João?

A resposta mais promissora é que, dados dois proferimentos, eles devem contar como expressando o acordo entre dois ou mais sujeitos se (i) são utilizados sob as mesmas circunstâncias e/ou (ii) são tokens de um mesmo tipo. No caso de (i) há um acordo entre proferimentos se eles são produzidos nas mesmas circunstâncias se, por exemplo, eles ocorrem em decorrência das mesmas estimulações retinais e auditivas, ou na presença dos mesmos objetos físicos. No caso de (ii), dois proferimentos são tokens de um mesmo tipo quando eles são sintaticamente semelhantes; eles são congruentes, ou seja, eles exibem um mesmo padrão sonoro e escrito e são "gerados" segundo um mesmo procedimento. A condição (i), em princípio, seria por si só uma condição suficiente para o acordo, uma vez que os proferimentos podem ser tokens de tipos diferentes e ainda assim estarem de acordo.

Assim, vamos supor que John, falante nativo do inglês, tenha reagido ao avistamento do cisne proferindo "Lo, a swan!". O factualista diria que, pelo fato de os dois proferimentos (na verdade os dois tipos distintos de proferimentos) estarem envolvidos em um mesmo tipo de cadeia causal, constituído pelos mesmos elementos, então os sujeitos que o produziram estão de acordo um com o outro. Agora, o que o factualista tem a dizer a respeito da semelhança entre os dois processos físico-causais envolvidos? Se eles são fundados em algum tipo de semelhança objetiva, então o fundamento do acordo é algo objetivo e transcendente as atitudes dos próprios sujeitos envolvidos na prática linguística, e dessa forma o factualista acaba sendo levado da intersubjetividade de volta para a boa e velha objetividade do significado.

E esse ponto não é alterado para a cláusula (ii). Pois, suponhamos que John 
também fale português, de modo que seu proferimento de "Lo, a Swan!" seja imediatamente seguido por "Olhe, um cisne". Para julgarmos que o segundo proferimento de John é uma instância do mesmo tipo que o proferimento de João devemos identificar da mesma forma similaridades objetivas entre eles - um mesmo padrão de sequências sonoras.

Uma vez retornando à objetividade do significado, com efeito, o cético pode questionar quais são os fatos constitutivos da semelhança entre tokens, ou entre circunstâncias. Em outras palavras, o que faz com que uma circunstância e outra sejam semelhantes para os nossos propósitos? Ou, o que faz com que dois tokens sejam de um mesmo tipo? O cético pode, por exemplo, levantar a hipótese de João querer dizer cisne por "cisne" e John querer dizer cisne branco por "swan" e por “cisne", uma vez que João não sabe que existem cisnes negros e só está disposto a fazer estes tipos de proferimento diante de cisnes brancos.

Um outro caminho para o social construtivista de estirpe factualista seria negar que essas semelhanças sejam objetivas. Ele poderia dizer: "Não importa se os proferimentos feitos por João e John concordam realmente ou não. Tudo o que importa é se João considera que o uso de John faz da expressão proferida concorda com os seus próprios usos; que ele pense haver uma 'convergência' entre os proferimentos." O social construtivista aqui inverte a prioridade explicativa: entenderíamos primeiro o que é um sujeito acreditar que $p$, para só então estarmos em condição de compreender $p$.

Mas, de acordo com Hattiangadi, tal estratégia falha ao incorrer em circularidade. Se a correção do proferimento de John depende do que João acredita sobre o proferimento de John, então o factualista antirrealista está pressupondo aquilo que ele está tentando explicar. Pois, para o proferimento de John estar correto, João terá de ter uma crença que tenha conteúdo independentemente da crença de John. Se a crença de João adquire seu conteúdo em função de um outro acordo prévio, digamos, com Maria, então Maria terá de ter uma crença anterior a qualquer acordo com João. Não importa quantos acordos existam, em algum ponto alguém terá de ter uma crença com conteúdo independente de outro acordo (HATTIANGADI, 2007 pp. 96-97).

A conclusão disso tudo é que o realismo semântico, da maneira como o definimos, é inescapável. Por um lado, o social construtivismo ou é inconsistente ou pressupõe disfarçadamente o realismo. Por outro lado, a conclusão cética é 
inaceitável, uma vez que ela nos deixa com um paradoxo no sentido mais forte do termo: a conclusão cética refuta a si própria. Assim, a inconsistência da tríade formada pelas teses do realismo semântico, da normatividade e do internalismo motivacional deve ser sanada ao voltarmos nossa atenção para essas duas últimas.

\subsection{Hattiangadi e a relatividade a normas}

A solução, para Hattiangadi, envolve precisamente negar a normatividade (N). Não seríamos obrigados a endossar $\mathrm{N}$ quando concebemos - como o fazemos trivialmente - que a significação linguística (e a intencionalidade em geral) é normativa no sentido de ser prescritiva. Sua proposta é a de substituir essa noção de normatividade $(\mathrm{N})$ por uma noção mais fraca, que ela chama de relatividade $a$ normas (2007, p. 7; pp. 179-208). Chamamos a relatividade a normas de Hattiangadi aqui de $\mathrm{N}^{*}$.

Apesar de Hattiagandi enxergar a substituição de $\mathrm{N}$ por $\mathrm{N}^{*}$ como a chave para o problema cético, o espaço que ela dedica à exposição de $\mathrm{N}^{*}$ em seu livro é surpreendentemente pequeno. De qualquer maneira, podemos seguramente afirmar que, de acordo com a filósofa indiana, algo é normativo no sentido fraco $\left(\mathrm{N}^{*}\right)$ se essa coisa está submetida a um certo padrão estabelecido, mas sem que daí possamos derivar por si só algum tipo de prescrição (2007, p. 7-8).

Por exemplo, o metro padrão de Paris é normativo no sentido de que é o padrão relativamente ao qual eu posso dizer que a mesa da minha cozinha tem um metro de profundidade. Mais interessantemente, é o metro de Paris que, em última análise, determina se a trena que eu uso para tirar a medidas da mesa está corretamente graduada ou não, ou se é ou não uma boa trena. Mas, o fato de eu estar empregando as noções de correção ou bondade para falar da trena não implica por si só qualquer tipo de obrigação a qual eu esteja submetido.

Com efeito, Hattiangadi pontua que os predicados "bom" e "correto" nem sempre são utilizados com um sentido normativo pleno:

(...) se eu digo "que a faca é boa", eu talvez queria dizer que ela é afiada e manuseável. "Esta faca é boa" não implica uma obrigação por si só, de modo que eu devesse trazer mais facas como essa à existência. Evidentemente, se eu quero cortar legumes como uma boa faca (i.e., com uma faca que seja manuseável e afiada), então o fato de que a faca é uma boa faca implica que eu devo usar a faca, mas somente dado o meu desejo de cortar vegetais; (...) o juízo de que a faca é afiada e manuseável não vai ser suficiente, por si só, para me motivar - como efetivamente acontece quando o que eu quero fazer é bater um ovo. (...) (2007, p. 59) 
O ponto de Hattiangadi é que quando "correto" ou "bom" não tem força normativa, algo ser bom ou correto não faz com que o sujeito deva fazer alguma coisa por si só. Transpondo as considerações para o nosso exemplo, a trena só é "corretamente" graduada dado o desejo de obter medidas de objetos físicos de acordo com um padrão amplamente compartilhado. Mas se ou não a trena está de fato graduada de acordo com o metro padrão de Paris é algo puramente descritivo. Vemos o que isso representa no âmbito da semântica quando percebemos que o contraste entre $\mathrm{N}$

( $s$ quer dizer $m$ por $e$ em $t) \rightarrow((s$ deve usar $e \leftrightarrow$ condições de correção são satisfeitas) em $t$ )

$$
\text { e } \mathrm{N}^{*}
$$

$(s$ quer dizer $m$ por $e$ em $t) \rightarrow(($ s usa $e$ corretamente $\leftrightarrow$ condições de correção são satisfeitas) em $t$ )

reside precisamente no modo como interpretamos a natureza das condições de correção para o uso de uma expressão $e$.

Normativistas pressupõem que a noção de condições de correção possui um status normativo básico; mas, para Hattiangadi (e outros adeptos de $\mathrm{N}^{*}$ ), falar em condições de correção é apenas uma forma mais genérica de falar de outros atributos semânticos que podem ser analisados eles mesmos em termos puramente descritivos. Esses atributos semânticos que figuram nas condições de correção são, para nenhuma surpresa, os atributos semânticos tidos como básicos para as teorias semânticas clássicas, a saber, verdade e referência (2007, p. 60). Assim, se estabelecemos que as condições de correção em questão são atribuídas ao uso de um predicado $\mathrm{F}$, por exemplo, podemos definir uma instância de $\mathrm{N}^{*}$ envolvendo $\mathrm{F}$ - vamos supor $-\mathrm{N}_{\mathrm{F}} *$ - que elimine qualquer vocabulário sugestivamente normativo:

$(s$ quer dizer $F$ por "F" em $t) \rightarrow((x)((" F "$ é verdadeiro de $x) \leftrightarrow F \mathrm{x})$ em $t)$

De certa forma, o diagnóstico de Hattiangadi é de que o WK só consegue nos impressionar com o seu problema cético porque ele nos induz a tentar explicar as condições de verdade de enunciados da forma "s quer dizer m por $e$ " como se 
elas fossem dadas por condições de correção ainda mais básicas e tidas como normativas em um sentido pleno, prescritivo. Uma vez que vemos que as condições de correção no uso de uma expressão não são nada além das condições de verdade (a partir das quais também é definida a referência dos termos singulares) e que não há nada como obrigações ou deveres "semânticos", o problema estaria resolvido.

Infelizmente, a solução proposta por Hattiangadi nos conduz de volta ao representacionismo - um traço das teorias clássicas do significado que identificamos, ao fim do primeiro capítulo, como nos deixando em graves dificuldades. Vimos que o representacionismo está associado, em metafísica, a um tipo de realismo muito encorpado de realismo - a objetividade da verdade - que é perigosamente vulnerável a formas mais tradicionais de ceticismo (ao problema do mundo exterior e das outras mentes). Por outro lado, tendo em vista os propósitos próprios de uma teoria semântica, a aceitação de enunciados cuja verdade transcendesse em princípio a toda evidência possível nos deixaria com um hiato entre a significação de uma expressão e a sua compreensão, manifestável em termos de comportamentos.

De qualquer modo, há ainda boas razões para supor que a proposta de Hattiangadi de trocar $\mathrm{N}$ por $\mathrm{N}^{*}$ é por si só suficientemente complicada. Em primeiro lugar, cabe o questionamento: $\mathrm{N}^{*}$ é realmente uma tese plausível para explicar o tipo de normatividade próprio da semântica e da intencionalidade? Suponhamos que alguém tenha posto em mim, sem que eu soubesse (talvez eu estivesse anestesiado), uma lente de contato que tivesse a inusitada propriedade de inverter o espectro da percepção de cores. Nessa situação, eu iria perceber algo azul como sendo verde e vice-versa. Suponhamos ainda que eu ficasse num quarto fechado onde eu não poderia me dar conta dessa inversão apenas raciocinando acerca do tipo de objeto que eu estou vendo (essa condição é necessária uma vez que, se eu fosse andar ao ar livre, me daria conta da inversão ao avistar o céu verde e as árvores azuis). Nesse tipo de cenário, parece que usar corretamente expressões de cores em qualquer sentido razoavelmente atribuível a noção de correção - não consiste em produzir enunciados verdadeiros. Ainda que estipulemos que as condições da correção são definidas em termos de condições de verdade em situações perceptuais adequadas; não é justo dizer que, se eu quero dizer verde por "verde", então, ao usar essa lente sem saber dentro do quarto fechado, é correto que eu diga, das coisas que eu percebo verdes, que elas são verdes? Não é razoável alegar que, se eu quero dizer 
verde por "verde", então eu de algum modo devo reportar os objetos azuis como sendo verdes, dado que eu assim os percebo?

Em segundo lugar, e em certa conexão com o ponto do parágrafo anterior, uma concepção de normatividade inteiramente desprovida de força deôntica é de fato inteligível? O movimento de Hattiangadi no que tange ao domínio especificamente semântico é que, do fato de que regras semânticas não são categóricas (não estamos obrigados a, toda vez que estivermos diante de um objeto verde, falar que ele é verde para que sejamos considerados como querendo dizer verde por "verde"), elas não seriam genuinamente prescritivas. No entanto, não é claro como o fato de uma regra não ser categórica - i. e., aplicável a todos os sujeitos em todos os casos independentemente do sujeito - implica que ela não tenha nenhuma força prescritiva. Com efeito, regras não categóricas parecem poder ser transformadas em regras categóricas uma vez que fazemos certas adaptações, assim como um raciocínio indutivo pode ser transformado em dedutivo se introduzirmos um princípio geral de indução empírica como premissa.

Suponhamos que eu queira ir a Ilha Grande pelo meio de transporte que seja o mais seguro e barato possível. Consultando um agente de viagens, eu descubro que o meio que é ao mesmo tempo seguro e barato é fazendo o percurso do continente até a ilha em uma barca. Ora, não é o caso que, nessa situação, dados o meu desejo de ir a Ilha Grande, o meu desejo de chegar a ilha da forma mais barata e segura possível, e o meu conhecimento de que a forma mais barata e segura de chegar à Ilha Grande é viajando em uma barca, eu esteja "obrigado pela razão", ceteris paribus, a tomar uma barca para ir a Ilha Grande? Se eu não tenho nenhuma outra atitude proposicional que interfira nesse arranjo, não é verdade que a razão me prescreve a ação que devo realizar?

Do mesmo modo, se eu estou disposto a ser sincero e estou em condições subjetivas adequadas e me perguntam quanto é $68+57$, então, se eu quero dizer adição por “+”, eu de fato sou "obrigado" a responder '125', sob pena de ser irracional. Retomando o vocabulário kantiano da Fundamentação da Metafísica dos Costumes, diríamos que imperativos podem ser hipotéticos do ponto de vista do dever moral, mas são sempre categóricos do ponto de vista da razão. "Todos os imperativos são expressos pelo verbo dever, e indicam desse modo uma lei objetiva da razão (...)" (KANT, 1993, p. 83).

Tendo em vista todos esses inconvenientes da solução proposta por 
Hattaigandi a nossa ideia neste trabalho é tomar o outro caminho: ao invés de rejeitar a normatividade em detrimento da relatividade a normas, adotar uma concepção de motivação alternativa àquela do internalismo motivacional sugerida acima. Hattigandi pressupõe uma concepção psicológica de motivação: estar motivado a fazer algo é semelhante a ter o desejo de fazer algo, no sentido de que um sujeito s está motivado a tornar p o caso quando ele tem uma disposição ou inclinação a tornar p o caso. A nossa proposta é não só endossar uma concepção forte de normatividade como também buscar uma explicação normativista para o que é ter um motivo: "s ter um motivo para tornar $p$ o caso" deve ser entendido não em termos (apenas) psicológicos causais, mas em termos de ter uma razão ou estar justificado a tornar $p$ o caso. 


\section{O quadro de uma teoria inferencialista do significado}

\subsection{Inferências e inferencialismo(s)}

Até agora, falamos do inferencialismo como uma estratégia em teoria do significado que se caracteriza por buscar explicar o papel representacional da linguagem (e indiretamente, do pensamento) a partir dos seus atributos inferenciais, considerados como sendo mais básicos. Colocando de um modo mais sistemático, dentro de uma teoria semântica inferencialista, o significado de uma expressão linguística (e o conteúdo dos atos mentais) é o seu papel em relações de inferência com outras expressões (e outros conteúdos de atos mentais). Nossa motivação para sondar uma abordagem inferencialista em semântica foi tentar evitar as dificuldades postas pela abordagem representacionista, especialmente no que diz respeito à sua costumeira associação com OV (objetividade da verdade) - a qual, por sua vez, é historicamente presa fácil para o ceticismo (cf. seção 2.2.3).

Dissemos, entretanto, muito pouco acerca de qualquer outra coisa importante e apenas delimitamos o tipo de inferencialismo a ser abordado aqui como sendo o "inferecialismo de Pittbsurgh" (o inferencialismo pragmáticonormativo aventado por Sellars e desenvolvido por Brandom). O presente capítulo é o lugar adequado para começar a aprofundar essas discussões.

Para começo de conversa, devemos esclarecer o que se entende pela noção de inferência, o que envolve determinar: o "ponto de partida" de uma inferência (do que se infere); o "ponto de chegada" de uma inferência (o que se infere) e; a própria forma da inferência (como se infere). Não menos importante, devemos também investigar de que maneira a relação inferencial entre aquilo do que se infere e aquilo que é inferido contribuiu para a significação de ambos os conteúdos.

Brandom fala em uma concepção estreita e uma concepção ampla de inferência. A concepção estreita considera que a relação inferencial ocorre sempre 
entre conteúdos conceituais - o que pode ser entendido em termos de enunciados e de expressões subsentenciais a nível da linguagem - ou em termos de crenças e conceitos - a nível do pensamento intencional. Isso significa dizer que tanto o ponto de partida quanto o ponto de chegada de uma inferência devem ser sempre enunciados ou crenças. O sentido estreito de inferência é o sentido que normalmente aparece nas definições de inferência nos manuais de lógica e teoria da argumentação: “(a) inferência é um processo pelo qual se chega a uma proposição, afirmada na base de uma ou outras mais proposições aceitas como ponto de partida do processo.” (COPI, 1978, p. 21) Já a concepção ampla admite que o movimento inferencial acontece não apenas de enunciados para enunciados (ou de crenças para crenças), mas também de circunstâncias perceptuais para enunciados e crenças, e de enunciados e crenças para ações (BRANDOM, 1994, p. 131).

Um inferencialismo que assume a concepção estreia de inferência é chamado de hiperinferencialismo (ibidem, p.131). Obviamente, essa é uma concepção restritiva demais para servir aos propósitos do tipo de inferencialismo que explique a significação dos termos das linguagens naturais; uma linguagem natural é formada em sua maioria por conceitos empíricos, isto é, conceitos cuja constituição tem necessariamente uma contribuição da experiência sensorial. Assim, analisar o significado de uma expressão linguística assumindo a concepção restrita é factível somente quando a expressão em questão pertence à linguagem utilizada por uma ciência formal, tal como a matemática.

A concepção ampla de inferência apresentada por Brandom é tributária ao que Sellars chama de tipos básicos dos "movimentos" de um jogo de linguagem: movimentos linguagem-entrada, linguagem-linguagem e linguagem-saída (SELLARS, 2007, p. 36). Os movimentos linguagem-entrada vão de uma experiência sensorial tida por um sujeito a, paradigmaticamente, o proferimento de um enunciado com status de relato observacional. Por exemplo, meu proferimento de "Está chovendo agora" tem o status de relato observacional se ele é induzido pela minha experiência perceptual, digamos, de ver as gotas caindo através da janela do meu quarto. Os movimentos linguagem-saída tipicamente vão de enunciados como "Eu vou levar o cachorro para passear" (cujo correspondente "interno" é uma intenção) para a série de comportamentos que consistem na ação de levar o cachorro para passear.

A concepção alargada não apenas serve para explicar a conexão dos 
conteúdos conceituais com o mundo, mas também para explicar outras conexões entre conteúdos conceituais e, indiretamente, entre expressões linguísticas. Assim, são também consideradas relações inferenciais por Brandom as relações de incompatibilidade entre conteúdos conceituais (por exemplo, a relação de exclusão mútua entre os predicados "estar vivo (em t)" e "estar morto (em t)" é tida como também inferencial) e mesmo relações anafóricas entre expressões linguísticas, como entre os tokens - por exemplo, os tokens "Maria" e "ela" no enunciado "A filha de Maria é médica e ela também".

Os portadores primários das relações inferenciais são enunciados, de modo que, em primeiro lugar, é o "conteúdo" (o conteúdo intencional, semântico, ou ainda a mesma coisa, a significação) dos enunciados envolvidos em uma relação inferencial que é constituída pela própria relação; expressões subsentenciais possuem significação inferencial apenas de uma maneira derivada, a partir da contribuição que elas dão aos atributos inferenciais dos enunciados nos quais elas ocorrem; nisso consiste o Princípio do Contexto dentro de uma teoria inferencialista. ${ }^{55}$ Além disso, o fato de que enunciados articulados inferencialmente são os portadores primários da significação linguística nos leva a outras três características destacáveis do inferencialismo: o materialismo inferencial, o holismo semântico e o expressivismo lógico.

Podemos entender o que é uma inferência material em contraste com o que costumeiramente se chama de inferência formal. Quando a bondade (correção) de uma inferência se constitui em função de sua forma, o que nós temos é algum tipo de processo de abstração que considera apenas uma parte do conteúdo dos enunciados envolvidos na inferência como determinando a sua bondade. Na lógica proposicional, por exemplo, todo o conteúdo subsentencial de enunciados simples é desconsiderado, e as inferências são avaliadas como sendo boas ou ruins apenas em função do conteúdo dos operadores verofuncionais. "Não é o caso que não está chovendo" tem como consequência lógica "Está chovendo" apenas pelo "comportamento" lógico da negação, de modo que o assunto do qual os enunciados tratam não tem nenhuma relevância em relação à bondade dessa inferência. Mas, quando inferimos "Isto não é verde" a partir de "Isto é vermelho", a

\footnotetext{
${ }^{55}$ De acordo com Stainton (2006, pp. 192-193) o inferencialismo está comprometido com aquilo que ele chama de interpretação metassemântica do Princípio do Contexto. Outras abordagens para teorias semânticas obviamente estão comprometidas com interpretações diferentes do princípio.
} 
bondade dessa inferência se constitui inteiramente pelo conteúdo não (formalmente) lógico dos enunciados; especificamente, a bondade da inferência se constitui pela natureza dos predicados envolvidos. Diríamos que tais predicados são materialmente incompatíveis: ao dizermos, de um dado x, que ele é (totalmente) verde, então, concluímos que x não pode ser também (totalmente) vermelho, pois dois predicados de cor não podem ser satisfeitos por um mesmo objeto ao mesmo tempo.

A maioria dos teóricos, entretanto, rejeitaria essa noção de inferência material como sendo supérflua. Eles insistiriam que a bondade da inferência de "Isto é verde" para "Isto não é vermelho" deve se dar apenas em função do vocabulário lógico, supondo que tal inferência envolva uma premissa "escondida" contendo um condicional: "Se algo é (totalmente) verde, então não é (totalmente) vermelho". Para esta posição, chamada de formalismo inferencial, toda correção inferencial é explicada em termos puramente formais - envolvida em um argumento válido.

Já o materialismo inferencial não só sustenta que existem inferências materiais genuínas como também que, em última análise, são as inferências formais que são redutíveis às materiais - isto é, inferências materiais são explicativamente mais básicas que as formais. ${ }^{56}$ Para o materialista inferencial, a inferência de "Isto é verde" para "Isto não é vermelho" estaria longe de ser entimemática; ao invés disso, ela seria (parcialmente) constitutiva do próprio conteúdo dos predicados envolvidos.

Brandom apresenta o expediente que precisamos para gerar inferências formais a partir de inferências materiais (1994, pp. 104-105):

Tudo do que se precisa é uma partição do vocabulário em dois tipos: aqueles que devem ser considerados fixos e aqueles que devem ser considerados como substituíveis. Chame o vocabulário que deve ser fixado de vocabulário-K. A estrutura geral das definições de formalidade é então que o conjunto de inferências $K$-válidas (aquelas que serão entendidas como boas em virtude apenas da sua forma- $K$ ) inclui aquelas que satisfazem as duas condições de serem inferências que (1) são boas inferências e (2) não podem ser transformadas em más inferências ao substituir vocabulário não-K por não-K.

Em outras palavras, uma vez que tenhamos separado o vocabulário de nossa linguagem em K e não-K, devemos tomar os enunciados corretamente usados onde o vocabulário-K ocorre e considerar as relações inferenciais materiais entre tais

${ }^{56}$ A ideia do formalismo inferencial de que as inferências supostamente materiais são sempre inferências formais entimemáticas é por si só problemática. Quine (1930) pode ser visto como argumentando que essa posição conduz a um regresso ao infinito de "explicitações" de entimemas quando essa ideia é utilizada para estabelecer o significado dos próprios operadores lógicos. 
enunciados. As inferências K-formalmente válidas são então definidas como sendo aquelas cuja bondade é preservada ao trocarmos uma expressão subsentencial nãoK por outra expressão não-K diferente. No caso limítrofe, se todo o vocabulário de uma linguagem é considerado $\mathrm{K}$, então nessa linguagem só há inferências materialmente boas.

De acordo com Brandom, esse expediente explica bem o que Frege realiza na sua Conceitografia. (ibidem, pp. 94-95). Frege define o conteúdo de uma expressão subsentencial como o papel inferencial que ele desempenha nos enunciados dos quais ela participa. Então, Frege toma como vocabulário-K as expressões "se... então"," não" e "todo" e sinônimos e identifica as inferências Kformalmente boas como sendo as inferências logicamente válidas (no âmbito das ciências formais).

De fato, este ponto está intimamente conectado com aquilo que elencamos na introdução como um dos elementos estruturantes do inferencialismo de Pittsburgh, a saber, a doutrina do expressivismo lógico:

(...) a importância filosófica da lógica não é que ela permite aqueles que dominam o uso das locuções lógicas provar uma classe especial de alegações (...). A importância do vocabulário lógico está, ao invés disso, no que ele permite aqueles que o dominam dizer - a classe especial de alegações que ele permite expressar. (ibidem, Prefácio, xix)

Em outras palavras, a genuína importância da lógica para a filosofia não é que ela estabeleça os critérios de correção para avaliação dos raciocínios filosóficos, ou permita os filósofos arregimentar mais claramente as suas teses. Embora essas possam ser consequências úteis para os filósofos ao exercerem a sua atividade, o expressivista insistiria que o verdadeiro valor da lógica para a filosofia está em permitir explicitar, através do uso do vocabulário lógico, a estrutura da linguagem e do próprio pensamento, de modo geral, e os conteúdos conceituais das expressões, de modo particular (cf. 4.4 e 4.5 abaixo).

Com efeito, o jovem Frege (décadas de 1870 e 1880) é visto por Brandom como um legítimo inferencialista e expressivista lógico. O expressivismo de Frege consiste na criação de uma linguagem formal cuja notação explicitasse o papel inferencial desse vocabulário lógico, diferenciando o vocabulário lógico do vocabulário não-lógico. A Conceitografia de Frege obviamente não inventou nem a lógica nem o vocabulário lógico, mas, por essa leitura histórica de Brandom, ela inventou uma linguagem simbólica que tornasse explícita a forma lógica das linguagens naturais (ao menos a parte da linguagem natural utilizada nas ciências 
formais, que é extensional). ${ }^{57}$

Notemos que o sentido de "lógico" do expressivismo lógico de Brandom é amplo. Como apontamos no capítulo 2, não estamos restritos a tratar apenas os termos lógicos extensionais como sendo lógicos, mas também os termos ditos intensionais, o que envolveria, por exemplo, vocabulário modal alético, epistêmico, deôntico etc. Nesse sentido, se a nossa característica universal explicita em sua notação esses vocabulários (na forma de operadores, de termos cuja significação é previamente fixada), então esses vocabulários são também lógicos (isto é, o expressivismo modal alético, epistêmico, deôntico etc são todos espécies de expressivismo lógico).

Agora, uma consequência natural do inferencialismo é o holismo semântico. Considerando que conceitos são expressos linguisticamente por expressões subsentenciais de uma característica universal, e que é o papel que elas desempenham em inferências envolvendo certos enunciados aquilo que constitui o conteúdo semântico ou intencional (ou o que é ainda a mesma coisa, a significatividade) de tais expressões, então a compreensão de uma única expressão e a aquisição de um único conceito por um sujeito - correspondente à expressão em questão - é impossível. Nas palavras de Brandom (1994, p. 89):

(...) apreender um conceito envolve dominar as adequações de movimentos inferenciais que conectam ele a muitos outros conceitos: aquele cuja aplicabilidade se segue do conceito em questão, e aqueles cuja aplicabilidade a aplicabilidade do conceito alvo se segue, e aqueles cuja aplicabilidade preclui ou é precluída por ele.

Isso é fácil de ver utilizando, mais uma vez, um exemplo com cores. Não é possível compreender o conceito de vermelho sem dominar pelo menos as principais relações inferenciais que o constituem; por exemplo, saber aplicar o conceito a objetos em relatos observacionais (e crenças perceptuais), saber que se algo é vermelho, então esse objeto possui uma cor, saber que se algo é (totalmente) vermelho em um momento, então não pode possuir qualquer outra cor. ${ }^{58}$

\footnotetext{
57 Esses apontamentos históricos de Brandom fazem dos textos do jovem Frege uma espécie de "ponto de partida" para um teórico inferencialista do significado do mesmo modo que os textos do Frege maduro são o "ponto de partida" para os teóricos do significado que chamamos de clássicos.

${ }^{58} \mathrm{O}$ holismo semântico do inferencialismo é considerado uma forma fraca de holismo; ele sustenta que o aprendizado linguístico-conceitual se dá pela aquisição de baterias ou blocos de conceitos, cuja compreensão dos conceitos que compõem cada um desses é interdependente. Alguns desses blocos são mais básicos que outros, no sentido de que eles são os primeiros a serem aprendidos e sem eles não ser possível adquirir outros menos básicos. O holismo fraco costuma contrastar com o holismo forte - frequentemente atribuído a Quine, Davidson e teóricos coerentistas da verdade - no qual a compreensão de uma expressão depende da compreensão de todas as outras expressões
} 
Cabe ainda fazer uma especificação a respeito da maneira como as relações inferenciais constituem o conteúdo semântico de uma expressão linguística. Como foi salientado na introdução, o escopo deste trabalho abrange o que estamos chamando de inferencialismo pragmático-normativo ou inferencialismo de Pittsburgh - baseado notadamente nas obras de Sellars e Brandom. Nesse inferencialismo, as relações inferenciais que constituem o conteúdo semântico de expressões de uma linguagem são regras - elas estipulam como uma expressão deve ser corretamente utilizada pelos sujeitos usuários dessa linguagem - em um sentido de "regra" e "correto" que é inteiramente normativo (como oposto ao normativo como relativo a normas, que víamos no cap. 2). Tais regras são verbalmente expressas por aquilo que o $2^{\circ}$ Wittgenstein chamou de enunciados gramaticais (Investigações, §458), e que Sellars chamou de sentenças primitivas “incondicionalmente asseríveis" (2007, p. 37) - dado que para elas não há qualquer restrição às suas circunstâncias de aplicação (i. e., elas não são inferidas a partir de nada e o proferimento delas por um sujeito, em qualquer circunstância, é trivialmente verdadeiro).

Mas há também aquilo que Peregrin (2014, pp. 8-10) chamou de inferencialismo causal no qual os papeis inferenciais das expressões linguísticas são identificados com papeis causais e disposicionais que elas desempenham na mente de um sujeito. Em tal tipo de teoria inferencialista - defendida por Boghossian e Peacocke no início dos anos 1990 - as inferências constitutivas do significatividade são dadas em termos não do que os sujeitos devem fazer, mas do que eles efetivamente fazem, de modo que aparentemente, a semântica e mesmo a lógica são reduzidas às ciências cognitivas. ${ }^{59}$

Essa vertente de abordagem inferencialista opta por uma noção fraca de normatividade - a relatividade a normas da qual falamos no final do último capítulo.

\footnotetext{
daquela linguagem. O holismo fraco é chamado por Dummett (EVANS \& MCDOWELL, p. 72) de molecularismo e é também compatível com o representacionismo.

${ }^{59}$ A rigor, o significado das expressões das linguagens naturais (e consequentemente do "logiquês") seria dado, nessas teorias, apenas indiretamente. As "semânticas dos papeis inferenciais", como foram chamadas tais teorias, seguem o tipo de funcionalismo proposto por Fodor, no qual haveria uma "linguagem do pensamento", e uma espécie de código-máquina, de linguagem de baixo-nível de seres inteligentes. Uma linguagem natural seria correlacionada estrutural e causalmente à linguagem do pensamento do mesmo modo que linguagens de programação como Java ou Python estão estrutural e causalmente correlacionadas com o código binário que é "entendido" pelo hardware de um computador.
} 
Uma vez que lá assumimos uma posição favorável ao normativismo, nossa opção pela vertente pittsburghiana de abordagem inferencialista se torna justificada. Ademais, dado que no inferencialismo a noção de inferência deve ser o ponto de partida explicativo para o restante da semântica, seria de se esperar que ela fosse invocada para explicar a noção de causalidade ao invés do contrário. Pende sobre o inferencialismo causal, dessa forma, uma suspeita de circularidade (invocar a noção de causalidade para explicar a noção de inferência para depois explicar a noção de causalidade em função da noção de inferência), ou, alternativamente, de uma retorno sub-reptício ao representacionismo (definir causalidade pressupondo que noções referenciais estejam inteiramente explicadas, tornando o inferencialismo uma abordagem supérflua).

\subsection{Teoria da prática, pragmática e semântica}

Em uma teoria semântica, aspectos semânticos costumam ser mais fundacionais do que os aspectos pragmáticos: uma teoria da força e uma teoria dos atos de fala costumam ser desenvolvidas como um complemento às teorias da referência e do sentido. No entanto, na esteira do célebre Princípio do Contexto, parece que o mais correto é tratarmos a semântica como sendo interdependente em relação à pragmática. Em 2.2.1 estabelecemos que a força assercional tem uma primazia sobre as demais, na medida em que as outras forças podem ser explicitadas em asserções, mas não o contrário. No logiquês, a significação de uma expressão subsentencial - seja ela compreendida primariamente em termos de referência ou papel inferencial - é dada necessariamente em enunciados, ou seja, em sentenças com força assercional. Assinalando esse ponto de outro modo, podemos dizer: dado um conjunto de diferentes enunciados, são os aspectos semânticos que fazem com que os enunciados se diferenciem entre si, mas são aspectos pragmáticos que fazem com que todos esses enunciados sejam enunciados.

Apesar da interdependência, na teoria inferencialista de Brandom há ao menos uma certa conveniência em atribuir algum grau de prioridade explicativa à pragmática. Embora sua pragmática normativa não possa ser bem entendida sem levarmos em consideração a noção de conteúdo inferencial de uma sentença, o desenvolvimento pleno da semântica inferencialista depende de um desenvolvimento pleno da pragmática normativa, mas não o contrário; em outras palavras, os termos da semântica inferencialista são todos definidos em termos da 
pragmática normativa, mas os termos desta última (especialmente o caráter normativo) podem ser entendidos de um modo mais ou menos independente dos termos da semântica.

É importante salientar que a pragmática de Brandom vai muito além de uma teoria da força ou dos usos comunicacionais da linguagem. A pragmática de Brandom engloba uma teoria da prática normativa - uma teoria a respeito do que consiste um conjunto de sujeitos tratando as performances (qualquer que seja a natureza dessas performances) uns dos outros como sendo passíveis de serem avaliadas como corretas ou incorretas em função de regras. ${ }^{60}$ Com efeito, é um ponto crucial do programa teórico de Brandom mostrar que, no final das contas, os elementos básicos da sua pragmática (a sua teoria da prática) são elementos de uma teoria da força justamente porque podemos estruturar uma teoria semântica - uma teoria do conteúdo representacional - a partir deles.

Brandom concebe uma prática como formada por sujeitos que possuem compromissos para realizar determinadas performances. Tais sujeitos podem estar, em relação a esses compromissos, comprometidos a, habilitados a, ou preclusos de possuí-los. ${ }^{61}$ Compromissos para com a realização de performances, e a condição de um sujeito estar habilitado ou precluso de possuí-los, são chamados por Brandom de status deônticos. Os status deônticos são instituídos por atitudes práticas assumidas pelos próprios sujeitos uns em relação aos outros; o conjunto de status deônticos possuído por cada sujeito em um determinado momento é chamado de pontuação deôntica, de modo que, tipicamente, a pontuação é alterada em função de performances que os sujeitos da prática venham ou não a realizar.

Esses conceitos técnicos normativos trazidos por Brandom são considerados como sendo fundamentais ou primitivos: eles não podem ser explicados através de uma definição analítica, ou de uma análise redutiva. Em realidade, a proposta do inferencialismo - especificamente de Brandom - é justamente definir os conceitos

\footnotetext{
${ }^{60}$ Brandom usa o termo "regra" de um modo estrito, para se referir apenas a regras paras as quais os sujeitos dispõem de uma formulação verbal explícita. No presente trabalho, preferimos seguir o restante da literatura e aplicar o termo tanto a regras explícitas quanto implícitas.

${ }^{61}$ Apesar do modo de expressão de Brandom sugerir uma primazia dos compromissos e habilitações em relação as preclusões, o conceito de preclusão têm de estar no mesmo patamar. Isso porque estar precluso a fazer alguma coisa não pode ser definido como "não estar habilitado a...", pois a introdução da negação só ocorre numa etapa posterior da sua teoria semântica. Dizemos simplesmente que o compromisso com uma coisa exclui outros compromissos.
} 
intencionais (crença, verdade, significação, representação, entre outros) em termos da teoria da prática normativa. Conceitos normativos são logicamente anteriores a qualquer explicação que possamos dar sobre qualquer coisa, e o único tipo de análise filosoficamente proveitosa que podemos oferecer para eles é aquilo que Strawson (2002, pp.35-37) chamou de análise conectiva: entender como tais conceitos se relacionam entre si e com outros conceitos, através de experimentos mentais que ponham em evidência as características que lancem luz sobre as conexões que estamos interessados em ressaltar de acordo com nossos propósitos.

Agora, que o caráter normativo da linguagem (e do pensamento) seja explicado em função de uma teoria da prática normativa não implica que esse caráter normativo tenha uma fonte ou origem anterior à própria linguagem. $\mathrm{Na}$ verdade, como colocamos mais adiante, o inferencialismo de fato sustenta que o caráter normativo da linguagem é mesmo fundamental. Como pontuamos no próximo capítulo, ainda que possamos tratar performances de seres não linguísticos como sendo corretas ou incorretas, e mesmo, talvez, considerar tais seres como se engajando em uma prática genuinamente normativa, isso só é possível a partir da projeção de atitudes práticas a tais seres por seres que de fato possuem linguagem isto é, que possuem uma linguagem sintaticamente articulada e expressivamente rica o suficiente para possuir um vocabulário semântico.

\subsubsection{Registro de pontos e o jogo das fichas coloridas}

Brandom explica os seus conceitos técnicos normativos tendo em vista o que ele chama de jogo dos registradores (scorekeeping game) (1994, p.182). A ideia-chave de Brandom aqui é que cada sujeito acompanha minunciosamente (keep track) através de registros a sua própria pontuação deôntica, bem como a pontuação de todos os outros sujeitos. Cada sujeito orienta suas próprias performances, bem como avalia as performances dos demais, levando essas pontuações em consideração (1994, p. 183):

Pontuações deônticas consistem em constelações de compromissos e habilitações por parte de vários interlocutores. Assim entender ou apreender a significação de um ato de fala exige ser capaz de relatar em termos de tais pontuações quando seria apropriado (circunstâncias de aplicação) e como seria transformar a pontuação caracterizando o estágio na qual ela é realizada na pontuação obtida no próximo estágio da conversação na qual ela é uma parte (consequências de aplicação). Para cada estágio, o que alguém está permitido ou obrigado a fazer depende da pontuação (...). Ser racional - entender, saber como no sentido de ser capaz de jogar o jogo de dar e pedir por razões - é dominar na prática a evolução da pontuação. Falar e pensar é registrar os pontos (keeping score) neste tipo de jogo. 
O experimento mental apresentado nessa subseção - que chamamos de jogo das fichas coloridas - deve ser interpretado como um mero desenvolvimento do jogo dos registradores, visando dar mais vivacidade a essa ideia e com isso uma maior clareza a respeito dos conceitos que informam a noção de prática normativa.

Imaginemos a seguinte situação. Em uma espécie de grande sala há várias cabines, cada qual com um painel, voltado para fora, para a audiência - e várias tabuletas - voltadas para dentro, para o ocupante da cabine. Em cada cabine, há uma provisão de fichas coloridas, que podem ter três formas geométricas: círculos, quadrados e triângulos. Além disso, as cabines são equipadas também com campainhas que podem ser tocadas por esses jogadores. O jogo é dividido em rodadas, e as rodadas são, por sua vez, divididas em turnos, tantos quanto sejam o número de jogadores e cabines individualmente ocupadas por eles. Toda comunicação entre os jogadores é realizada apenas por meio do uso dos próprios materiais do jogo. Podemos supor, então, que nós estamos na posição de um observador externo incumbido de descobrir qual a estrutura e quais são as regras do jogo a partir das performances dos jogadores envolvendo os materiais do jogo. Para facilitar as coisas, vamos imaginar que há apenas três jogadores (cada um em suas respectivas cabines) na sala: A, B e C.

Notamos que, nos seus respectivos turnos, os jogadores afixam ou não um círculo colorido no painel de suas cabines. Este é o principal tipo de lance do jogo, e para simplificar a nossa descrição vamos dizer que realizá-lo é jogar uma cor. Quando (no seu turno) um jogador jogar uma cor, os outros jogadores imediatamente colocam um quadrado daquela mesma cor em uma das tabuletas. Por exemplo, se A, no seu turno, joga amarelo, B e C, ainda no turno de A, afixam (cada um reservadamente, e sem qualquer tipo de sinalização aos outros dois jogadores) um quadrado em uma das tabuletas que ficam dentro da cabine.

As fichas coloridas representam compromissos que os jogadores atribuem a si e aos outros, enquanto o painel e as tabuletas funcionam como placares, onde são registradas as pontuações (conjuntos de status deônticos) de cada jogador. Com o painel principal, cada jogador exibe para os demais a pontuação que eles atribuem a si próprios, enquanto com as tabuletas os jogadores registram a pontuação dos outros dois jogadores, com base na configuração que cada jogador dá ao seu painel. Assumir (undertake) um compromisso (jogar uma cor) é a mesma coisa que atribuir um compromisso a si próprio. 
Nas tabuletas também são afixadas as fichas com formato triangular. Os círculos e quadrados simbolizam compromissos, mas os triângulos representam preclusões de compromissos - isto é, os compromissos que o jogador de quem a tabuleta é placar está proibido de assumir, tendo em vista os quadrados que nela aparecem.

Os jogadores jogam as cores e registram as jogadas uns dos outros nas tabuletas de acordo com as relações entre os compromissos sinalizados pelas cores. O jogar uma cor pode comprometer e/ou proibir esse jogador de jogar outras cores. Quando um jogador adquire um compromisso em função da posse de outros compromissos, dizemos que ele adquire um compromisso por herança (inheritance).

Suponha que na rodada seguinte àquela em que A jogou amarelo, A jogue vermelho. Como é de se se esperar, $\mathrm{B}$ e $\mathrm{C}$, ainda no turno de $\mathrm{A}$, afixam um quadrado vermelho nas suas respectivas tabuletas para A. Mas, além disso, B e C também põem um quadrado laranja com uma fita na tabuleta para A. A presença de um círculo amarelo e outro vermelho no painel de A o compromete a colocar, na rodada seguinte, um círculo laranja. As fitas apensadas aos quadrados laranjas afixados por B e C, que servem para indicar esse compromisso de A, são retiradas na rodada seguinte se A de fato jogar laranja; fitas presas nas fichas indicam que o compromisso que aquela ficha representa não é (pelo menos não ainda) assumido por aquele a quem o compromisso é atribuído.

Mas vamos supor que A, tendo um círculo amarelo e outro vermelho em seu painel, não jogue laranja na próxima rodada. Nesse caso, B e C, antes que o turno de A termine, irão tocar uma vez suas respectivas campainhas. O jogador A poderá então reagir de quatro formas: (i) ele retira a ficha amarela de seu painel; (ii) ele retira a ficha vermelha de seu painel; (iii) ele põe a ficha circular laranja em seu painel; ou (iv) ele não faz nada. Nesse último caso, o jogo continua, mas toda vez que for o início do turno de A nas rodadas seguintes, B e C tocarão a campainha, com esse padrão permanecendo até que A realize uma das três outras performances e "regularize" a sua pontuação.

Constatamos não apenas relações entre compromissos com os toques da campainha, mas também entre compromissos e preclusões de compromissos. Imaginemos um cenário um pouco diferente agora: ao invés de jogar vermelho na segunda rodada, A põe em seu painel um círculo cinza; a essa jogada, B e C reagem 
imediatamente realizando dois toques consecutivos em suas respectivas campainhas. Novamente, algumas opções se abrem para A: ele pode retirar o círculo amarelo que havia colocado na primeira rodada, ou pode retirar o círculo cinza que acabou de pôr. De maneira semelhante ao exemplo anterior, se A não realizar nenhuma dessas performances, então, no início do seu turno na próxima rodada, B e C vão tocar a campainha duas vezes seguidas. Apreendemos, dessa forma, que o compromisso indicado por ter um círculo amarelo no painel é incompatível com o compromisso indicado por ter um círculo cinza nesse mesmo painel.

Antes de prosseguirmos com a nossa explicação a respeito de como uma teoria inferencialista do significado tem os elementos de uma teoria da prática normativa como estruturantes (tanto na dimensão da teoria semântica quanto da teoria fundacional) cabem três observações a respeito do jogo das fichas coloridas.

Primeiro, o jogo não tem, e não precisa ter, um árbitro - isto é, um sujeito que intervém no jogo para validar ou invalidar os lances dos jogadores baseandose em um "livro de regras". Obviamente, os jogadores podem, vez ou outra, se equivocar e realizar performances que contrariam as regras do jogo. Mas também os árbitros são passíveis de cometerem erros! Árbitros especializados existem nos nossos jogos reais apenas como uma conveniência de prática, para reduzir a chances de violações de regras por equívocos ou conluio em eventos oficiais. Como bem vimos no capítulo anterior, toda regra é em princípio passível de ser mal aplicada ou mal interpretada, de modo que, do ponto de vista teórico, acrescentar um árbitro ao jogo não resolve em nada o problema do regresso ao infinito de interpretações.

Mas o que acontece quando um jogador passa a realizar com uma frequência muito alta performances que não são válidas ou contrariam as regras do jogo? A ideia é que quando isso ocorre, os outros jogadores deixam paulatinamente de considerar suas performances como modificando o seu próprio status deôntico, e, terminam por nem mesmo considerá-lo mais um jogador. Retomando as hipóteses de parágrafos anteriores, se A não responde corretamente aos desafios de B e C (seja retirando ou adicionando círculos de cores que ele está precluso ou comprometido a jogar), então $\mathrm{B}$ e $\mathrm{C}$ começam a não mais registrar o placar de $\mathrm{A}$ nas suas respectivas tabuletas para $\mathrm{A}$. Tal situação é semelhante àquela que acontece quando uma criança é excluída de uma brincadeira por ficar inconformada com os resultados e começa a desobedecer às próprias regras do jogo.

Agora, se a maioria dos jogadores começa a ter comportamentos 
predominantemente desviantes, então o próprio jogo enquanto prática se torna inviável. Diríamos nesse caso que as coisas as quais chamávamos de jogadores não são mais efetivamente jogadores daquele jogo, e não interpretamos mais suas performances como constituindo atitudes práticas. Só há prática, só há jogo, porque os sujeitos estão propensos a reconhecer quando eles estão ou não efetivamente comprometidos a realizar uma performance, ou seja, quando eles estão comprometidos a, habilitados a e preclusos de possuir compromissos.

A segunda observação diz respeito ao caráter social de uma prática normativa. Nosso experimento mental não pressupõe que toda prática normativa se constitua necessariamente por vários sujeitos. Embora algo como um argumento da linguagem privada seja desenvolvido mais adiante neste e no próximo capítulo, o jogo das fichas coloridas é um jogo multiplayer porque paradigmaticamente, jogos são multiplayer; práticas normativas são paradigmaticamente sociais. Tal como a argumentação de Wittgenstein nas Investigações, nossa argumentação parte do paradigma de uma prática como prática social e então questiona se esse caráter social é um elemento necessário do próprio conceito de prática social.

A terceira observação é que a versão do jogo das fichas coloridas esboçada até agora é a versão básica. Por exemplo, nessa versão todos os jogadores têm uma habilitação por default (BRANDOM, 1994, pp. 177-178): lhes é permitido jogar qualquer cor que não esteja precluída pelas cores jogadas por eles anteriormente. Assim, B e C consideram que A está habilitado a jogar qualquer cor que não apareça como ficha triangular nas suas respectivas tabuletas para A. Por outro lado, há aí envolvido um único tipo de herança de compromisso, que é a herança intrapessoal interconteúdo (ibidem, p. 175): todos os compromissos e preclusões de compromissos de um determinado jogador só dizem respeito a ele próprio. Por exemplo, todos os compromissos (e preclusões de compromissos) de A dependem tão somente das regras do jogo e das fichas que ele próprio põe em seu painel ao longo do jogo. Se B jogar uma cor precluída para A, de acordo com o registro de pontos que $\mathrm{B}$ faz para $\mathrm{A}$, mas não precluída para o próprio $\mathrm{B}$, o jogo segue normalmente, sem que nenhum dos dois desafie o outro tocando a campainha.

Entretanto, habilitação por default e heranças intrapessoais interconteúdo não são, obviamente, as únicas mecânicas para este jogo. Em 4.3 complicamos ambas as mecânicas e introduzimos novos elementos ao jogo para que ele se torne 
um modelo mais aproximado da prática discursiva que constitui o uso das linguagens naturais.

\subsubsection{Da teoria da prática à pragmática normativa e a semântica inferencial \\ Uma vez que os elementos estruturantes da teoria da prática de Brandom} foram apresentados por meio do jogo das fichas coloridas, estamos em condições de definir de modo mais sistemático os elementos estruturantes da teoria semântica de Brandom - e por extensão, de uma teoria semântica genérica do inferencialismo. Tendo isso em vista, podemos perguntar então: o que diferencia uma prática como essa de uma prática discursiva? A ideia é que os compromissos envolvidos em uma prática discursiva propriamente dita tem conteúdo intencional: eles pretendem nos permitir representar a realidade, e, gostaríamos de dizer, eles de fato nos permitem representar a realidade tal como é com grande frequência.

Proposições são compromissos com conteúdo intencional; elas estão para a teoria semântica inferencialista exatamente como as cores estão para o jogo das fichas coloridas. Alegações (claims) ou asserções constituem o ato de fala fundamental, por meio do qual um sujeito assume um compromisso com um conteúdo intencional (ibidem, p. 167); fazer uma alegação está para a pragmática normativa assim como jogar uma cor (afixar uma ficha colorida no seu próprio painel) está para o nosso jogo; ambas as performances envolvem utilizar explicitamente um token material para simbolizar o compromisso que está sendo assumido. Uma sentença (escrita ou falada) da linguagem natural, qualquer que seja o seu modo, está para a teoria semântica assim como uma ficha está para o jogo das fichas coloridas.

Um sujeito atribuir uma crença a outrem equivale a um jogador afixar um círculo colorido na tabuleta que este usa para registrar os compromissos de outro jogador. Toda crença é asserível e toda asserção tem a pretensão de expressar uma crença. Não por acaso, compromissos com conteúdo intencional são chamados por Brandom de compromissos doxásticos; julgar é modelado em termos de asserir. ${ }^{62}$

\footnotetext{
${ }^{62}$ Aqui há evidentemente uma diferença entre o jogo das fichas e a linguagem. Podemos reconhecer compromissos sem necessariamente ter de expressá-los através de uma alegação. No nosso jogo, a única maneira através da qual um jogador pode reconhecer um compromisso é jogando uma cor afixando um círculo colorido no seu painel. Mas na linguagem, podemos reconhecer compromissos sem necessariamente ter de expressá-los através de uma alegação - através de um proferimento in foro interno, por exemplo. Por outro lado, no nosso jogo, toda assunção de compromisso é pública e toda atribuição de compromisso (e preclusão de compromisso) é não manifesta (as tabuletas são voltadas para dentro da cabine). No entanto, obviamente também é possível na linguagem atribuir
} 
As relações inferenciais que constituem um compromisso doxástico são definidas em termos das pontuações deônticas nas quais os sujeitos estão habilitados a assumir tal compromisso, bem como das alterações na pontuação que se seguem dessa assunção. A transmissão de compromissos (e habilitações a e preclusões de compromissos) ocorre, em seu nível mais fundamental, por herança intrapessoal e interconteúdo, tal como em nosso jogo.

O valor cognitivo (o sentido fregeano) de um enunciado é, desse modo, dado pelo feixe de relações inferenciais que o constitui, assim como o valor de uma ficha colorida no jogo das fichas coloridas é dado pelas configurações do painel que habilita o jogador a jogar aquela ficha, bem como a configuração que o painel deve ganhar na rodada seguinte após tal ficha ser jogada. Poderíamos resumir essa ideia dizendo que o sentido de uma expressão linguística qualquer é dado pelas circunstâncias de adequação do seu uso, por um lado, e pelas suas apropriadas consequências de aplicação, por outro (ibidem, p. xiii) ${ }^{63}$.

Os tipos básicos de transições inferenciais na semântica inferencial - a saber, transições linguagem-linguagem, linguagem-entrada e linguagem-saída podem ser definidos a partir de agora à luz dos aspectos da teoria prática de Brandom, e dos elementos ressaltados no jogo das fichas.

\subsection{Transições inferenciais básicas}

\subsubsection{Transições linguagem-linguagem}

Movimentos linguagem-linguagem, isto é, de um enunciado para outro (cuja contraparte in foro interno são os movimentos de juízos a juízos) são o paradigma de movimento inferencial. No jogo das fichas, eles são ilustrados pelos lances que os jogadores são comprometidos a e proibidos de fazer, conforme a configuração

\footnotetext{
crenças a outrem através de alegações manifestas. Imaginemos então uma variante desse jogo, em que qualquer atribuição de compromisso - seja a si próprio ou a outrem - é publicamente manifesta: todo o registro de pontos é feito em tabuletas, e todas as tabuletas são visíveis para todos os jogadores. $\mathrm{O}$ fato de que um tal jogo seria de fato menos complexo do que a versão que havíamos apresentado em 4.2.1 nos ajuda a entender que a asserção - enquanto manifestação e explicitação de uma crença - tem uma certa prioridade lógica em relação à crença não manifesta.

${ }^{63}$ Nos parece que uma semântica inferencialista deve ser bidimensional. Dado que as sentenças declarativas devem possuir um valor de verdade enquanto valor semântico, só resta ao seu potencial inferencial se encaixar na dimensão do valor cognitivo - exercendo a função teórica do sentido fregeano.
} 
dos seus respectivos painéis em um dado momento do jogo. Dois pontos a respeito das inferências intralinguísticas nas linguagens naturais, entretanto, não encontram um paralelo direto em nosso experimento mental: a ocorrência de heranças de habilitação a compromissos e a ocorrência de heranças interpessoais intraconteúdo.

As inferências preservadoras de compromisso possuem uma pretensão de bondade que é absoluta - ou jure et jure (BRANDOM, 1994, p. 168). Por exemplo, se eu julgo que um dado triângulo é equilátero, então eu necessariamente devo estar pronto para julgar que ele tem ângulos iguais. Não há como essa inferência ser boa e ainda assim a minha transição linguagem-linguagem ser boa.

Já as inferências preservadoras de habilitação possuem uma pretensão de bondade relativa ou pro tanto. Se eu julgo que algo é um palito de fósforo, então eu posso vir a julgar que ele irá acender se eu o riscar. No entanto, essa não é uma conclusão inevitável daquele juízo. Há uma série de condições lógica e naturalmente possíveis em que do fato de algo ser um palito de fósforo não se segue que ele vai acender se for riscado: isso não irá acontecer se ele estiver enxarcado, ou se ele estiver seco, mas for riscado no vácuo (ibidem, p. 169).

O exemplo paradigmático de inferência preservadora de compromisso é a dedução: é impossível alguém se comprometer com a premissa de um raciocínio dedutivo sem automaticamente se comprometer também com a sua conclusão. ${ }^{64}$ Já o exemplo paradigmático de inferência preservadora de habilitação é a indução empírica: se alguém se compromete com a premissa, então pode se comprometer com conclusão (ibidem, pp. 168-169). A probabilidade que se atribui à conclusão de uma inferência indutiva não é entendida como uma probabilidade matemática, mas como um indicativo de que a sua correção é ceteris paribus: na presença de determinados compromissos colaterais, a conclusão não se segue da premissa.

Cláusulas ceteris paribus devem ser entendidas aqui no contexto do materialismo inferencial; elas não são abreviações de conjunções ou disjunções que, caso sejam falsas, transformam o raciocínio indutivo em dedutivo. Cláusulas ceteris paribus genuínas são irredutíveis ao discurso puramente extensional, e não temos como conhecer a priori todas as situações com o potencial de bloquear a correção

\footnotetext{
${ }^{64}$ Evidentemente, não são só os raciocínios dedutivos lógico-formais que são preservadores de compromisso. Há também deduções "materiais", como por exemplo, o movimento de "Isto é vermelho" para "Isto não é (completamente) verde, amarelo...".
} 
da inferência que vai da premissa à conclusão.

O segundo ponto, de que transições linguagem-linguagem podem envolver um tipo de herança interpessoal e intra-conteúdo, significa que o fato de um sujeito possuir um compromisso pode obrigar, precluir ou habilitar outrem a assumir um compromisso (BRANDOM, 1994, p. 175). Se introduzíssemos essa mecânica no jogo de fichas padrão apresentado em 4.2.1, então as possibilidades dos jogadores de jogar apropriadamente as cores seriam muito mais limitadas. Todos os jogadores deveriam ter exatamente os mesmos compromissos e, uma vez que cada jogador só pode jogar uma ficha por rodada, o primeiro jogador na ordem seria o único a ter uma habilitação por default garantida. Esse compartilhamento de status deônticos pelos jogadores desempenha um papel essencial na explicação da objetividade (independência do juízo de Wright) das práticas normativas, conforme é argumentado em 4.6. ${ }^{65}$

O caso paradigmático de herança interpessoal intraconteúdo aqui é o do conhecimento por testemunho. Se eu estou em uma cidade em que eu nunca estive antes e pergunto a um habitante local onde fica a prefeitura, a sua alegação que eu espero como resposta - o compromisso doxástico que ela expressa - será utilizada como "premissa" para a minha assunção desse mesmo compromisso doxástico.

A inferência que vai da alegação do sujeito à minha crença é, como já se deve supor, uma inferência preservadora da habilitação. Um testemunho tem uma presunção relativa, por default, de verdade; consideramos o testemunho de outrem como sendo confiável caso não haja nenhuma indicação objetiva ou subjetiva em sentido contrário, e, novamente, não há uma descrição extensional exaustiva das situações em que a presunção é afastada.

O essencial aqui é que as alegações que os sujeitos de uma prática discursiva fazem no dia-dia tem necessariamente tanto a presunção de veracidade (isto é, o compromisso doxástico que a alegação expressa é efetivamente assumido pelo sujeito que a profere) quanto a presunção de verdade, enquanto correção objetiva. Se a veracidade e a verdade não fossem hegemônicas em nossas interações

\footnotetext{
65 A herança interpessoal e intraconteúdo não é o único modo de gerar compartilhamentos de compromissos entre os jogadores, e no caso das linguagenas naturais não é nem mesmo o principal. Cf. 4.3.2.
} 
comunicativas, então a própria prática discursiva estaria inviabilizada. A mentira e a falsidade são parasitárias da veracidade e da verdade.

\subsubsection{Transições linguagem-entrada}

Ao introduzirmos o jogo das fichas coloridas, dissemos que os jogadores possuem uma habilitação por default para jogar as cores, isto é, para jogar qualquer cor em relação a qual suas atuais pontuações deônticas não os precluam. Essa habilitação que os jogadores possuem não é, entretanto, exatamente como aquela que ocorre no jogo das linguagens naturais. Ao menos enquanto não houver uma ficha em seu próprio painel, qual cor cada jogador vai jogar é algo inteiramente ao seu próprio arbítrio. Isso faz com que possamos caracterizar as "posições iniciais" do jogo das fichas como sendo não inferenciais em um sentido absoluto que não encontra correspondência nas linguagens naturais. ${ }^{66}$

No jogo das linguagens naturais, nenhuma transição linguagem-entrada é arbitrária em absoluto; transições linguagem-entrada são movimentos inferenciais em um sentido amplo, de modo que elas devem envolver conceitos empíricos, e só são validamente realizadas nas circunstâncias perceptuais adequadas. Mas o jogo das fichas padrão apresentado em 4.2.1 não possui nada análogo a circunstâncias perceptuais, ou seja, não possui qualquer input não simbólico capaz de alterar os status deônticos dos jogadores.

Podemos vislumbrar uma variante desse jogo para que tenhamos um modelo mais acurado para os relatos e juízos observacionais das linguagens naturais. Imaginemos que no teto da sala haja uma fileira de lâmpadas coloridas, bem visível por todos, de modo que cada uma das lâmpadas pode ou não estar acesa.

Nessa versão do jogo, todas as cores jogadas ou correspondem às cores das lâmpadas que estão acesas ou são cores que são implicadas pelas cores das lâmpadas que estão acesas (por exemplo, afixar um círculo amarelo no seu painel em decorrência do fato de a lâmpada amarela estar acesa é como fazer um relato observacional; e cada jogador pode checar se a jogada do outro é válida ou não

\footnotetext{
${ }^{66}$ Se nós assumirmos que os jogadores do jogo das fichas possuem uma linguagem natural e aprenderam explicitamente esse jogo através das suas respectivas línguas naturais, então as posições iniciais do jogo são posições iniciais apenas relativamente ao próprio jogo; em sentido mais amplo, afixar um círculo colorido no painel é realizar uma transição linguagem-saída (de uma formulação verbal da regra do jogo para uma performance que não envolve o uso direto de conceitos). Para todos os efeitos, estamos deixando esse complicador de lado.
} 
simplesmente olhando para as lâmpadas no teto. O compartilhamento de status deônticos dos sujeitos agora é gerado pelo fato de os inputs não simbólicos e extrajogo serem também compartilhados.

A tradição inferencialista costumeiramente fala em relatos observacionais como consistindo em usos não inferenciais de enunciados. Comentando as posições de Sellars, Brandom afirma (1994, pp. 216-217):

Há instâncias particulares do acreditar ou estar comprometido que são não inferenciais no sentido de que sua aquisição não é a conclusão de um processo inferencial. (...) Inferência não precisa estar envolvida no processo que leva a uma ocorrência de "Isto é verde"; mas está ela envolvida na apreensão do tipo de autoridade que tais ocorrências produzidas não inferencialmente tem, e assim no entendimento de tais ocorrências, e assim em ser expressões potenciais de conhecimento.

Nesses casos, a noção de inferência utilizada pelos autores é não apenas uma noção restrita - em que inferências são relações apenas entre enunciados - mas também uma noção psicológica. Uma inferência - no seu sentido psicológico - envolve uma espécie de transição de um pensamento a outro, quer através de prolações verbais manifestas, como quando numa conversação, ou in foro interno, como quando estamos raciocinando em silêncio. Assim, um relato observacional é não inferencial no sentido de que um enunciado é proferido como uma resposta direta, irrefletida, às circunstâncias perceptuais nas quais o sujeito se encontra.

Expressões linguísticas cujo uso correto é estabelecido por meio da sua ocorrência em relatos observacionais expressam conceitos empíricos. Poderíamos com segurança estipular que alguns desses conceitos empíricos são fundamentais: sua total apreensão exige que o sujeito seja capaz de identificá-lo em resposta direta às situações perceptuais nas quais ele se encontra (a tradição empirista chamou os predicados que expressam tais conceitos de predicados observacionais). Além disso, todos os outros conceitos empíricos seriam definidos como sendo compostos por tais conceitos fundamentais. Baterias de conceitos de sabor e cor, e pares conceituais como frio-quente, agudo-grave, claro-escuro se expressam linguisticamente em predicados observacionais. ${ }^{67}$

Entretanto, o papel que os predicados observacionais (e os relatos observacionais a partir dos quais eles são definidos) desempenha numa teoria semântica inferencialista é bastante diferente do papel que eles desempenham nas teorias semânticas empiristas tradicionais, associadas ao representacionismo.

\footnotetext{
${ }^{67}$ Uma sugestão de abordagem sistemática para o tópico se encontra em Wright (2001, cap. 7)
} 
Sellars e Brandom não rejeitam a ideia, defendida pela tradição empirista, de que proposições envolvendo conceitos empíricos fundamentais tenham um status epistêmico mais básico que os demais conceitos - no sentido de que a verdade de tais proposições não é conhecida inferencialmente, no sentido estrito de inferência:

Se eu rejeito a estrutura do empirismo tradicional, não é porque eu queria dizer que o conhecimento empírico não tenha fundação. Existe certamente alguma razão na imagem do conhecimento humano como repousando sobre proposições - relatos de observação que não repousam em outras proposições da mesma forma em que outras proposições repousam nelas. (SELLARS, 2008, p. 89)

O que eles rejeitam categoricamente é a ideia - impregnada no verificacionismo, por exemplo - de que compreensão de um predicado observacional por um sujeito envolve tão somente a capacidade de responder confiável e diferenciadamente à experiência sensorial.

$\mathrm{O}$ que nos diferencia - enquanto seres sapientes - de animais infralinguísticos e artefatos capazes de relatar confiável e diferencialmente a presença de algo vermelho nas redondezas é que nós dominamos também as consequências de aplicação do predicado "vermelho" (BRANDOM, 1994, pp. 8889). Sabemos, ao contrário de um papagaio ou espectrofotômetro, que se algo é vermelho, então é colorido; que se algo é totalmente vermelho em um determinado momento, então não pode ter qualquer outra cor naquele mesmo momento; e que se algo é vermelho, ele continua tendo essa propriedade mesmo quando no escuro.

O papel atribuído tradicionalmente aos conceitos empíricos fundamentais e aos relatos observacionais na arquitetura do conhecimento é "mitológico", como diz Sellars, não porque eles não possuam um status justificacional mais básico, mas porque eles não podem ser apreendidos isoladamente - um a um. O holismo semântico do inferencialismo exige que, para que um sujeito seja considerado como um sujeito racional - capaz de ter crenças e proferir enunciados que almejem o status de conhecimento - tal sujeito deve ter apreendido muitos conceitos, e dominado o uso (dado em termos de circunstâncias e consequências de aplicação) de uma certa fração de expressões linguísticas que integram uma linguagem natural.

No uso não inferencial ou de relato de conceitos empíricos, somos considerados como possuindo uma habilitação por default para possuir compromissos que os envolvam. Estamos habilitados a dizer ou julgar, por exemplo, que o ambiente onde nós estamos está quente ou frio, sem que precisemos estar prontos a justificar nossa asserção ou crença para outrem mostrando um termômetro. Por ser uma habilitação pro tanto, ela obviamente pode vir a ser 
desafiada, mas o próprio ato de desafiá-la possui os seus critérios de adequação. É aceitável que alguém duvide da minha asserção de que está frio se meu interlocutor sabe que eu estou gripado naquele momento. Mas se meu interlocutor desafia a habilitação de toda e qualquer pessoa usando um conceito empírico em um relato, então ele simplesmente não compreende bem no que consiste a nossa prática discursiva. Atribuir habilitações por default para o uso de conceitos empíricos em relatos é uma condição de possibilidade da existência do próprio uso de conceitos empíricos. Só há prática, só há linguagem, porque os sujeitos são sensíveis a reconhecer quando estamos ou não efetivamente habilitados a um compromisso.

\subsubsection{Transições linguagem-saída: ações e intenções}

Transições linguagem-entrada e linguagem-linguagem ocorrem na forma de juízos ou alegações, de modo que elas paradigmaticamente expressam crenças (compromissos doxásticos) do sujeito que realiza o proferimento. Brandom, seguindo Kant, considera que sujeitos capazes de dar e pedir razões para alegações e crenças possuem racionalidade teórica. Mas ele também lembra que Kant concebe um segundo tipo de racionalidade, que ele chama de racionalidade prática, e que pode ser definida como o jogo de dar e pedir razões para ações (Brandom, 1994, p. 230). E tanto a racionalidade teórica como prática recebem no final das contas uma abordagem unificada na obra kantiana, a qual Brandom se coloca como dando prosseguimento:

(...) juízos e ações são, sobretudo, coisas pelas quais somos responsáveis. Kant entende conceitos como tendo a forma de regras, ou seja, especifica como algo deveria (de acordo com a regra) ser feito. O entendimento, a faculdade conceitual, é a faculdade de apreender regras, de apreciar a distinção entre a aplicação correta e incorreta que elas determinam. Juízos e ações são atos que alguém pode tornar ou tomar como verdadeiros e para os quais dirige-se a demanda por razões. O que é distintivo sobre eles é a maneira como são regidos por regras. (2001, p. 183)

Em uma teoria do significado inferencialista, são consideradas ações todas as performances (ou conjunto de performances) de sujeitos da prática para as quais é concebível postular e pedir razões. Alegações são justificadas por outras alegações que expressam crenças ou compromissos doxásticos; ações, por sua vez, são justificadas por alegações que expressam intenções ou compromissos práticos (idem, 1994, p. 244). A minha performance de virar o interruptor do meu quarto é considerada uma ação na medida em que está inferencialmente articulada com a minha intenção de acender a luz do meu quarto. 
Para que uma performance de um sujeito conte como sendo uma ação, não é necessário que ele tenha formado a sua intenção - assumido um compromisso prático - em um momento anterior à realização da performance: o meu virar o interruptor do meu quarto é uma ação mesmo que eu tenha constituído a intenção de acender a luz em concomitância com a minha própria performance. Isto é o que os teóricos da ação chamam de intenção em ação (ibidem, p.256). Por outro lado, é também obviamente possível que uma intenção prévia não se desdobre em ação, seja porque o sujeito deixa de possuir tal intenção (seria o equivalente ao "desmentido" no âmbito dos compromissos doxásticos) ou porque, nos momentos subsequentes, a realização da ação não vem a ser materialmente viável (por exemplo, eu pretendia acender a luz do quarto quando entrasse nele, mas antes descubro que houve um blecaute, e que não há energia elétrica no momento).

Também podemos considerar uma performance de um sujeito como constituindo uma ação mesmo que ele não tenha realizado tal performance intencionalmente, se ele pode ser considerado como tendo uma razão para realizar tal performance. Isso ocorre quando nós atribuímos um compromisso prático que ele mesmo não reconhece possuir; diríamos, nesses casos, que o sujeito age com razão, mas não por razão (BRANDOM, 1994, p. 244). No limite, tratamos crianças de colo e animais infralinguísticos como realizando ações se nossa atitude intencional, de atribuir a eles compromissos (tanto doxásticos quanto práticos) nos auxilia a prever e explicar seus comportamentos ${ }^{68}$. Assim, por exemplo, frequentemente nos referimos ao comportamento dos esquilos de depositar nozes em locais de difícil visualização e acesso como esconder nozes para (comer) no inverno.

A situação inversa é, no entanto, mais comum: considerarmos uma performance como sendo uma ação pelo fato de o sujeito possuir um compromisso prático para o qual não o tomamos como estando habilitado, ou mesmo por sua performance decorrer de um impulso, sendo incompatível com compromissos doxásticos e práticos que estejamos atribuindo ao sujeito, ou até que sejam reconhecidas pelo próprio sujeito. Se alguém, em um andar alto de um edifício em chamas, salta pela janela em desespero, consideramos tal performance como uma ação - justificada pelo compromisso prático de preservar a própria vida e

\footnotetext{
${ }^{68}$ Discutimos a relação entre atribuição de estados intencionais a seres "infralinguísticos" - animais
} e crianças de colo - e a explicação dos seus comportamentos inteligentes em 5.1.1. 
integridade física postas em xeque pelo fogo - embora não a reconheçamos como sendo racional, uma vez que ela do mesmo modo não contribui para a realização desse compromisso prático. O ponto principal é que, uma vez que consideramos certo organismo como um sujeito racional, então interpretamos quaisquer performances que possam estar inferencialmente relacionadas com compromissos atribuídos a ele ou reconhecidos por ele.

No caso de transições linguagem-linguagem, os "pontos de partida" inferenciais não possuem necessariamente nenhum traço lógico distintivo, e, no caso das transições linguagem-entrada, os "pontos de partida" inferenciais são circunstâncias observacionais, e consequentemente, não linguísticos. Mas no caso das transições linguagem-saída, os compromissos práticos - os "pontos de partida" inferenciais para a ação - efetivamente devem possuir algum traço lógico característico que nos permita identificá-los enquanto tais, contrastando com os compromissos doxásticos. Em outras palavras, isso significa que nós devemos perguntar pela forma lógica dos compromissos práticos; que operador lógico é a marca registrada, por assim dizer, de uma alegação usada por um sujeito para expressar sua intenção?

De acordo com Brandom, o operador que desempenha esse papel é aquilo que em inglês é expresso por shall e should, e que nós traduzimos aqui por devo e deveria $^{69}$. A atribuição de um compromisso prático por um sujeito $s^{\prime}$ a um sujeito $s$ ocorreria paradigmaticamente através do proferimento de um enunciado da forma "s deveria (should) $p$ "70, onde $p$ é o compromisso doxástico que qualquer sujeito estará habilitado (nas circunstâncias adequadas) a possuir a partir do momento em que a ação se concretiza (ibidem, p. 269).

Tal como no âmbito da racionalidade teórica, o expressivismo lógico vem acompanhado de um materialismo inferencial também no âmbito da racionalidade prática (ibidem, pp. 245-246). Brandom considera raciocínios práticos como (1) (TMG se mantém seco ao sair em um dia chuvoso) $\leftrightarrow$ (TMG abre o guardachuva)

\footnotetext{
${ }^{69} \mathrm{O}$ vocábulo "shall" em inglês possui uma carga normativa, essencial na explicação de Brandom, que não é preservada se o traduzirmos por "irei".

${ }^{70}$ Obviamente, s e s' podem coincidir, de modo que seu proferimento teria a forma "Eu devo (shall) p"; um sujeito reconhecer um compromisso, proferindo uma alegação da forma "Eu devo p" nada mais é do que ele explicitamente atribuí-lo a si próprio.
} 
(2) TMG deve/deveria (should) abrir o guarda-chuva ao sair em um dia chuvoso como sendo perfeitamente bons enquanto tais. Não haveria nenhuma premissa entimemática (vamos supor, "TMG quer / deseja se manter seco ao sair em um dia chuvoso") esperando para ser explicitada para que o argumento fosse mostrado como formalmente válido.

Pelo contrário, Brandom sustenta que é o discurso volitivo - querer, desejar, preferir - que é definido em função do operador shall/should. O enunciado "TMG quer/deseja se manter seco ao sair em um dia chuvoso", que, de acordo com um formalista inferencial, seria interpretado como uma premissa oculta, para Brandom serviria - através do operador querer / desejar - como uma classificação e explicitação de um tipo de compromisso prático (ibidem, p. 267). O operador querer / desejar serve para indicar o tipo de inferência onde não opera a herança interpessoal-intraconteúdo entre sujeitos. Quando alguém me atribui o desejo de me manter seco, o que se está fazendo é me atribuir habilitação para adquirir o compromisso com (2) em função de eu ter compromisso com (1), ao mesmo tempo em que não endossa ele mesmo um compromisso de (1) (um análogo) a (2), nem atribui automaticamente habilitação a (2) a qualquer outro sujeito que esteja comprometido com (1). ${ }^{71}$

Brandom destaca ainda a existência de uma certa simetria entre transições linguagem-entrada (relatos observacionais) e linguagem-saída (ações). O domínio por um sujeito de conceitos com conteúdo empírico-observacional envolve, como foi colocado, a posse por esse sujeito de disposições responsivas diferenciais (DRD's) confiáveis. Por exemplo, o sujeito diz "Isto é redondo" apenas de objetos redondos que ele percebe em suas adjacências no momento do proferimento. Isso significa que, apesar de a relação entre as circunstâncias perceptuais do sujeito e a

\footnotetext{
${ }^{71} \mathrm{O}$ tipo de inferência prática que é codificada pelo operador querer/desejar é chamado por Brandom de prudencial. Ele postula outros dois tipos de inferência prática - institucional e incondicional, igualmente determinados pela incidência e alcance do mecanismo de herança interpessoal e intraconteúdo. Inferências práticas institucionais são herdadas por todos os sujeitos que satisfazem uma determinada condição. Por exemplo, se João é um funcionário de um banco, e se eu acredito que todos os funcionários de banco devem usar gravatas, então eu atribuo a João, mas não a mim, o compromisso prático de usar gravata. Já as inferências práticas incondicionais funcionam exatamente como inferências teóricas: elas se aplicam universalmente. Por exemplo, se eu atribuo a João o compromisso prático de não mentir sem motivo, então, pela natureza moral (incondicional) desse compromisso, eu automaticamente o endosso.
} 
aquisição de um compromisso ser normativa (posto que inferencial no sentido mais amplo), há algum tipo de relação disposicional-causal entre a presença de objetos redondos e a prolação de um relato observacional (ou o entretenimento de um juízo observacional). De um modo resumido, há uma relação causal-disposicional entre um fato - digamos $\mathrm{Fa}$ - e o proferimento pelo sujeito de "Fa" (ou o entretenimento do pensamento de que $\mathrm{Fa}$ ), assim como há uma relação causal-disposicional entre o fato de que $\mathrm{Fa}$ e o proferimento por um papagaio bem treinado de "Fa".

Do mesmo modo, a capacidade dos sujeitos de realizarem transições linguagem-saída - codificada pelo operador shall/should - envolve, embora não se resuma à - posse pelos sujeitos de habilidades responsivas diferenciais (HRD's) confiáveis (BRANDOM, 1994, p. 234). Se eu possuo o compromisso prático de me manter seco ao sair em um dia chuvoso, então eu tenho de confiável e diferencialmente responder a certos inputs perceptuais - por exemplo, a chuva caindo em um lugar onde eu não esteja coberto - com os outputs comportamentais que constituem a ação - no caso, abrir o guarda-chuva e me manter embaixo dele até que não esteja mais chovendo, ou até que eu esteja em um local protegido da chuva.

Há, entretanto, uma prioridade explicativa da racionalidade teórica sobre a racionalidade prática; em primeiro lugar, o sucesso de ações só pode ser avaliado por meio de alegações. Em segundo lugar, e, especialmente, compromissos práticos são definidos em termos de compromissos doxásticos e estão necessariamente articulados inferencialmente com eles (um compromisso prático sempre tem compromisso doxástico como premissa). Compromissos doxásticos, por outro lado, podem subsistir por si só:

Um compromisso prático é um compromisso de agir. O conteúdo de um tal compromisso prático é fazer verdadeira uma alegação. Estes compromissos e seus conteúdos são inteligíveis apenas em um contexto que inclua também considerar verdadeiras alegações. Pois é em termos de tais tomar-como-verdadeiro assercionais que o sucesso das ações, a satisfação de compromissos práticos, deve ser entendida. (...) não se pode dar razões a menos que se possa reconhecer compromissos doxásticos ao fazer alegações. (BRANDOM, 1994, p. 233)

Por último, mas não menos importante, não é necessário que compromissos práticos sejam expressos em um tipo particular de ato de fala. Compromissos práticos são totalmente exprimíveis em termos de alegações envolvendo vocabulário normativo: "Você deve (shall/should) fazer a lição de casa" tem via de regra o mesmo significado que "Faça o dever de casa!”. Assim, um comando (uma 
sentença no modo imperativo) ou uma solicitação podem ser tomados como uma codificação "pragmática" de certos usos em terceira pessoa de shall/should - ou seja, introduzimos uma força discursiva para atribuir explicitamente um compromisso prático a alguém.

\subsection{Operadores lógicos, predicados e termos singulares: da lógica proposicional à lógica de predicados}

Até agora, estivemos tratando oficialmente de compromissos como coisas meio monolíticas, como se a expressão material deles - alegações / enunciados constituíssem tipos monolíticos: símbolos sintaticamente não estruturados e inteiramente diferentes entre si. A analogia de enunciados com fichas coloridas ajuda a vermos as coisas dessa forma. Entretanto, linguagens naturais (bem como a lógica que subjaz a elas) são composicionais, sintaticamente articuladas; elas possuem um número virtualmente infinito de enunciados gerados a partir de um conjunto finito de símbolos e regras sintáticas que regem a (boa) formação desses símbolos

Por outro lado, nas seções anteriores, falamos de conceitos e predicados (e pressupusemos obviamente termos singulares e particulares) na teoria inferencialista sem explicarmos essas categorias semânticas a partir dos elementos fundantes dessa teoria. Nesta seção, a composicionalidade recursiva da linguagem, bem como as categorias semânticas fundamentais dos enunciados simples predicado e termo singular - são oficialmente integradas ao edifício teórico inferencialista.

\subsubsection{Substituição: expressões substituídas-por, substituídas-em e estruturas substitucionais}

De acordo com Brandom, a chave para a explicação da composicionalidade da linguagem é a ideia de substituição inferencial, associada ao trabalho do jovem Frege. Quando falamos sobre a doutrina do expressivismo lógico em 4.1, essa era a ideia por trás do método de "recortar" o vocabulário de uma linguagem em termos de um vocabulário privilegiado $(K)$ e outro "remanescente" (não-K) e então definirmos certas inferências como K-formalmente boas - isto é, inferências entre tipos linguísticos cuja bondade depende apenas da análise das adequações inferenciais do vocabulário K envolvido em questão. Como foi apontado ali, as 
expressões “não", “se.. então...", "e” etc. se tornam oficialmente operadores lógicos exatamente quando especificamos seus papeis inferenciais através da arregimentação do léxico de nossa estrutura em vocabulário $\mathrm{K}$ e não-K. ${ }^{72}$

A introdução de expressões subsentenciais propriamente ditas - predicados e termos singulares - demanda que utilizemos o "bisturi" substitucional para definirmos primeiro o que significa o type de uma expressão subsentencial pertencer a uma mesma categoria sintática. De acordo com Brandom (2001, p. 130):

Duas expressões subsentenciais pertencem a mesma categoria gramatical ou sintática apenas no caso de nenhuma sentença bem formada (expressão que pode ser usada para realizar um dos tipos fundamentais de atos de fala) na qual uma expressão ocorre poder ser transformada em algo que não é uma sentença meramente pela substituição dessa expressão pela outra.

Por exemplo, em "Maria é mais alta que Mário", se trocarmos "Maria" por “Ana", ou, se trocarmos"é mais alta que" por "é mais baixa que", as estruturantes resultantes da substituição são também sentenças bem formadas. Mas o mesmo obviamente não acontece se trocarmos "Maria" por "é mais baixa que" e "é mais alta que" por "Ana". Isto por que os pares de expressões "Maria" e "Ana" e "é mais alta que" e "é mais baixa que" pertencem as mesmas categorias sintáticas, mas os pares eles próprios integram diferentes categorias (de termo singular e predicado binário, respectivamente)..$^{73}$

Por sua vez, duas expressões subsentenciais de mesma categoria possuem o mesmo conteúdo semântico se a substituição de uma pela outra em um enunciado não altera os seus atributos inferenciais (ibidem, p. 130). Retomando o exemplo acima, a substituição de "Maria" por "Ana” em "Maria é mais alta que Mário" (cujo produto é "Ana é mais alta que Mário") altera os seus atributos inferenciais. De "Maria é mais alta que Mário" segue-se "Mario é mais baixo que Maria"; mas, de “Ana é mais alta que Mário" não se segue "Mário é mais baixo que Maria”. Assim,

\footnotetext{
${ }^{72}$ Podemos considerar, a título de esclarecimento, que esse nível de composicionalidade expresso pela lógica proposicional é o mais básico ou primitivo da linguagem: antes de haver termos singulares, predicados e mesmo outros operadores lógicos, uma linguagem inferencialmente articulada (se é que podemos chamar isso de linguagem) possui apenas tipos proposicionais atômicos e os operadores verofuncionais derivados da aplicação do expediente acima.

${ }^{73}$ Por essa definição, predicado é uma categoria sintática com um grau de abstração maior do que a de termo singular. Com efeito, a definição de uma categoria sintática nos termos propostos por Brandom envolve não apenas o modo como suas instâncias contribuem para as propriedades inferenciais dos enunciados nos quais tais instâncias ocorrem, mas também aquilo que os lógicos chamam de aridade. A mesma observação que se aplica a predicados também se aplica aos operadores da lógica proposicional: embora "não" e "se ... então" sejam tratados como integrando uma mesma categoria sintática, preservamos a "sentencidade" de " $p \rightarrow q$ " se substituirmos " $\rightarrow$ " por “↔”, “\&” ou “ou”, mas não por “ ".
} 
"Maria" e "Ana" são expressões subsentenciais de mesma categoria, mas discerníveis entre si. ${ }^{74}$

Brandom destaca que há três tipos de papeis substitucionais que uma expressão pode desempenhar: substituído-por, substituído-em e estrutura substitucional, onde os papeis de substituído-por e substituído-em são primários e o papel de estrutura substitucional é derivado dos outros dois (2001, p. 131).

As expressões que cumprem o papel de substituídas-por são aquelas que, em um procedimento de substituição, são substituídas ou são substitutas. Já as expressões substituídas-em são aquelas que permanecem constantes durante o processo de substituição; e as estruturas substitucionais são expressões substituídas em abstraídas de uma expressão substituída-por (BRANDOM, 2001, pp.130-131). Assim, quando operamos a transformação substitucional de

Maria é mais alta que Mário

para

Ana é mais alta que Mário

"Maria" e "Ana" são expressões substituídas-por, "é mais alta que Mário" é uma expressão substituída-em em ambos enunciados, e “( ) é mais alta que Mário" é a estrutura substitucional derivada da substituição.

A categoria de termo singular pode ser então definida, a partir de uma perspectiva inferencialista, como sendo aquela categoria composta por todas as expressões (tipos) que desempenham um papel substituicional de substituído-por. A característica inferencial distintiva de um termo singular é o fato de eles ser, necessariamente, envolvido em relações inferenciais de natureza simétrica. Em outras palavras, podemos definir termo singular como sendo a categoria sintática que permite o emprego do próprio procedimento substitucional em uma linguagem. Se não for possível discernir entre categorias subsentenciais através de substituições (fregeanas) em uma linguagem, então isso significa que ela simplesmente não é sintaticamente articulada. Termos singulares, de acordo com Brandom, constituem

\footnotetext{
${ }^{74}$ Notemos que quando Sellars, Brandom e Peregrin falam em expressões possuírem o mesmo conteúdo semântico (o jovem Frege diria "conteúdo conceitual”), não isso implica necessariamente que elas sejam sinônimas. "Brasília" e "a capital do Brasil" seriam consideradas como tendo o mesmo conteúdo semântico, mas certamente não são expressões sinônonimas; a noção de sinonímia só tem lugar quando a linguagem em questão for expressivamente mais rica do que a estrutura que temos até o momento.
} 
classes de equivalência de termos intersubstituíveis (2001. p. 138).

Predicados, por sua vez, são a categoria sintática que inclui expressões substituídas-em em sentenças atômicas, por meio das quais derivamos estruturas substitucionais. Um predicado, ao contrário de um termo singular, está envolvido em relações inferenciais que não são necessariamente simétricas. Predicados poderiam ser definidos, então, como a categoria sintática das expressões substenciais que são responsáveis pelo fato de haver assimetrias inferenciais entre enunciados; dito de outro, predicados são o tipo de categoria que faz com que um antecedente de um condicional seja - ao menos em princípio - mais fraco que o consequente, onde força é definida em termos da quantidade de enunciados que um determinado enunciado implica (BRANDOM, 2001, pp.147). Por exemplo, o enunciado "Thera é um cachorro" é inferencialmente mais forte do que o enunciado "Thera é um mamífero" em função do predicado "cachorro" ser inferencialmente mais forte que o predicado "mamífero": tudo que se segue de um enunciado onde ocorre o predicado “(é um) mamífero" se segue de "(é um) cachorro", mas não o contrário. O predicado "(é um) cachorro" implica outros predicados que não necessariamente se segue de "(é um) mamífero": por exemplo, “(é um) animal tipicamente doméstico", “(é um) quadrúpede”, "tem um olfato muito apurado" etc.

Mas não podemos substituir um predicado por outro em um enunciado sem alterar os atributos inferenciais desse enunciado? Não fazemos isso quando, dado o enunciado "Pedro é solteiro", trocamos "solteiro" por "não-casado"? Brandom obviamente reconhece essa possiblidade, mas aponta que esse tipo de substituição é derivado: uma vez que temos uma estrutura inferencial remanescente de um procedimento de substituição primário - no caso “( ) é solteiro" - podemos substituir um predicado por outro; e, para algumas substituições de um predicado em uma estrutura por outro, os atributos inferenciais da estrutura são efetivamente preservados. Brandom chama substituições derivadas ou secundárias de troca (replacing) (2001, p. 132). Todo o ponto é que, quando recortamos uma expressão subsentencial por outra de forma que elas desempenhem papel de substituídas-por, sabemos de antemão, por definição (isto é o que faz elas serem substituídas-por) que as duas expressões são inferencialmente equivalentes. Para expressões substituídas-em, não há nenhuma garantida de que haja naquela linguagem outra expressão infernecialmente equivalente a ela, e isso é o que faz, por definição, que ela tenha o papel inferencial substituicional de substituída-em. 


\subsubsection{Deduções expressivas}

Um detalhe importante é que essa forma lógica de enunciados simples ou atômicos, constituída por termo singular e predicado em uma linguagem inferencialmente articulada não é algo estabelecido arbitrariamente. Pelo contrário, a ideia é que, uma vez que essa linguagem possui os operadores proposicionais verofuncionais que codificam as relações inferenciais, então se segue necessariamente que os papeis inferenciais das expressões subsentenciais são classificados como sendo de termo singular ou predicado. Brandom chama esse argumento de dedução expressiva (2001, p. 153).

O raciocínio é relativamente simples. O operador condicional expressa logicamente a relação inferencial de implicação - o que em termos pragmáticos equivale a herança interconteúdo: se um sujeito é considerado como estando comprometido com "p", então deve por esse fato ser também considerado como estando comprometido com, digamos, “q”. Já o operador da negação expressa logicamente a relação inferencial de incompatibilidade entre os compromissos expressos pelos tipos sentenciais: se o compromisso com " $r$ " preclui o sujeito de assumir um compromisso, com "p", então "r" implica "não-p", onde “não-p" é a sentença que é minimamente incompatível com “p” (BRANDOM, 2001, p. 147).

Uma vez que temos esses dois operadores, temos necessariamente o bicondicional, pois o bicondicional é definido em termos da conjunção de dois condicionais, e a conjunção, por sua vez, é identificada como sendo o operador equivalente à negação de um condicional cujo consequente envolve uma negação. Uma vez que temos oficialmente o bicondicional em nossa linguagem, temos como expressar a identidade de potencial inferencial entre dois ou mais (tipos de) enunciados. ${ }^{75} \mathrm{E}$, uma vez que podemos fazer isso, podemos definir os papeis inferenciais de expressões substituídas-por e substituídas-em em função do modo como elas contribuem para a identidade de potencial inferencial daqueles dois (ou mais enunciados).

Considerando que uma linguagem possui oficialmente duas categorias

\footnotetext{
75 Há outro caminho, mais simples, para a introdução do bicondicional. Se pensarmos que a linguagem em questão é aberta, no sentido de que os sujeitos podem introduzir novos enunciados definidos a partir de enunciados de um "estoque básico", então é necessário um operador lógico para exprimir essa identidade. Esse operador é justamente o bicondicional.
} 
básicas de expressões subsentenciais, já se pode também derivar os quantificadores da lógica dos predicados. Do ponto de vista lógico, termos podem ser gerados ao tratarmos predicados de um modo "especial", ou seja, como um vocabulário-K. ${ }^{76}$

O conjunto das deduções expressivas para o discurso semântico -isto é, de todo e qualquer vocabulário intencional, o que envolve não apenas os operadores lógicos da lógica clássica, mas também operadores modais doxásticos, epistêmicos, etc - visa mostrar o seguinte: para que uma prática social exista ela tem de possuir, necessariamente, um caráter social (intersubjetivo) e objetivo. Práticas não discursivas - isto é - práticas cujos tipos e tokens não possuam função representacional - pressupõem a existência de práticas discursivas, dado que é o poder expressivo de uma prática discursiva que possibilita a constituição de práticas não discursivas.

\subsection{Vocabulário intencional: da semântica inferencial à representação}

Para atestarmos que as duas categorias básicas da semântica inferencial correspondem realmente ao que nós chamamos de termo singular e predicado, precisamos mostrar que elas de fato desempenham as funções que a tradição concebeu como caracterizadoras de tais categorias. Um termo singular se refere a um objeto - individualiza e identifica um particular entre muitos, possivelmente infinitos outros particulares. Já um predicado classifica objetos, dividindo o "estoque" de particulares a partir do qual o mundo é feito em conjuntos de particulares.

Agora, mostrar que as duas categorias básicas do inferencialismo são mesmo termo singular e predicado é mostrar exatamente como ir da inferência à representação. No nível de uma teoria semântica, isso consiste em explicar como o vocabulário intencional próprio das linguagens naturais é obtido, de modo derivado, do vocabulário técnico inferencial que estamos utilizando. Brandom considera que, nas linguagens naturais, as expressões chave da intencionalidade são as locuções $d e$ (do / de o), sobre (a respeito de/do) quando tratamos proposições como sendo

\footnotetext{
${ }^{76}$ A definição fregeana de um quantidicador como um predicado de $2^{\mathrm{a}}$ ordem nos dá a pista de como obtê-los. "Todo A é B" expressa o compromisso que um sujeito tem de predicar "B" de cada um dos termos singulares os quais ele venha a predicar "A". O símbolo de identidade ("=)), por outro lado, antes de expressar que dois termos singulares se referem a um mesmo objeto, expressa que dois ou mais termos singulares são regidos por um mesmo compromisso substituicional, material simples, ou conjunto de compromissos substitucionais materiais simples.
} 
decomponíveis (2001, p. 169); e verdade (é verdadeiro que) quando as tratamos como indecomponíveis (1994, p. 278).

A dedução expressiva dessas expressões consistiria numa espécie de argumento da linguagem privada no nível de uma teoria semântica - isto é, uma demonstração de que se uma linguagem oferece os recursos para que derivemos tais expressões, então ela é necessariamente objetiva e intersubjetiva. O argumento da linguagem privada inferencialista ao nível da teoria fundacional do significado, por sua vez, é apresentado no capítulo 5 ao falarmos em maior profundidade a respeito da objetividade como característica necessária da normatividade.

As expressões referenciais e veritativas que marcam a função representacional da linguagem são, entretanto, logicamente posteriores ao vocabulário que explicita as atribuições de compromisso a um sujeito por parte de outros sujeitos. Esse vocabulário deve corresponder, no final das contas, ao vocabulário doxástico: a rota que leva de adequações inferenciais envolvendo compromissos a adequações referenciais envolvendo expressões linguísticas e coisas no mundo passa antes pela dimensão da intersubjetividade de uma prática discursiva.

Tomando o jogo das fichas como ilustração, vemos que dentro de uma abordagem inferencialista, atitudes proposicionais não são interpretadas como constituindo uma relação entre um sujeito e um objeto - físico ou fenomenológico - do mundo natural; muito menos elas são interpretadas como uma relação entre um sujeito e um objeto abstrato cuja subsistência é inteiramente independente das nossas mentes. Por outro lado, o inferencialismo é realmente uma forma de intensionalismo e assim, rejeita as explicações redutivas do naturalismo de estirpe extensionalista.

Um sujeito possuir um compromisso doxástico (crença) é uma questão desse sujeito ser corretamente reconhecido por outros como possuindo aquele compromisso. Nas linguagens naturais, uma atribuição de crença parece ter a forma lógica de um predicado diádico comum - $\mathrm{aRb}$ - usado para descrever fatos corriqueiros. Falamos de crenças nos moldes de objetos físicos ordinários, como se um sujeito acreditar em algo fosse mais ou menos análogo a um copo estar sobre a mesa. O caráter fundamentalmente pragmático de uma atribuição de crença é saliente, entretanto, quando pensamos no jogo das fichas coloridas: uma atribuição 
de compromisso feita por A a B é indicada pela afixação por A de uma ficha retangular na tábua para $\mathrm{B}$.

\subsubsection{Atribuições de dicto e de re}

Como vimos na seção 2.1.1., enunciados que envolvem atribuições de atitudes proposicionais são marcados, em termos de forma gramatical, pela subordinação após o verbo que expressa a atitude:

(1) Hamurábi acreditava que a estrela da manhã é a estrela da tarde.

Intensionalistas costumam interpretar tais enunciados como possuindo a forma lógica $\mathrm{aRb}$ - com um sujeito se relacionando a uma proposição por meio da própria atitude proposicional que ele realiza. ${ }^{77}$ Instâncias para esquema de enunciados " $s$ crê que $p$ " são verdadeiras na medida em que o sujeito s alegaria "É o caso que $p$ " se perguntássemos a ele se $p$ ou não- $p$ e sua resposta fosse sincera.

No entanto, há pelo menos algumas atribuições de atitudes proposicionais que destoam da interpretação usual aRb dada a elas pelos teóricos intensionalistas, ainda que elas se manifestem através de enunciados com a mesma forma gramatical de (1). Por exemplo, o enunciado

(2) Hamurabi acreditava que o planeta Vênus era mais brilhante que a Lua ao anoitecer

é falso se o interpretamos como possuindo a forma lógica $\mathrm{aRb}$, uma vez que o líder babilônio pensava se tratar de uma estrela (a "estrela da tarde") e nem sequer possuía o conceito de planeta. No entanto, há um sentido em que (2) pode ser verdadeiro: o sentido de que Hamurábi julgava de Vênus, que ele brilhava mais que a Lua ao anoitecer.

Não é difícil imaginar um contexto no qual (2) fosse proferido com esse segundo sentido: suponhamos um historiador dos dias atuais querendo chamar nossa atenção para o fato de que Vênus é visível a olho nu e que de fato era

\footnotetext{
77 Por motivos de simplicidade notacional, a proposição aqui, enquanto objeto de atitude proposicional pode ser tomada como um objeto indecomponível, embora ela possa ser parafraseada em um enunciado isolado (freestanding) que exiba sua estrutura sintática de termo singular e predicado.
} 
observado pelos povos antigos. O sentido em que a atribuição de atitude proposicional por meio de (2) é falsa (e que talvez possamos identificar com o seu significado literal) é chamado na literatura filosófica de de dicto. Já uma atribuição por meio de (2) que resulte em (2) ser verdadeiro é chamada de de re.

Para evitar ambiguidades, as atribuições de re aparecem na literatura filosófica sobre o tema de modo arregimentado e contendo uma expressão referencial. Assim, se o enunciado (2) é utilizado no sentido de re, ele é parafraseado em termos de

(2') A respeito do planeta Vênus, Hamurábi acreditava que era mais brilhante que a Lua ao anoitecer.

enquanto a forma gramatical de (2) é utilizada como cânone para atribuições de dicto.

Agora, Brandom argumenta que atribuições de atitudes de re são analisáveis em termos de atribuições de dicto. Sua proposta é de explicar a diferença entre os dois tipos de atribuição utilizando elementos já apresentados de sua teoria. Pela perspectiva da pragmática normativa de Brandom, atribuir uma crença de dicto é atribuir um compromisso em relação ao qual o sujeito atribuído estaria disposto a reconhecer como o possuindo (2001, p. 176). Em termos do jogo das fichas, isso equivale exatamente à congruência entre, digamos, um círculo amarelo no painel de A e um retângulo amarelo na tábua que B usa para registrar a pontuação de A.

$\mathrm{Na}$ especificação de re, entretanto, nem todo o conteúdo intencional que costumeiramente aparece depois da cláusula "que" está sendo atribuído ao sujeito da atitude. Uma parte é atribuída ao sujeito, mas não necessariamente endossada pelo atribuidor; outra é endossada pelo atribuidor, mas não necessariamente pelo sujeito a quem a atitude é atribuída:

Minha sugestão é que a função expressiva de atribuições de re de atitudes proposicionais é tornar explícitos quais aspectos do que é dito expressam compromissos sendo atribuídos e quais expressam compromissos sendo assumidos. A parte da especificação de conteúdo que aparece dentro da cláusula "que" de dicto é limitada ao que, de acordo com o atribuidor, alguém a quem o compromisso é atribuído reconheceria (ou, num sentido forte, deveria [reconhecer]) como uma expressão daquilo com o que este indivíduo está comprometido. A parte da especificação do conteúdo que aparece no escopo do "de" de $r e$ inclui o que, de acordo com o atribuidor do compromisso (mas, não necessariamente de acordo com alguém a quem ele é atribuído), é reconhecido como uma expressão daquilo com que o objeto da atribuição (Isso é o que o objeto deveria, de acordo com o 
atribuidor, reconhecer, num sentido muito mais fraco de "dever"). Então, a marcação de porções da especificação de conteúdo de uma atribuição de atitude proposicional em partes de dicto e de re torna explícita a distinção deôntica essencial no registro de pontos da perspectiva social entre compromissos atribuídos e assumidos. (BRANDOM, 2001, p.177)

Assim, se eu profiro um token de (2'), o que eu estou fazendo é assumir um compromisso com uma certa caracterização do objeto da crença de Hamurábi, sem atribuí-lo a ele. $\mathrm{O}$ compromisso que eu atribuo ao babilônio envolve esse mesmo objeto, mas sob uma caracterização diferente (ser o corpo celeste mais brilhante ao anoitecer), que, por acaso, eu também endosso. A forma lógica geral de uma atribuição de crença de re a um sujeito $s$ em termos de uma atribuição padrão de crença (de dicto) pode ser apresentada como

$$
(s \text { acredita de re que } \mathrm{Fa}) \leftrightarrow((s \text { acredita que } \mathrm{Fb}) \&(\mathrm{a}=\mathrm{b}))
$$

onde "F" é um predicado qualquer e "a" e "b" são termos singulares regidos pelos mesmos compromissos materiais substitucionais simples, ou seja., "a" e "b" são intercambiáveis em qualquer enunciado simples ou cujos operadores envolvidos não sejam outros além daqueles da lógica clássica.

Através do vocabulário referencial-semântico ("ser sobre", "de", "do") utilizado nas descrições de re, podemos manejar compromissos de outros sujeitos combinados com os nossos próprios compromissos. Podemos então extrair como consequência compromissos que esses sujeitos assumiriam se eles tivessem os nossos compromissos. A especificação de re de uma crença expressa aquilo que nós esperaríamos que o sujeito reconhecesse como verdadeiro se ele possuísse outras crenças colaterais que nós reconhecemos ter. Se Hamurábi tivesse o conhecimento de astronomia que nós temos, e se ele tivesse o conceito de planeta Vênus (isto é, se ele utilizasse uma expressão com aproximadamente o mesmo papel inferencial que o nosso termo singular "Vênus") então ele acreditaria que Vênus brilha mais do que a Lua ao anoitecer.

$\mathrm{O}$ que nos permite fazer descrições de re de atitudes proposicionais de outros sujeitos é o fato de que nós e o sujeito cuja atitude é atribuída compartilhamos pelo menos alguns compromissos substitucionais envolvendo o termo singular do enunciado em questão. Embora o uso expressão "estrela da tarde" por Hamurábi não tenha sido regido pelos mesmos compromissos substitucionais que regem o nosso uso de "estrela da tarde", ao menos alguns deles são 
compartilhados. Especificamente, nesse caso, associamos ao termo singular "estrela da tarde" um compromisso substitucional que Hamurabi também associava ao termo, o que permite passar de "estrela da manhã" para "corpo celeste mais brilhante ao anoitecer" em um enunciado simples. O operador de crença de re permite tratar a proposição que venha cair sob seu escopo como decomponível, de tal forma que os seus termos componentes possam ser tratados como se eles estivessem ocorrendo em enunciados simples.

A conclusão que podemos extrair então é que é esse grau mínimo de consenso a respeito dos compromissos substitucionais que regem o uso de termos singulares (e também de predicados) que torna possível tanto a referência objetiva às coisas no mundo quanto a própria comunicação entre os sujeitos. Suponhamos que estamos na pele de um antropólogo buscando retratar os costumes e práticas de uma tribo isolada no meio da floresta amazônica, cuja língua nós conhecemos de modo limitado. Se o pajé me diz que o sétimo deus acaba de ascender, não tenho como identificar o pensamento expresso pela afirmação, e consequentemente, não tenho como avaliá-lo como verdadeiro ou falso. Mas, se descubro que o que ele se refere como "o sétimo deus" é o Sol, então eu consigo especificar o conteúdo da sua alegação de uma forma que seja informativa para nós: “O pajé afirma, do Sol, que ele acaba de nascer" (BRANDOM, 2001, p. 180). ${ }^{78}$

\subsubsection{Verdade}

A análise do vocabulário veritativo em função dos elementos da pragmática normativa é relativamente simples, em comparação com a análise fornecida em 4.5.1. Brandom se autointitula um defensor de uma teoria deflacionista da verdade, uma vez que ele sustenta que, apesar de assumirem a forma gramatical de predicado, as expressões veritativas não constituem predicados genuínos (1994, p. $325)$.

\footnotetext{
${ }^{78}$ Brandom ressalta que, do mesmo modo que podemos especificar crenças de re, podemos também especificar intenções de re. Assim, podemos ir de "Nicole pretende atirar naquele cervo" para "Em relação àquela vaca, Nicole pretende atirar nela" (2001, p. 203). No entanto, uma vez que o discurso sobre intenções é tributário ao discurso sobre crenças, essa transição precisa ser mediada pela atribuição de re de uma crença: "Nicole acredita, daquela vaca, que ela é um cervo" (ibidem, p. 203). A especificação de dicto (padrão) de uma intenção é utilizada quando estamos querendo ressaltar o motivo pelo qual o sujeito vai realizar uma ação, enquanto a especificação de re é utilizada quando estamos querendo ressaltar o que o sujeito de fato vai conseguir fazer (ibidem, p. 203).
} 
Dizer de um enunciado que ele é verdadeiro geralmente nada mais é do que endossar um compromisso que atribuímos a outrem:

(...) Para que o registrador tome a alegação atribuída como verdadeira, basta que ele aceite tal alegação. (...) Entender adequadamente o discurso sobre a verdade requer entender exatamente essa diferença de perspectiva social: entre atribuir um status normativo a outro e adotá-lo ou assumi-lo a si mesmo. É a prática de avaliar a verdade das alegações que subjaz à ideia de que conteúdos proposicionais podem ser entendidos em termos de condições de verdade. (BRANDOM, 2001, pp. 168-169)

Ao contrário da análise das expressões referenciais "sobre", "a respeito de...", "do" etc - a análise do discurso veritativo aqui ganha vazão no próprio jogo das fichas coloridas, haja vista que elas costumam ser aplicadas precipuamente a proposições em sua forma não sintaticamente articulada. Assim, por exemplo, se B, vendo que $\mathrm{C}$ jogou vermelho, além de afixar um quadrado vermelho na sua tábua para $\mathrm{C}$, jogar também vermelho, então $\mathrm{B}$ estaria realizando um ato com a mesma força pragmático normativa do ato que nós realizamos ao dizer que um proferimento feito por outrem é verdadeiro.

Essa análise pragmática da verdade concebida por Brandom também proporciona, por meio de sua extensão quase que natural, uma interpretação inferencialista da teoria tripartite do conhecimento: como já foi colocado, a crença é definida em termos de possuir um compromisso; a justificação é definida como ter uma habilitação a possuir um compromisso; e a verdade, por último, como assumir um compromisso de outrem para o qual julgamos estar habilitados para possuí-lo. 


\section{Fundações do significado no inferencialismo e a resposta ao cético}

No capítulo 4, apresentamos a teoria da prática normativa de Brandom como a base para uma teoria semântica inferencialista. No presente capítulo, tomamos novamente o aparato técnico conceitual da teoria da prática normativa, dessa vez para esboçar uma teoria fundacional do significado de estirpe inferencialista.

O sucesso da empreitada realizada no capítulo 3 depende do sucesso da presente empreitada, na medida em que o problema de seguir uma regra se coloca verdadeiramente como um desafio cético para qualquer teoria do significado. Assim, o maquinário apresentado no cap. 3 só pode entrar em funcionamento efetivo se uma teoria fundacional inferencialista se mostrar viável frente a tal desafio.

De fato, a tarefa a ser realizada neste capítulo ainda é a mesma, e, portanto, uma continuação daquela realiza e iniciada no capítulo anterior: mostrar de que modo a linguagem (e o pensamento) estão conectados com a realidade, o que envolve mostrar, antes de mais nada, que eles estão conectados.

\subsection{Intencionalidade e normatividade}

Uma teoria fundacional inferencialista deve ser do tipo que Speaks (2020) classificou como teoria das práticas sociais; o que faz com que um sujeito s queira dizer $\mathrm{x}$ por ' $\mathrm{x}$ ' é um fato relativo a haver uma prática normativa intersubjetiva, que institui regras (ou normas) que governam o uso que s faz de ' $x$ ', bem como estados intencionais de $\mathrm{s}$ envolvendo $\mathrm{x}$. No entanto, a teoria de Brandom incorpora, na explicação acerca da intencionalidade, elementos próprios das chamadas teorias interpretativas, que Speaks (2020) associa sobretudo com as teorias fundacionais de estirpe davidsoniana. Especificamente, a teoria fundacional de Brandom se 
apropria da concepção de Dennett a respeito da intencionalidade, e a adapta tendo em vista sua própria teoria da prática normativa.

\subsubsection{A postura (stance) intencional}

Oferecer uma explicação a respeito do que é a intencionalidade é, em poucas palavras, uma tarefa tão filosoficamente relevante quanto árdua. Uma tal explicação, de acordo com os autores da Escola de Pittsburgh, pode ser considerada a chave não só para o problema de seguir uma regra, como para outros problemas céticos mais clássicos que mencionamos no capítulo 2 .

Brandom adota, e imputa também ao próprio Dennett, uma estratégia explicativa que ele chama de fenomenalismo metodológico (1994, p. 597); a ideia é que, a fim de compreendermos um vocabulário $\mathrm{K}$, nós utilizemos o vocabulário de considerar como, ou tomar como (to take as) $K$ como conceitualmente anterior a (ser) $K$ (ibidem, pp. 291-292). O caráter metodológico do fenomenalismo aqui se deve exatamente ao fato de que a prioridade conceitual do discurso do "ser como K" sobre o "ser K" não implica de forma alguma prioridade ontológica do primeiro sobre o último. Ou seja, um (ser) K definido através dessa estratégia pode existir independentemente de que exista algo que (seja) como K. O “(ser) K” aqui é entendido por meio do entendimento prévio do que é "como (ser) K”, mas não é definido em termos de "como (ser) K". ${ }^{79}$

No que tange especificamente à questão da intencionalidade, Dennett sustenta que não há espaço para outra noção de sistema intencional do que a de ser adequadamente tratado como um sistema intencional. E tratar algo (um objeto que constitui algum tipo de sistema) como intencional, para Dennett, consiste em considerar que seus comportamentos são manifestações de crenças, desejos, intenções etc. (entre outros estados com conteúdo proposicional):

Eu gostaria de examinar o conceito de um sistema cujo comportamento pode ser - pelo menos às vezes - explicado e predito ao dependermos de atribuições ao sistema de crenças e desejos (e esperanças, medos, intenções, palpites...). Eu chamarei tais sistemas de sistemas intencionais, e tais explicações e predições de explicações e predições

\footnotetext{
${ }^{79}$ Uma definição de "ser K" em função de "ser-como K" seria tipicamente expressa por meio de um enunciado analítico, onde o definiendum seria tanto conceitual quanto ontologicamente prioritário em relação ao definiens. Diríamos, nesse caso, que o fenomenalismo em questão é ontológico. $\mathrm{O}$ caso mais famoso - embora não o único - de fenomenalismo ontológico envolve aquilo que aludimos anteriormente (cf. 2.1.1) como ontologia fenomenalista: uma proposição empírica Fa seria definida como sendo verdadeira quando ela parece verdadeira para um sujeito sob certas condições, ou seja, quando o sujeito possui uma certa experiência sensorial sob certas condições.
} 
intencionais, em virtude da intencionalidade do discurso sobre (idiom) crenças e desejos (e esperança, medo, intenção, palpite). (DENNETT, 1981, p. 3)

Essa atitude que nós temos para com algumas coisas, de tratá-las como manifestando estados intencionais é chamada por Dennett de postura intencional (intentional stance). E a adoção de tal postura envolve, sem dúvida, um compromisso com uma espécie de instrumentalismo: atribuímos estados intencionais - cognitivos e conativos - a objetos como um meio de realizar predições e explicações acuradas a respeito do comportamento desses objetos:

(...)Alguém prevê o comportamento em um tal caso ao atribuir ao sistema a posse de certas informações e supor que ele seja dirigido por certas metas, e então realizar a ação mais razoável ou apropriada com base nessas atribuições e suposições. É um pequeno passo chamar as informações possuídas por um computador de crenças, e suas metas e submetas de desejos. (A) noção de informação (...) é tão intencional quanto aquela de crença. (DENNETT, 1981, pp.6-7)

Agora, Dennett sustenta que o poder explicativo da postura intencional não surge de maneira direta. De acordo com Dennett, os estados intencionais apontam diretamente apenas para o que o objeto de atribuição deveria fazer. Ou seja, dados os estados intencionais que nós atribuímos a um objeto, podemos inferir - ceteris paribus - quais comportamentos seria apropriado e racional tal objeto manifestar.

Para extrair predições a partir de avaliações normativas, que dizem respeito a estados intencionais, Dennett precisa de uma premissa adicional, chamada de assunção da racionalidade substantiva (1981, pp.5-6): um sistema intencional costuma, com grande frequência, se comportar de maneiras que ele deveria se comportar, a luz dos seus próprios estados intencionais. Brandom, ao comentar as colocações de Dennett, diz:

Ser racional no sentido de Dennett é agir como alguém deveria agir racionalmente, agir como os estados intencionais desse alguém o comprometem ou o obrigam a agir. A fim de derivar predições de comportamento atual a partir de estados intencionais, é necessário adicionar a assunção de que o sujeito ao qual os estados são atribuídos é racional nesse sentido. Em outras palavras, a interpretação intencional oferece uma explicação intencional primária dos status normativos de quem é interpretado, uma explicação de quais performances são apropriadas à luz das crenças e preferências atribuídas. Suplementada por uma assunção de racionalidade substantiva, essas caracterizações normativas podem ser usadas para fundamentar predições sobre performances atuais, produzindo uma explicação intencional secundária do comportamento descrita em termos não normativos. (BRANDOM, 1994, p. 57)

A postura intencional e a assunção da racionalidade substantiva nos permitem elucidar plenamente as duas concepções de crença utilizadas dentro de uma abordagem inferencialista. Por um lado, há uma concepção normativa de crença: aquilo em que alguém acredita é considerado como sendo aquilo que seria racional alguém acreditar, do ponto de vista do intérprete ou atribuidor de crenças. Por exemplo, se eu vejo que o meu vizinho está colocando um saco de lixo na sua 
calçada, eu atribuo a ele (juntamente com vários outros estados intencionais, incluindo o desejo que ele tem de se livrar do lixo e manter sua própria calçada limpa) a crença de que o lixeiro recolherá o lixo em breve. Pois, se o seu comportamento é racional no sentido de que ele frequentemente faz o que ele deveria fazer, então é adequado que eu atribua a ele (juntamente com muitos outros estados intencionais) a crença de que o lixeiro passará em breve. Por outro lado, nem sempre é possível interpretar o comportamento de outrem como sendo inteiramente racional. Assim, existe também uma concepção empírica de crença: alguém acredita naquilo que está disposto a expressar por meio de asserções.

Essa dicotomia é bem explicitada na teoria da prática normativa e bem ilustrada no jogo das fichas coloridas: as fichas que jogadores afixam em seus respectivos painéis correspondem ao sentido empírico da crença (os compromissos que eles reconhecem como possuindo); já as fichas que os jogadores deveriam jogar, de acordo com as regras do jogo e com as fichas que eles já jogaram, correspondem ao sentido normativo da noção de crença.

Dennett também busca conciliar aquilo que, seguindo Brandom, estamos chamando de fenomenalismo metodológico, com uma espécie de fisicalismo extensionalista. Em um nível mais básico e específico da descrição das coisas, Dennett sugere que sistemas intencionais devem ser caracterizados em termos de uma postura física (physical stance): um modo próprio de caracterizar as coisas em termos do vocabulário puramente descritivo, e, portanto, não normativo, das ciências naturais (1981, p.5).

Brandom observa, entretanto, que não há como Dennett garantir um "tratamento diferenciado" para explicações de comportamentos em termos de descrições físicas das coisas. Não há uma distinção possível, na própria teoria de Dennnett, entre assumir uma postura física de maneira explicativamente convincente, por um lado, e a realidade mesma das coisas, independentemente da postura que nós adotemos ao caracterizá-la:

Assim poder-se-ia dizer que (...) a diferença entre sistemas físicos e intencionais é ela própria uma diferença normativa, uma questão da adequação de se adotar diferentes posturas preditivas-explicativas em relação ao sistema em questão. No final das contas, algo ser uma amostra de cobre é exatamente algo ser própria ou corretamente tratado enquanto tal por alguém (...), do mesmo modo que algo ser um sistema intencional é algo ser própria ou corretamente tratado enquanto tal por alguém. (...) Segue-se que a estratégia de Dennett de tratar significações normativas de estados intencionais como instituídas por atitudes de intérpretes não envolve por si só o compromisso de reduzir o normativo ao não normativo, na medida em que são adequações de atitudes que são invocadas. $\mathrm{O}$ 
compromisso redutivo vem depois, ao explicar aquelas adequações. (BRANDOM, 1994, p.58)

Poderíamos dizer que, na tensão entre o instrumentalismo e o fisicalismo redutivo dentro da teoria de Dennett, o instrumentalismo prevalece: adotar ou não a postura física em relação a uma descrição é tanto uma questão de adequação quanto adotar uma postura intencional. Assim, tanto a noção de descrição quanto a de adequação são intrinsecamente normativas. Constatamos, desse modo, que Brandom vira a abordagem dennettiana de ponta a cabeça: não é uma caracterização puramente extensional e descritiva das coisas que define o que é uma caracterização normativa, mas o contrário.

\title{
5.1.2. Tipos de intencionalidade
}

Ainda de acordo com Dennett, seres dotados de intencionalidade ("sistemas intencionais") que podem assumir a postura intencional em relação a outros seres tem um tipo especial de intencionalidade (1981, p.17):

\begin{abstract}
Assim como nem todos os sistemas intencionais atualmente conhecidos por nós podem voar ou nadar, nem todos os sistemas intencionais podem falar, mas aqueles que podem fazer isso levantam problemas e oportunidades especiais quando nós chegamos a atribuir crenças e desejos a eles. Essa é uma exposição muito suavizada, uma vez que sem os sistemas intencionais falantes, evidentemente, não haveria nenhuma atribuição de crença, nenhuma teorização, nenhuma assunção de racionalidade, nenhum predizer.
\end{abstract}

Brandom agrega sistematicidade a esses apontamentos ao falar explicitamente em dois tipos de intencionalidade: a intencionalidade de primeira classe, ou original, ou ainda, interpretante; e a intencionalidade de segunda classe, derivada ou simples (1994, pp.59).

A intencionalidade derivada é aquela possuída pelas coisas em relação às quais é adequado tratá-las ou interpretá-las como tendo estados intencionais. É a intencionalidade atribuída por um intérprete, como por exemplo, a intencionalidade que é atribuída aos animais, a crianças de colo e a computadores (se realmente fizer sentido fazer isso, como Dennett pensa fazer).

A intencionalidade original, por sua vez, é aquela possuída pelas coisas capazes de elas próprias adotarem a postura intencional, isto é, a intencionalidade do intérprete (ibidem, p. 59). Apenas as coisas que possuem intencionalidade original utilizam conceitos manifestos através da linguagem - como nós seres humanos cognitivamente desenvolvidos. Apenas as coisas que possuem intencionalidade original habitam tanto o domínio da natureza quanto o domínio da cultura.

A proposta de Dennett deve ser complementada, segundo Brandom, ainda 
com uma espécie de terceiro tipo de intencionalidade, cuja posse não envolve nenhuma atribuição de estado intencional: é a intencionalidade possuída paradigmaticamente por tokens linguísticos, como sequências sonoras e inscrições em superfícies (ibidem, p.60). Ainda, esse é o tipo de intencionalidade que faz com que um certo estado de uma coisa seja precisamente um estado intencional - por exemplo, faz com que eu possa conceber certas imagens mentais interiores como sendo sobre certo objeto. Ao contrário das coisas que possuem os outros dois tipos de intencionalidade, em relação as quais atribuímos estados intencionais, as coisas que possuem esse terceiro tipo de intencionalidade - sons, inscrições, imagens possuem conteúdo intencional.

Poderíamos dizer com certa segurança que a ideia de Dennett e Brandom, que o segue neste ponto, é explicar uma coisa possuir conteúdo intencional em função de uma outra coisa possuir estados intencionais. Especificamente, explicar o conteúdo intencional em função dos estados intencionais dos seres dotados de intencionalidade original.

\subsubsection{Implícito e explícito}

Até agora, estivemos falando da relação implícito/explícito de uma maneira mais informal, embora não tenha havido prejuízo explicativo por isso. Apontamos que status deônticos, atitudes deônticas e regras estão implícitas quando não foram até então linguisticamente expressas pelos sujeitos da prática por meio do uso de um vocabulário apropriado para isso. A explicitação do que está implícito só pode ser feita, necessariamente, através do uso de metalinguagem sintaticamente articulada contando com vocabulário lógico e, como um derivado deste último, um vocabulário normativo.

Via de regra os jogos não incluem como parte da própria linguagem do jogo esse superestrato metalinguístico capaz de tornar explícitos os status, atitudes e regras em questão. Consideremos o jogo de xadrez, por exemplo: fazem parte do léxico do jogo as próprias peças e algumas palavras - como "xeque" - que podem ou devem ser utilizadas em situações específicas. Os lances válidos do jogo são sempre realizados por meio da utilização, por parte dos jogadores, de um token físico que é parte desse léxico. Ecoando as observações de Wittgenstein nas Investigações, diríamos que indicações do que um jogador pode ou não fazer e referências às regras do jogo não são elas próprias lances do jogo. Se eu digo ao 
meu adversário que um peão não pode voltar no tabuleiro, minha fala é “extrajogo".

Mesmo em jogos onde tokens são usados para indicar status deônticos, como placares, o fato de o jogo não incluir uma metalinguagem implica que tais status ainda são, a rigor, implícitos. Isso vale também para o nosso hipotético jogo das fichas coloridas, pois as fichas coloridas, tábuas e campainhas funcionam exatamente como as peças do xadrez e placares de jogos esportivos. Quando A e B afixam um círculo colorido nas suas respectivas tábuas para $\mathrm{C}$, o que temos aí é um modelo de explicitação de registro de pontos; mas isso não é, pelos próprios critérios da teoria prática normativa de Brandom, uma explicitação de registro de pontos.

Uma decorrência de adotarmos a "postura da postura" é que deixa de existir qualquer diferença que poderíamos chamar de intrínseca entre uma coisa apresentar um comportamento normativo implícito, por um lado, e um mero padrão ou regularidade natural, por outro. Uma coisa integra uma prática normativa sempre que foi adequado tratarmos ela dessa forma.

Isso significa, em primeiro lugar, que não é uma condição necessária para considerar que algo está manifestando um comportamento implicitamente normativo, que esse algo possua uma linguagem expressivamente completa - isto é, uma linguagem que conte com os vocabulários normativo e metalinguístico que o permita explicitar regras através de enunciados gramaticais:

Atribuir este tipo de significação [asserção] a performances é tratá-las como tornando explícita a adoção de status normativos - ou seja, reconhecer (assumir) um compromisso doxástico ao dizer aquilo com o que alguém está comprometido. Acompanhar a pontuação discursiva de outrem é adotar atitudes deônticas - isto é, atribuir compromissos discursivos ao implicitamente ou na prática considerar ou tratar outrem como comprometido. Tal registro de pontos (e assim prática linguística genericamente) não exige que alguém seja capaz de explicitamente atribuir status deônticos - dizer (asserir) que alguém está comprometido com a alegação de que $p$. As locuções lógicas cujo papel expressivo é tornar a adoção de tais atitudes pragmáticas explícita na forma de conteúdo alegáveis - vocabulário atribuidor de atitudes proposicionais tal como o arregimentado “... está comprometido com a alegação que ...” ou seu correlato vernacular "... acredita que ..." - formam um superestrato opcional cujo papel expressivo pode ser entendido em termos do que está implícito no nível fundamental da prática linguística, mas que não é exigido para, ou pressuposto pela prática. (BRANDOM, 1994, p. 629)

Brandom considera que mesmo seres sem nenhuma capacidade linguística e conceitual estão implicitamente seguindo regras (normas). $\mathrm{O}$ fato de que a intencionalidade que atribuímos a abelhas, esponjas marinhas e (quem sabe) plantas e computadores é a intencionalidade derivada não nos impede de vermos tais coisas como genuinamente fazendo parte de práticas normativas. Comportamentos naturalmente (ou artificialmente, no caso dos artefatos) regulares serão manifestação de práticas normativas implícitas sempre que existirem seres como 
nós, adotando a postura intencional em relação a essas coisas - ou seja, sempre que houver seres sapientes, portanto dotados capacidade de expressiva, de explicitação, "projetando" a normatividade sobre outros seres:

(...) é possível para aqueles que são registradores discursivos atribuir um tipo derivado de status e atitudes discursivas com conteúdo proposicional a criaturas não linguísticas. Isto é adotar a postura intencional simples de interpretar algo como um sistema intencional simples ou prático. Quando esta postura é adotada, o intérprete mantém um tipo simplificado de pontuação deôntica, ao atribuir compromissos com conteúdo proposicional, tanto práticos quanto doxásticos, que o sujeito é considerado como reconhecendo implicitamente em seu comportamento. Suas performances, disposições e regularidades comportamentais podem ser tornadas inteligíveis ao atribuir fragmentos amostrais de raciocínio prático (...). O registro de pontos envolvido é simplificado visto que adotar a postura intencional simples não envolve atribuir atos de fala; ela não envolve nem mesmo implicitamente tratar o sistema em questão como ele próprio capaz de registrar pontos (atribuir e não apenas reconhecer status deônticos) (...). (BRANDOM, 1994, p.629-630)

\subsubsection{Três níveis da normatividade de uma prática}

A estrutura de uma prática possui três níveis de normatividade: (i) status deônticos;

(ii) atitudes deônticas; e (iii) atitudes interpretativas. Nas palavras do autor (1994, pp. 637-638):

Normas entram na história em três diferentes lugares: os compromissos e habilitações que os membros da comunidade são considerados como atribuindo uns aos outros; as adequações práticas implícitas do registro de pontos com atitudes, que instituem aqueles status deônticos; e a questão de quando é apropriado ou correto interpretar a comunidade como exibindo intencionalidade original, ao atribuir práticas discursivas particulares de registro de pontos e atribuir status deônticos. A postura normativa é ladeira abaixo (all the way down).

Quando nós, que possuímos todos os recursos expressivos necessários para explicitar o que normalmente está implícito em uma prática normativa, adotamos a atitude interpretativa, nós consideramos as performances de outrem como expressando atitudes deônticas: nós consideramos muitos dos comportamentos exibidos pelos objetos da atitude interpretativa como constituindo a realização de um registro de pontos mais ou menos nos moldes do jogo das fichas coloridas. Se eu interpreto os sons emitidos por um companheiro como tendo a significação pragmática de uma alegação, então eu estou considerando que ele está habilitando a mim e aos demais a atribuir a ele o compromisso que a alegação expressa. E dizer que ele está habilitando a mim e aos demais a atribuir-lhe um compromisso é justamente tomar a sua performance (a emissão de uma certa sequência sonora) como manifestando uma atitude deôntica.

Agora, uma atitude deôntica tem ela própria um objeto, que é não apenas um compromisso isoladamente, mas o conjunto de compromissos que é atribuído a 
alguém em um certo momento. Atitudes deônticas fazem referência aos status deônticos dos sujeitos da prática. Se o companheiro atribui um compromisso a si próprio ao fazer uma alegação, então ele está acrescentando um compromisso ao estoque de compromissos possuídos que constitui o seu status deôntico. E ele também está acrescentando ao estoque de compromissos de todos os demais companheiros a habilitação a assumir aquele compromisso, bem como a habilitação para realizar um lance de atribuição de compromisso a ele próprio. Notemos que o real status deôntico de um sujeito da prática em um determinado momento não pode ser reduzido às atitudes deônticas que os demais sujeitos de fato tem em relação a ele. Como bem salienta o autor:

Regularidade de comportamento e disposição comunais especificadas em termos não normativos não podem ditar a atribuição de práticas de registro de pontos que instituem um conjunto particular de status normativos e conferem um conjunto particular de conteúdos proposicionais. Ao adotar tal postura, o intérprete considera os interlocutores como estando comprometidos em registrar pontos de acordo com padrões específicos, associando significações pragmáticas com performances discursivas que correspondem aos conteúdos inferencialmente articulados dos compromissos doxásticos e práticos que eles expressam. (...) Tais compromissos por parte do intérprete são compatíveis com uma falta de ajuste infinitamente grande entre as normas atribuídas e as reais performances daqueles aos quais elas são atribuídas, incluindo a performance deles em avaliar uns aos outros. (...) (1994, p. 638)

Ou seja, o que alguém está comprometido, habilitado a e precluso a se comprometer é algo que independe de como ele é julgado como comprometido, habilitado a e precluso a se comprometer. Atitudes normativas elas próprias compõem os status deônticos, e, portanto, elas próprias são passíveis de serem adotadas correta ou incorretamente.

Então, podemos dizer que status deônticos são objetos de atitudes deônticas, e que estas, por sua vez, são objetos de atitudes interpretativas: adotar uma atitude interpretativa implica em atribuir a alguém a adoção de atitudes deônticas, e adotar uma atitude deôntica implica ainda em atribuir status deônticos - tanto a si mesmo quanto a outrem. Por essa perspectiva, o nível mais básico da estrutura normativa de prática é o dos status deônticos, e o menos básico é o da atitude interpretrativa; falamos sobre status deônticos como objetos per si, sem pressupor nenhum outro nível.

Porém, esses mesmos três níveis normativos podem ser vistos de uma perspectiva simetricamente invertida. Atitudes interpretativas instituem atitudes deônticas, que por sua vez instituem status deônticos. A existência de uma prática normativa depende da realização regular de comportamentos que são adequadamente interpretados como instituindo atitudes deônticas; os status 
deônticos, são constituídos pelas atitudes deônticas continuamente mantidas pelos membros da prática; status deônticos, bem como as regras que os governam, são criaturas dessas atitudes.

Ambas as perspectivas são igualmente essenciais para a compreensão da estrutura de uma prática normativa, de modo que não há prioridade de uma perspectiva em relação a outra. As regras que determinam quais são os reais status deônticos dos sujeitos, e quais atitudes deônticas eles devem adotar uns em relação aos outros são objetivas no sentido da independência do juízo (IJ) de Wright, que vimos na seção 2.3 desta tese. Por outro lado, status deônticos e as regras que os determinam são produtos da atividade de seres sapientes e não são nenhum tipo de entidade fantasmagórica e possivelmente transcendente à compreensão desses seres.

\subsubsection{A escada da intencionalidade}

A distinção entre seres intencionais e não intencionais, bem como aquela entre intencionalidade original e derivada, não deve ser tratada inteiramente como sendo de natureza. Em alguma medida, estas diferenças devem ser tomadas como sendo de grau: seres em relação aos quais adotamos a postura intencional tem as características dos seres em relação aos quais adotamos outros tipos de posturas mais algumas outras características. Igualmente, seres em relação aos quais atribuímos a intencionalidade original tem as características dos seres aos quais atribuímos intencionalidade derivada, mais algumas outras.

E essa linha de raciocínio não é incompatível nem mesmo com a visão mais instrumentalista proposta por Dennett. Podemos dizer, dos seres intencionais, que eles são de alguma forma complexos demais para que a adoção de outras posturas (física ou do desígnio) sejam ao mesmo tempo manejáveis por nós e explicativamente acuradas (DENNETT, 1981, p. 5).

Podemos representar tais diferenças através de uma escada. O degrau mais baixo, imediatamente acima do "solo" não intencional, é reservado para aqueles serem que possuem o tipo mais básico de intencionalidade derivada. $\mathrm{O}$ degrau mais alto, por sua vez, é aquele destinado aos seres que atingiram aquilo que Brandom chama de completude expressiva, ou seja, seres que possuem uma linguagem articulada e suficientemente rica para tornar explícito virtualmente tudo que possa estar implícito na prática normativa de qual participam. Nós, enquanto sapientes 
cognitivamente maduros e inseridos na cultura, estamos obviamente neste último degrau, tendo o domínio dos conceitos lógicos e normativos expressos em uma linguagem articulada e complexa, e sendo capaz de adotar a postura intencional em relação aos seres que estão abaixo nessa escada.

Agora, entre o mais alto e o mais baixo degrau há também degraus intermediários, e a partir de que degrau passamos da intencionalidade derivada para a original é algo cuja discussão fica em aberto. Os padrões naturais de comportamento que os animais exibem - como a construção de ninhos por passarinhos e de estocagem de nozes por esquilos - são interpretados por nós como manifestando uma intencionalidade que obviamente não é original; projetamos pensamentos em pássaros e esquilos como estando por detrás dos comportamentos relativamente inteligentes que eles exibem. Mas o que dizer de crianças pequenas, que ainda não dominam o vocabulário expressivo lógico e normativo, mas conseguem articular frases curtas e realizar inferências? É difícil negar que elas já sejam membros da nossa prática linguística plenamente desenvolvida, já que seus proferimentos são de fato lances do nosso jogo de linguagem.

Uma outra questão importante é se há algum tipo de restrição de natureza aos seres aos quais nós atribuímos intencionalidade e colocamos em um dado degrau. Brandom segue em grande medida o "liberalismo" de Dennett e parece disposto a atribuir intencionalidade derivada não apenas a animais, mas também a plantas, e mesmo a micróbios e artefatos rudimentares - como termostatos. Ele também parece disposto a conceder a robôs e computadores intencionalidade original, na medida em que eles sejam dotados de uma linguagem expressivamente completa. Por outro lado, Sellars oferece mais uma vez uma abordagem mais estrita: a intencionalidade, seja ela original ou derivada, só deve ser atribuída a seres capazes de algum tipo de sistema representacional inato. Ele tende a ver a posse de estados intencionais dentro de um processo adaptativo de evolução dos seres vivos, cujas linguagens naturais expressivamente completas são seu produto (cf SELLARS apud DEVRIES, 2005, 188-190).

\subsubsection{Intencionalidade original e equilíbrio interpretativo}

Para nós seres humanos, enquanto sapientes ocupando o degrau mais elevado da escada da intencionalidade, não há diferença entre adotarmos a atitude interpretativa uns em relação aos outros e adotarmos atitudes deônticas uns em 
relação aos outros. Isso porque tratar um objeto como sujeito de uma prática é exatamente considerar que tal ser atribui intencionalidade original e atitudes deônticas em relação a outrem através dos recursos expressivos do vocabulário lógico e normativo. Em realidade, nossas atitudes deônticas são constituídas precisamente pela projeção recíproca que fazemos uns em relação aos outros de intencionalidade.

Brandom diz que quando os membros de uma prática adotam explicitamente a atitude interpretativa uns em relação aos outros, então a comunidade de membros atingiu o equilibrio interpretativo (1994, p. 642):

Os membros de uma comunidade linguística que adotam a postura do registro de pontos explícita uns em relação aos outros alcançam desse modo um tipo de equilibrio interpretativo. Cada um interpreta o outro como engajado exatamente no mesmo tipo de atividade interpretativa, como adotando exatamente o mesmo tipo de postura interpretativa que se adota em relação a si próprio. Este considerar-outros-como adotando-exatamente-os-mesmos-tipos-de-atitudes-que-se-adota em-relação-a-simesmo simétrico, característico da postura do registro de pontos discursivo, contrasta marcadamente com a relação $a$ ssimétrica que existe entre o intérprete que adota a postura intencional simples e as criaturas não linguísticas interpretadas como um sistema intencional simples. Nesse caso o intérprete não considera o sistema que está sendo interpretado como capaz de fazer exatamente aquilo que o intérprete está fazendo, a saber atribuir (como oposto a reconhecer) crenças, intenções, e o endosso de padrões de raciocínio prático.

Brandom também sustenta que a atribuição de intencionalidade original

deve ser feita sempre que puder ser feita (1994, p. 644):

(...) alguém deveria (ought to) adotar a postura de registro de pontos discursivos sempre que pudesse adotá-la. (...) as detalhadas exigências que alguém deve satisfazer a fim de que possa contar como adotando uma tal interpretação são rigorosas. Não é qualquer grupo de organismos que interagem entre si que pode ser entendido como se eles estivessem atribuindo uns aos outros compromissos cuja articulação inferencial e social baste para que se conceda conteúdos genuinamente proposicionais às suas performances. Assim, há pouco perigo de uma tal política generosa levar a uma extensão complacente ou promíscua da franquia da sapiência aqueles que não a merecem.

De acordo com o autor, as exigências para que uma tal atitude possa ser adotada são elas mesma elevadas. A comunidade na qual o objeto de atribuição está inserido deve ter obrigatoriamente atingido a completude expressiva, de modo que o atribuidor possa discriminar com razoável sucesso os tokens linguísticos para conceitos lógicos e normativos. Além disso, a atribuição de intencionalidade original envolve sempre a promessa de uma boa "recompensa" (1994, p. 244):

(...) a recompensa por adotar a atitude de registro de pontos discursivos sempre que possível é grande. Conversação é o grande bem (the great good) para criaturas discursivas. Estendê-la aumenta nosso acesso à informação, nosso conhecimento e nosso entendimento - nossa autoconsciência semântica e pragmática.

quanto maior for a comunidade dos sapientes, mais chances nós temos de obter conhecimento e informação sobre a realidade. 


\subsection{Ceticismo semântico e o inferencialismo}

$\mathrm{O}$ que o cético do WK teria a dizer a respeito das propostas inferencialistas para a teoria do significado? Que tipo de acusação o cético faria a Brandom e Sellars? E como o inferencialismo poderia responder ao desafio cético?

Como começamos a vislumbrar no capítulo anterior, uma resposta inferencialista ao desafio cético (tal como a resposta do próprio WK) tem o caráter de um argumento da linguagem privada. Fatos constitutivos do conteúdo intencional e da significação linguística são produtos da interação de sujeitos - seres sapientes - tanto entre si quanto com o ambiente. É exigida uma pluralidade de sujeitos, pois, como vimos, uma prática se constitui a partir da adoção de atitudes deônticas dos sujeitos uns em relação aos outros. Nesse sentido, a ameaça de um regresso ao infinito de atitudes interpretativas é evitada exatamente pelo fato de que os sujeitos projetam interpretações uns em relação aos outros, e elas são geralmente congruentes. Atribuímos uns aos outros - geralmente - os mesmos compromissos, habilitações a compromissos e proibições de compromissos.

Por outro lado, fatos semânticos não são redutíveis ao conjunto de atitudes que os sujeitos adotam uns em relação aos outros, como nas leituras antirrealistas da solução cética do WK. A realidade, com seus eventos e objetos, entra ela própria como ingrediente na constituição de fatos semânticos. O inferencialismo de Pìttsburgh é um tipo de realismo semântico, e a verdade ou falsidade de enunciados do discurso semântico é independente do juízo (IJ). Assim, como a própria noção de verdade integra o discurso semântico, segue-se que o valor de verdade dos enunciados de qualquer linguagem (e as crenças que são a contraparte "interna" de tais enunciados) é sempre independente de juízo (IJ). O inferencialismo nos oferece assim o grau de realismo que procurávamos: suficientemente realista para escapar do relativismo, porém não tão realista a ponto de sermos presa fácil para o ceticismo. $^{80}$

Poderia a resposta inferencialista satisfazer o cético do WK? Levando em conta as observações de Hattiangadi sobre o tema, uma resposta inferencialista cairia na vasta e heterogênea família das chamadas respostas primitivistas ao problema de seguir uma regra: fatos semânticos/intencionais seriam sui generis e

\footnotetext{
${ }^{80} \mathrm{Na}$ medida em que o meu querer dizer adição por “+” é constituído não apenas pelas atitudes de outros sujeitos da comunidade como também pelo próprio mundo real, o inferencialismo é também uma forma de externalismo semântico.
} 
irredutíveis a qualquer outro tipo de fato.

As respostas primitivistas, entretanto, enfrentam a acusação de terem caído em um dos dois chifres do dilema que, segundo Hattiangadi, em última análise constituem o desafio cético. Ou nós somos levados a tomar fatos semânticos como sendo (redutíveis a) fatos naturais, e desse modo incorremos na falácia naturalista. Ou nós somos levados à posição de que fatos semânticos são um tipo de fato não natural envolvendo regras fora do mundo natural guiando a conduta dos sujeitos e então incorremos em uma extravagância metafísica. Por serem normativistas, Sellars e Brandom teriam então sucumbido ao segundo chifre do dilema ${ }^{81} \mathrm{O}$ ônus de mostrar que a existência de fatos semânticos / intencionais primitivos sui generis não é "estranha" e incompatível com uma visão de mundo naturalista está com o inferencialismo.

\subsection{A normatividade no mundo natural}

O naturalismo é a motivação por trás da nossa rejeição ao chifre da "estranheza" no dilema apontado por Hattiangadi; tal rejeição à "estranheza" é ainda uma instância mais geral de um posicionamento contra a existência de entidades não naturais, isto é, desconectadas inteiramente do domínio físico espaço-

\footnotetext{
${ }^{81}$ É curioso como o veredito da própria Hattiangadi a respeito da resposta de Brandom para o problema de seguir uma regra é vacilante. Ela aborda a resposta de Brandom no sexto capítulo de Oughts and Thougts, dedicado às respostas primitivistas ou antirreducionistas, o que está alinhado com a nossa avaliação. No entanto, na seção do referido capítulo dedicada a Brandom, ela por vezes o trata como se ele fosse na verdade um disposicionalista - portanto um reducionista - enrustido. Ela descreve a teoria brandominiana da seguinte forma: "Status normativos são explicados em termos de atribuições de status, e atribuições são por sua vez explicadas em termos de atitudes práticas de considerar ou tratar algo como tendo certo status. Finalmente, essas atitudes são explicadas em termos de disposição a sanção, a responder de certos modos a certos comportamentos. (...) Consequentemente, tratar alguém como tendo certo status exige somente uma habilidade de discriminar características do ambiente ao sancioná-lo diferencialmente. Além disso, essas disposições para a adoção de atitudes: a disposição de impor sanções equivale às (amounts to) 'atitudes práticas de considerar ou tratar alguém como comprometido ou habilitado'. (...) Apesar do uso de Brandom de uma linguagem conspicuamente normativa para descrever as práticas dos protohominídios, sua imagem é em grande medida, ou talvez mesmo inteiramente, fundada em disposições: status normativos são sempre derivados de atitudes normativas, e as últimas são explicadas em termos de discriminação responsiva e propensões a sanção. Uma vez que essas práticas instituem o conteúdo conceitual, os ingredientes são postos juntos para a explicação do conteúdo conceitual. A questão é como isso poderia evitar as objeções contra o disposicionalismo?" (2007, pp. 163-164) Sob a luz de tudo o que já foi apresentado nessa tese a respeito da teoria brandominiana, a ideia de que atitudes deônticas equivalem a disposições a sanção é simplesmente falsa: a posse por um sujeito de disposições responsivas diferenciadas é realmente constitutiva da, porém não esgota e não equivale a posse de um conceito. Desse modo, Brandom é realmente um primitivista, e a dificuldade que sua teoria enfrenta está realmente associada com o problema da estranheza metafísica.
} 
temporal. Mais especificamente, o aspecto do naturalismo que está em questão aqui é o que Papineau denomina de fechamento causal ou completude causal do físico: todos os efeitos físicos têm causas inteiramente físicas; todas as entidades espaçotemporais ou devem ser idênticas a, ou metafisicamente constituídas por entidades físicas (2020). ${ }^{82}$

Porque as repostas não-reducionistas ou primitivistas parecem implicar a existência de coisas sem eficácia causal que de algum modo guiam ou determinam o comportamento de seres inteligentes, tais respostas implicariam uma violação explícita do fechamento causal. E, como bem pontua Papineau (2020), o princípio do fechamento causal não é uma tese fácil de abrir mão, mas, pelo contrário, constitui um elemento essencial do estoque de conhecimento fornecido pelas ciências naturais. Desde o século 19 a tese de que a quantidade total de energia cinética e potencial no universo permanece constante é aceita como um princípio básico da física, precluindo a incidência de qualquer acréscimo (ou decréscimo) "exógeno" de energia implicado pela postulação de causas sobrenaturais.

Muitos dos proponentes de soluções não-reducionistas para o problema de seguir uma regra não têm grande estima por aquilo que aqui estamos chamando de naturalismo. Este é o caso, por exemplo, dos autores alinhados com a postura mais quietista e deflacionada que é peculiar aos trabalhos do segundo Wittgenstein. Um wittgensteiniano ortodoxo provavelmente diria que nossa adesão ao princípio do fechamento causal é uma extrapolação indevida de uma regra própria do jogo de linguagem específico das ciências naturais. Além disso, para aqueles que seguem à risca a cartilha metodológica do segundo Wittgenstein, a filosofia se esgotaria na análise conceitual e não deveria ter qualquer compromisso adicional em operar uma síntese da visão de mundo fornecida pelas ciências (e das ciências entre si) com a visão do senso comum. Não haveria, portanto, qualquer estranheza metafísica a ser neutralizada na ideia de que há regras e fatos normativos, e o dilema cético proposto por Hattiangadi seria simplesmente dissolvido. ${ }^{83}$ Mas esta não é de forma

\footnotetext{
${ }^{82}$ Papineau define como naturalismo ontológico o tipo de naturalismo que tem o princípio do fechamento causal como o seu fundamento, e o diferencia do naturalismo metodológico, que sustenta a pertinência do emprego de métodos próprios das ciências naturais na prática filosófica (2020).

${ }^{83}$ Notemos, entretanto, que recentemente tem ganhado espaço a ideia de que o segundo Wittgenstein teria defendido uma espécie "não científica" ou "liberal" de naturalismo. Ver MCARTHUR, 2018 e HUTTO \& SATNE, 2018 in CAHILL \& RALEIGH, caps 1 e 2.
} 
alguma a postura dos inferencialistas de Pittsburgh. Ao destrinchar os aspectos mais genéricos da filosofia de Sellars, DeVries chega a dizer que o seu compromisso filosófico mais profundo é com o naturalismo (2005, p. 16). Brandom é mais discreto e não reivindica tal rótulo para si: apesar de algumas vezes utilizar os termos "naturalismo" e "naturalista" de maneira estrita para se referir exclusivamente a posições reducionistas (1994, pp. 12 e 42, por exemplo) sua postura em geral não difere substantivamente da postura de Sellars. De qualquer forma, ambos poderiam ser genericamente classificados como "naturalistas não reducionistas". Assim, a conciliação entre normativismo e naturalismo, exigida por Hattiangadi, acaba por ser uma obrigação a ser reconhecida dentro do próprio quadro de referência mais geral dentro qual o inferencialismo floresce - embora também seja correto apontar que nenhum dos autores se dedicou de modo explicitamente sistemático a tal empreitada.

\subsubsection{Superveniência do normativo ao natural}

A principal ferramenta teórica desenvolvida na seara da filosofia da mente na segunda metade do século 20 foi sem dúvida o conceito de superveniência. Embora haja uma série de detalhes e complicações técnicas atinentes a essa noção, uma explicação sucinta seguida de um exemplo deve ser o suficiente para os nossos propósitos.

De maneira geral, podemos definir superveniência como um tipo de relação entre (conjuntos de) propriedades. Dado um objeto qualquer e duas propriedades que ele possua, A e B, A sobrevém ou supervém a B se e somente se qualquer alteração concernente a A implica uma alteração concernente a B. De acordo com McLaughlin (in SAVELLOS \& YALCIN, 1995, p. 18):

\footnotetext{
'a ideia central de superveniência' é a ideia de variação-dependente (...). Variação a respeito de $\mathrm{A}$ depende de variação a respeito de $\mathrm{B}$ de modo que coisas concernentes a $\mathrm{A}$ não podem variar sem variação concernente a B. Variação em aspectos-A supervenientes exige variação em aspectos-B subvenientes. Aspectos-A falham em sobrevir a aspectos$\mathrm{B}$ quando e somente quando aspectos-A podem variar independentemente de variações em aspectos-B.
}

Para mostrar como o conceito se aplica na prática, McLaughlin (2020) nos pede para imaginarmos o caso de um falsário perfeito, cujas cópias de pinturas enganam não somente colecionadores e mercadores de arte, mas são duplicadas exatas de seus originais até o nível preciso da posição de cada uma das moléculas dos pigmentos utilizados: 
Suponha que ele (o falsário perfeito) produza uma cópia de Uma visão de Toledo, de El Greco. Ela é evidentemente diferente da original em vários aspectos - ela é uma falsificação, não foi pintada por El Greco, vale muito menos na Sotheby's e assim por diante. Mas a falsificação é também exatamente como a original em outros aspectos. É da mesma forma, tamanho e peso. A superfície da tela contém os mesmos arranjos de cores e formas - um retângulo azul aqui, um redemoinho verde ali. De fato, elas parecem exatamente idênticas, pelo menos a um único observador sob condições idênticas de iluminação e assim por diante. (...)

As propriedades que é assegurado à falsificação compartilhar com a original são aquelas que sobrevém às suas propriedades microfísicas. As duas pinturas que são exatamente semelhantes do ponto de vista microfísico é assegurado serem exatamente semelhantes no arranjo de cores e formas em suas telas. Ou seja, você não pode mudar o arranjo de cores e formas na tela da pintura sem mudar suas propriedades microfísicas. Isto é exatamente dizer que o arranjo de cores e formas sobrevém à suas propriedades microfísicas.

As propriedades supervenientes são chamadas, no vocabulário técnico da superveniência, de propriedades de alto nível, enquanto as propriedades subvenientes são chamadas de propriedades de baixo nível. No nosso exemplo tomado de McLaughlin, as propriedades de alto nível são as propriedades qualitativas da tela pintada - o arranjo de cores e formas, dimensão... enquanto as propriedades de baixo nível são suas propriedades físico-químicas - as moléculas dos pigmentos depositados sobre a tela e o arranjo entre elas, as moléculas da própria tela e o arranjo delas etc.

Uma importante dimensão do conceito de superveniência é ainda a ideia de realizabilidade múltipla das propriedades de alto nível pelas propriedades de baixo nível: diferentes propriedades-B (ou conjuntos de) podem ser subvenientes a uma mesma propriedade-A (ou conjuntos de). Imaginemos agora o caso de um falsário quase-perfeito: sua cópia de Uma visão de Toledo de El Greco que tem todas as propriedades qualitativas do original e nenhuma propriedade que o original não possua, mas que seja diferente dessa última em pelo menos algumas propriedades físico-químicas. A cópia quase perfeita tem o mesmo peso, dimensão, arranjo de cores, saturação etc. Ela é de fato indistinguível da original a olho nu, e mesmo sob o escrutínio de alguns instrumentos bem precisos, como um microscópio óptico. A fraude, no entanto, é detectável com o auxílio de equipamentos capazes de perscrutar suas micropropriedades. As substâncias utilizadas como tinta são diferentes, de maneira que os tipos de moléculas que compõem a pintura original e a cópia são diferentes. Dizemos então que as propriedades qualitativas de alto nível são multiplamente realizáveis pelas propriedades físico-químicas de baixo nível da tela.

É importante salientar que uma propriedade A (de alto nível) não é a mesma 
coisa que a disjunção de propriedades B (de baixo nível) que são suas realizadoras, uma vez que pode haver infinitas propriedades B capazes de realizar a propriedade A. Pode haver inúmeras misturas de inúmeras substâncias diferentes entre si capazes de dotar uma tela das mesmas propriedades macroscopicamente qualitativas de Uma visão de Toledo. Além disso, propriedades A e B costumam pertencer a níveis de descrição da realidade -distintos modo de classificar e organizar explicações dos fenômenos. As propriedades qualitativas da cópia fazem parte do repertório discursivo do crítico de arte e mesmo do leigo. As propriedades físico-químicas, por outro lado, fazem parte do jargão "científico" (na falta de uma palavra melhor). O discurso sobre propriedades A serve aos propósitos do crítico de arte - enquanto o discurso sobre propriedades B serve aos propósitos do perito técnico-científico que descobre a fraude perscrutando a estrutura físico-química da cópia.

No que tange especificamente à nossa questão, a ideia é então afirmar que o domínio normativo é superveniente ao domínio natural. Compromissos, status deônticos e regras são supervenientes a uma série de estados e propriedades (comportamentais, neurofisiológicas etc.) envolvendo os sujeitos engajados nas práticas normativas. Tal ideia encontra suporte textual no próprio Brandom, quando este declara que “(...) moldados no vocabulário da superveniência (grifo nosso), estabelecer todos os fatos especificáveis em vocabulário não-normativo estabelece todos os fatos especificáveis em vocabulário normativo (...)” (1994, p. 47). E esse uso do conceito de superveniência para integrar o normativismo forte do inferencialismo com o naturalismo é de fato algo muito próximo do que fizeram os filósofos da mente. Pois lembremos que o jargão técnico inferencialista brandominiano é aproximadamente equivalente aos nomes dos estados mentais intencionais da linguagem cotidiana. Compromissos são pensamentos; compromissos doxásticos, em particular, são crenças.

Podemos ver como o normativo sobrevém ao não-normativo usando novamente o jogo das fichas coloridas. Suponhamos que, em um dado momento de uma partida (em sua versão padrão), $\mathrm{C}$ tenha em seu painel um círculo vermelho e outro amarelo. Isso significa que na próxima rodada ele terá de afixar um círculo laranja em seu painel, uma vez que há uma regra no jogo que determina que, se um jogador possui um círculo vermelho e um amarelo em seu painel, então ele deve em seguida possuir também um laranja (“jogar laranja”). Vamos supor que $\mathrm{C}$ realmente 
jogue laranja na rodada seguinte, e consideremos então esta ação.

A ação "C jogar laranja na rodada $n$ " tem tanto propriedades normativas quanto não-normativas. Uma propriedade normativa distintiva é que ela é obrigatória em função da plêiade de status deônticos que constituem a pontuação deôntica que $\mathrm{C}$ possui (bem como das regras do jogo). Já uma propriedade nãonormativa dessa mesma ação é ela ter sido causada por uma plêiade fatos destacadamente $\mathrm{C}$ ter jogado vermelho e amarelo anteriormente, e $\mathrm{C}$ ter sido eficientemente treinado a jogar laranja se ele tiver jogado vermelho e amarelo anteriormente.

É concebível que $\mathrm{C}$ fosse obrigado a jogar laranja ainda que a ação de $\mathrm{C}$ de jogar laranja não tivesse sido causada desse modo. De fato, $\mathrm{C}$ poderia nem sequer ter jogado laranja em seguida - vamos supor que ele tivesse se distraído - mas ele permaneceria obrigado a jogar $\mathrm{C}$ pelo fato de a sua pontuação deôntica assim determinar. Por outro lado, se C não fosse obrigado a jogar laranja, então necessariamente pelo menos algumas propriedades não-normativas dessa ação teriam de ser diferentes. Talvez $\mathrm{C}$ não tivesse afixado em seu painel um círculo amarelo e outro vermelho; ou C não fosse obrigado por simplesmente não ter jamais participado do jogo; ou mesmo, talvez nunca tivesse havido no passado sujeitos se comportando de um tal modo que esse jogo fosse instituído com essas regras. Mesmo que a ação de $\mathrm{C}$ viesse a ocorrer sem que ele tivesse a obrigação de realizála, é certo que ela não teria exatamente as mesmas causas que ela teria na situação oposta.

Agora, uma vez que uma prática envolve necessariamente linguagem - se não a dos sujeitos da prática, ao menos a dos sujeitos que interpretam aqueles objetos como sendo sujeitos de uma prática - segue-se que a normatividade sobrevém ao surgimento da linguagem. Mais precisamente, a normatividade sobrevém ao desenvolvimento de uma linguagem expressivamente completa - isto é, com um vocabulário lógico (no sentido amplo de "lógico") adequado para a descrição do próprio domínio normativo.

Uma das vantagens da teoria da prática normativa de Brandom é que ela nos permite acomodar nossas intuições pré-teóricas de que pensamentos (compromissos doxásticos ou práticos) funcionam tanto como causas quanto como razões sem assimilar uma coisa à outra. Isso é possível precisamente porque, destacamos anteriormente, o discurso sobre compromissos possui tanto uma 
dimensão normativa quanto empírica.

A crença do meu vizinho de que o lixeiro passará em breve e o seu desejo de livrar-se do lixo (juntamente com uma plêiade de fatos) é a causa de ele colocar o lixo para fora para ser recolhido em sua calçada. Ao tomarmos os pensamentos no seu sentido empírico, tratamo-los mais ou menos do mesmo modo que eles são tratados pela ortodoxia funcionalista na filosofia da mente. Ter a crença de o lixeiro passará em breve é realmente uma questão de possuir outputs (comportamentais "externos" e mentais "internos") em função de inputs sensoriais interagindo com uma ampla gama de outros estados mentais. Mas a crença do meu vizinho de que o lixeiro passará em breve é também a justificativa para ele colocar o lixo para fora; é a justificativa porque é responsável pela sua habilitação para a ação de colocar o lixo para fora, de acordo com a sua pontuação deôntica - objetivamente determinada -naquele momento.

Notemos ainda que Brandom sustenta haver uma diferença de natureza entre compromissos no sentido empírico e compromissos no sentido normativo. Compromissos no sentido empírico são sempre compromissos que estão sendo assumidos ou atribuídos por sujeitos. São as fichas que, no jogo das fichas coloridas, são efetivamente jogadas pelos jogadores - quer no seu próprio painel ou nas tabuletas que registram a pontuação dos demais jogadores. ${ }^{84}$ Por outro lado, compromissos no sentido normativo são objetivos, e podem transcender as reais atitudes dos jogadores. Essa diferença leva Brandom a afirmar que, ao contrário das atitudes deônticas, status deônticos (e, por consequência, regras), não possuem nenhum poder causal:

Qualquer efeito que tais elementos da pontuação tenham sobre quais performances são realmente produzidas é indireto, mediado pelas atitudes daqueles que registram os pontos (keep score). A pontuação determina somente o que deveria (ought to) ser feito, o que seria adequado (proper). O que deveria ser feito e o que é adequado afetam o que os jogadores fazem apenas na medida em que eles são treinados a responder de vários modos a considerar um certo curso de ação como sendo adequado. O único acesso que status deônticos têm à ordem causal é através das atitudes deônticas dos membros da prática de registro de pontos. (1994, p. 260)

Esse contraste entre os status deônticos e as atitudes deônticas, e entre os sentidos normativo e empírico de compromissos/pensamentos é congruente com

\footnotetext{
${ }^{84}$ Obviamente, há um sentido mais fraco de normativo no qual aquilo que estamos chamando de "compromissos no sentido empírico" são também normativos. Eles seriam normativos em um grau porque eles só existem enquanto inseridos numa prática normativa, cuja correção é objetivamente determinada por suas regras.
} 
outro contraste aventado em 4.3.2, a saber, entre as relações inferenciais e o ato (psicológico) de inferir:

Relações inferenciais entre conteúdos proposicionais são uma questão de relações normativas entre status deônticos: compromisso com a alegação de que leões são mamíferos implica o compromisso com a alegação de que leões são vertebrados. Inferir, por contrate é um processo causal que relaciona atitudes deônticas: reconhecer (e igualmente, atribuir a alguém) compromisso com a alegação de que leões são mamíferos vai, sob várias circunstâncias e naqueles praticamente bem versados nas relações inferenciais entre status deônticos, tendo como uma consequência causal o reconhecimento (ou, correspondentemente, a atribuição) do compromisso com a alegação de que leões são vertebrados. A menos que os membros da comunidade linguística sejam muito bons em registrar pontos ao alterar suas atitudes como eles devem de acordo com os conteúdos associados aos status deônticos em termos dos quais eles registram pontos, não há sentido (point) em interpretá-los como se engajando em práticas especificadas por aquelas adequações do registro de pontos. (1994, p. 260)

O domínio do puramente normativo é assim um produto de um complexo de comportamentos de seres sapientes. Status deônticos e regras - que constituem os compromissos no sentido normativo e as suas relações inferenciais - seriam epifenômenos, para usar uma expressão própria dos filósofos da mente. Embora conectados com o mundo natural por serem instituídos por atitudes deônticas, eles por si mesmos não têm nenhuma influência causal sobre a conduta dos sujeitos.

\subsection{A lógica de "querer dizer"}

Em 3.1 elencamos uma série de enunciados que compõem o que chamamos de discurso semântico, e perguntamos acerca da sua forma lógica:

(6) "Rouge" quer dizer / significa vermelho em francês';

(7) "Solteiro" e "não casado" são sinônimos;

(8) Joana se referiu ao último filme que assistiu;

(9) A crença de Roberto era sobre coelhos;

"Vênus e Saturno são planetas visíveis a olho nu" é um enunciado verdadeiro.

Vimos no capítulo anterior como expressões referenciais de re ("ser sobre", “de”, “do") e veritativas, assim como doxásticas, são expressivamente deduzidas. Desse modo, já esboçamos qual seria a forma lógica dos últimos três enunciados da lista acima. Vimos também o lugar do vocabulário normativo na semântica inferencialista.

Agora, ficou faltando, entretanto, uma explicação a respeito do vocabulário sobre significação linguística com a qual o problema de seguir uma regra é canonicamente formulado: querer dizer e significar. Uma vez que o inferencialismo 
inverte a ordem explicativa tradicional a respeito do vocabulário semântico, do qual "querer dizer" e "significar" são espécies, tais operadores não devem ser vistos como representando "terminais" onde mente e realidade se conectam diretamente, mas como conceitualmente posteriores a praticamente todo o vocabulário intencional restante.

Essa tarefa de elucidar a forma lógica de "querer dizer" não é nem indiretamente realizada por Brandom, quer em Making it Explicity ou qualquer outra obra sua de grande envergadura. Curiosamente, foi Sellars - predecessor de Brandom - quem, já em meados da década de 1950, se encarregou de tal trabalho. A análise de Sellars se concentra não nos usos de querer dizer / significar focados em um sujeito, como na formulação kripkeana do problema de seguir uma regra, mas precisamente nos usos de querer dizer / significar como em (1) e (2). Seu principal insight é que, em enunciados como

(1) "Rouge" significa vermelho em francês;

a palavra "vermelho" não está nem sendo mencionada nem usada. Não está sendo utilizada porque em tal enunciado não se está atribuindo ou negando a propriedade de ser vermelho a nada. Mas ela também não está sendo mencionada, ou ao menos não mencionada como uma palavra costuma ser. Se nós traduzíssemos o enunciado para o inglês, nós traduziríamos "vermelho" para o inglês também, mas não a palavra "rouge", que está genuinamente sendo mencionada:

(1') "Rouge" means red in French.

Não sendo nem usada nem mencionada, Sellars diria que nesse caso, a palavra "vermelho" aparece como um sortal ilustrativo interlinguístico. Um sortal ilustrativo interlinguístico pega um uso específico de uma expressão linguística e a utiliza como exemplar de um conjunto de expressões que possuem aquele mesmo papel funcional, quer na língua própria da qual a expressão ocorre, quer em outras línguas onde haja uma expressão com papel funcional equivalente. Sellars introduz uma notação própria para capturar o papel funcional da expressão em questão: as aspas-ponto (dot quote). Assim, (1) seria parafraseada como 
$\left(1^{\prime \prime}\right)$ "Rouge" quer dizer/ significa •vermelho• em francês;

onde a expressão entre as aspas-ponto está no mesmo idioma que é utilizado como mentalinguagem - no caso, o português.

Em função do seu compromisso com o nominalismo, a análise de Sellars resulta em uma série de complicações idiossincráticas para garantir que nenhuma alusão a entidades abstratas seja feita "oficialmente" (cf. SELLARS, 2007, pp.9397). Embora seja inegável que o tipo de investigação proposta nesse trabalho tenha desdobramentos ontológicos, adentrar a fundo em considerações ontológicas nos deixaria bastante ocupados e nos levaria para muito longe do escopo deste trabalho, vamos omitir muitos dos detalhes da explicação sellarsiana. ${ }^{85}$

O que é relevante aqui é que se considerarmos todo o maquinário teórico que Brandom colocou à nossa disposição, podemos com segurança identificar aquilo que é individualizado pelas aspas-ponto justamente com o papel inferencial de uma expressão subsentencial, ou com o potencial inferencial de um enunciado se a expressão em questão for um enunciado - do ponto de vista do sujeito que utiliza o operador de significação. Quando consideramos a forma canônica geral de uma atribuição de significação

$$
s \text { quer dizer } m \text { por } e(\mathrm{em} \mathrm{t})
$$

estabelecemos assim que a expressão a assumir o valor de $m$ não é meramente uma expressão utilizada na linguagem na qual atribuição é feita (a metalinguagem), mas o papel inferencial associado a ela, que é capturado por essa expressão entre as aspas-ponto. Ainda mais importante, a identificação de $m$ como o papel inferencial de $e$ nos permite compreender o que estamos fazendo quando utilizamos uma atribuição de significação, pois é nisso que consiste genuinamente a sua forma lógica.

A ideia aqui é que uma tal atribuição de significação consiste em duas coisas. Em primeiro lugar, estamos atribuindo ao sujeito um conjunto de status deônticos (compromissos, habilitações e preclusões a compromissos) implicados

\footnotetext{
${ }^{85}$ De qualquer modo, se não formos nominalistas, então nosso tipo de realismo sobre entidades abstratas deveria ser muito mais fraco do que os tipos mais tradicionais de realismo defendidos nessa seara. Isso porque nenhuma propriedade ou qualquer outra entidade abstrata seriam "independentes da mente", no sentido de que elas não poderiam existir sem que fosse produto da atividade cognitiva de seres sapientes. Assim, o realismo dos abstracta compatível com o inferencialismo seria mais próximo do que tradicionalmente se chamou de conceitualismo.
} 
pela posse do conceito de $m$ a tal sujeito. Em segundo lugar, estamos atrelando esse conjunto de status deônticos relativos ao conceito de $m$ ao (tipo de) signo que está sendo mencionado; no caso limítrofe, quando o tipo canonicamente mencionado aparece também entre as aspas-ponto, estamos considerando que os usos que o sujeito alvo da nossa atribuição faz daquele signo é governado pelo mesmo conjunto de status deônticos que o uso que nós fazemos daquele mesmo signo.

Voltando ao exemplo que WK dá ao formular o problema de seguir uma regra, quando dizemos "João quer dizer + por '+"” estamos dizendo que (i) João possui o conceito de adição, o que envolve a atribuição a João da plêiade de status deônticos que constitui o conceito, incluindo, por exemplo, o compromisso de alcançar o resultado real de uma soma todas as vezes que assumir o compromisso de efetuar tal operação; e (ii) os usos que João faz do signo "+" têm sua correção ou incorreção em última análise determinadas pelo conceito de adição, ao qual ele está atrelado.

E quanto aos enunciados de sinonímia como (1) e (2), que, como vimos, eram os objetos mais imediatos do escrutínio teórico de Sellars? Complicações a respeito do próprio conceito de sinonímia a parte, também não é difícil ver como o tratamento a partir da forma canônica geral de uma atribuição de significação deveria ser estendido para cobrir tais casos. $\mathrm{O}$ vocabulário de um idioma consiste basicamente na associação entre status deônticos e tipos de signos. Assim, podemos compreender esses enunciados como estabelecendo uma correlação entre padrões de associação entre status deônticos e tipos de signos. 


\section{Conclusão}

A nossa proposta de encontrar uma solução inferencialista para o problema de seguir uma regra pode ser recapitulada de modo resumido da seguinte maneira.

O capítulo 2 cumpriu a função de justificar a importância da filosofia da linguagem - em especial da semântica - para a filosofia como um todo. Assim, fica previamente motivada a relevância do problema de seguir uma regra e as discussões envolvendo o inferencialismo. Uma teoria do significado permite discutirmos no seu bojo e de forma ordenada e sistemática, questões metafísicas e epistemológicas. Em especial, firmamos em tal capítulo nossa posição em dois pontos: (i) nossa preferência por uma forma viável de realismo, que não fosse presa fácil para o ceticismo - o que se traduziu na chamada independência do juízo do valor de verdade dos enunciados; e (ii) nossa antipatia pelo representacionismo - em conexão com (i) e com o argumento da manifestação - motivando assim a busca por uma estratégia alternativa na elaboração de uma teoria do significado.

No capítulo 3, alcançamos uma compreensão clara do problema de seguir uma regra utilizando a engenhosa reconstrução do argumento cético de WK feita por Hattiangadi. A ideia é que, por trás de virtualmente todas as teorias que tentaram responder à questão fundacional do significado ("Em virtude de quais fatos um sujeito quer dizer $m$ pela expressão $e$ ?") estariam três teses, cada qual gozando de um extremo apelo intuitivo: o realismo semântico, o normativismo e o internalismo motivacional.

O realismo semântico é entendido como uma especificação da marca do realismo independência do juízo na seara da semântica. Ele sustenta que um fato constitutivo do significado de uma expressão $e$ determina de antemão quais os usos possíveis e futuros de $e$ por um sujeito (ou comunidade de sujeitos) são corretos e quais são incorretos, independentemente de como os usuários venham a julgar concretamente tais usos. O normativismo envolve o compromisso com a tese de 
que o significado linguístico é normativo em um sentido forte. Uma vez que um dado sujeito quer dizer $e$ por $x$, ele possui obrigações semânticas de usar ou não usar a expressão $e$ de acordo com as condições de correção estabelecidas pelos relativos fatos constitutivos do significado de $e$. Já o internalismo motivacional seria a ideia de que, se o sujeito julga que deve fazer algo em uma determinada condição (no caso, julga que ele deve, pode ou não pode usar a expressão $e$ ), então ele possui uma motivação para fazer tal coisa.

O cético semântico teria argumentado então que as três teses formariam uma tríade inconsistente: quando elas são postas juntas para explicar a fundação da significação linguística, elas acabariam nos colocando diante de um dilema insolúvel. Ou bem caímos em uma falácia naturalista, de tentar reduzir obrigações ou deveres a estados de coisas desprovidos de qualquer carga normativa; ou bem cairíamos na extravagância metafísica de afirmar que fatos normativos não naturais tem poderes causais. Considerando que o dilema é insolúvel, não haveria como evitar a conclusão cética.

Ocorre que, como também mostramos no capítulo 3, a conclusão cética de que não há fatos constitutivos do significado é autorrefutada e, portanto, insustentável. Pois, para que a conclusão cética possa ser verdadeira, como ela pretende ser, ela precisa que as expressões nela envolvidas sejam significativas. No entanto, pelo seu próprio conteúdo, ela implica não só que ela não é verdadeira, mas que ela é literalmente sem sentido. Tal situação nos levaria a ter de rejeitar, assim, pelo menos uma daquelas três teses. Argumentamos, em seguida, que renunciar ao realismo ou ao normativismo não nos deixaria em melhor situação para enfrentar o cético. Nossa posição ali foi então adotar uma versão reformulada do internalismo motivacional, que estivesse mais afinada com o normativismo. Motivos devem ser entendidos mais como razões do que como causas: ter um motivo para fazer algo não deve ser equivalente (embora possa e deve de alguma forma envolver) estar propenso a fazer algo.

Os últimos dois capítulos, 4 e 5, trazem finalmente o inferencialismo para o debate.

O capítulo 4 apresenta e explora o maquinário teórico-conceitual do inferencialismo de Pittsburgh. No seu fundamento está o normativismo pragmático, a ideia de que os elementos básicos de uma teoria semântica se encontram em uma teoria da prática normativa. Uma prática normativa é constituída por sujeitos cujas 
performances são consideradas corretas ou incorretas de acordo com os status deônticos que eles possuem. Esses status deônticos são definidos em termos de compromissos em realizar certas performances, e em habilitações de preclusões desses compromissos. Asserções são então definidas como consistindo em performances envolvendo o uso de tipos que os sujeitos usam para atribuir a si próprios compromissos de uma espécie especial: compromissos com conteúdo intencional. A individualização do conteúdo intencional de uma asserção é feita partindo das relações de implicação, compatibilidade e incompatibilidade entre compromissos, o que constitui o potencial inferencial de uma sentença, passando pela introdução do vocabulário lógico proposicional e a dedução expressiva da forma lógica da linguagem (termo singular e predicado) até derivarmos termos próprios do discurso semântico, como ser sobre algo (um objeto) e verdade.

No capítulo 5, desenvolvemos uma teoria fundacional do significado de estirpe inferencialista, não perdendo de vista o enfrentamento ao ceticismo semântico. Ali, sustentamos que os status deônticos são constituídos pelas atitudes deônticas que os sujeitos de uma prática discursiva assumem uns em relação aos outros. Isso não quer dizer, entretanto, que os fatos semânticos - dado pelo conjunto de status deônticos dos sujeitos - sejam redutíveis ao conjunto de atitudes deônticas que os sujeitos de fato mantêm ao longo do tempo. O inferencialismo resta assim comprometido com o realismo semântico.

Essa posição do inferencialismo - que combina realismo, normativismo e uma versão de internalismo motivacional - ainda teria pendente sobre si uma acusação por parte do cético. O inferencialista seria aqui acusado de desaguar em uma metafísica extravagante. A nossa resposta foi então explorar a noção de superveniência. Alterações em estados de coisas normativos - como a alteração no placar deôntico de um sujeito - implica alterações em estado de coisas não normativos - embora o contrário não seja procedente. Os membros de uma prática discursiva são habitantes do domínio normativo, mas não são feitos de nada além daquilo que compõe o mundo natural, não normativo. Fatos normativos são supervenientes aos fatos naturais; os primeiros não existiriam senão houvesse os últimos.

Ao fecharmos o capítulo 5, buscamos uma explicação inferencialista para os enunciados de atribuições de significado - "s quer dizer $m$ por $e$ ". Em termos do modelo de registro de pontos de Brandom, o uso de tais enunciados consiste em 
duas coisas: primeiro, atribuir ao sujeito em questão a posse do conceito de $m$, o que equivale a atribuir a ele um conjunto de status deônticos que constituem o referido conceito; e segundo, atrelar a correção ou incorreção dos usos que o sujeito atribuído faz de $e$ ao conceito de $m$. 


\section{Referências bibliográficas}

AYER, A. J. Language, Truth and Logic. Nova lorque: Dover Books, 1952.

BAKER, G.P. \& HACKER, P.M.S. Scepticism, Rules and Language. Oxford: Basil Blackwell, 1984.

BOGHOSSIAN, P. "Naturalizing content". In: LOEWER, B. \& REY, G. (editores). Meaning in Mind: Fodor and his Critics. Oxford: Blackwell Publishers, 1991.

."The Rule-Following Considerations". In: MILLER, A. \& WRIGHT, C. (editores) Rule-Following and Meaning. Chesham: Acumen, 2002.

BRANDOM, R. Making it Explicit: Reasoning, Representing, and discursive commitment. Cambridge, Massachusetts: Harvard University Press, 1994.

Articulating Reasons: an introduction to inferentialism. Cambridge, Massachusetts: Harvard University Press, 2001.

BURGUESS, A. \& SHERMAN. B.. "Introduction: A Plea for the Metaphysics of Meaning" In: BURGUESS, A. \& SHERMAN, B. (editores). Metasemantics. Oxford: Oxford University Press, 2014.

COPI, I. Introdução à lógica. Tradução: Álvaro Cabral. São Paulo: Editora Mestre Jou, 1978.

DAVIDSON, D. Inquires into Truth and Interpretation. Nova lorque: Oxford University Press, 1984.

DENNETT, D. Brainstorms: Philosophical Essays on Mind and Psychology. Cambridge, Massachusetts: The MIT Press, 1981. 
DEVRIES, W. Wilfrid Sellars. Chesham: Acumen, 2005.

DUMMETT, M. 'What is a Theory of Meaning? (II)'. In: EVANS, G. \& MCDOWELL, J. (editores). Truth and Meaning: Essays in Semantics. 2a edição. Nova lorque e Oxford: Oxford University Press, 2005.

Truth and Other Enigmas. Cambridge, Massachusetts:

Harvard University Press, 1078.

FREGE, G. Lógica e Filosofia da Linguagem. Seleção, tradução, introdução e notas: Paulo Alcoforado. Edição revisada. São Paulo: Edusp, 2009.

. "Thought". In: The Frege Reader. Edição: Michael Beaney. Oxford: Blackwell Publishing, 1997.

GLÜER, K. \& WIKFORSS, A. "The Normativity of Meaning and Content". In: ZALTA, E. N. (ed.) The Stanford Encyclopedia of Philosophy, 2020. $\mathrm{URL}=$ https://plato.stanford.edu/entries/meaning-normativity/>

GUIRLE, R. Modal Logics and Philosophy. $2^{\mathrm{a}}$ edição. Durham: Acumen, 2009.

HATTIANGADI, A. Oughts and Thougts: Rule-Following and the Normativity of Content. Oxford: Oxford Universty Press, 2007.

HUTTO, D. \& SATNE, G.. "Naturalism in the Goldlocks Zone: Wittgenstein's Delicate Balacing Act." In: CAHILL, K. \& RALEIGH, T. (editores). Wittgenstein and Naturalism. Londres e Nova lorque: Routledge, 2018.

KANT, I. Fondements de la Metaphysique des Moeurs. Tradução: Victor Delbos. Paris: Librarie Générale Française, 1993.

KENNY, A. Wittgenstein. Edição revisada. Oxford: Blackwell Publishing, 2006.

KIRKHAM, R. Teorias da Verdade: Uma Introdução Crítica. Tradução: Alessandro Zir. São Leopoldo: Editora Unisinos, 2003.

KRIPKE, S. Naming and Necessity. Cambridge (Massachussetts): Harvard University Press, 1980.

Massachusetts: Harvard University Press, 1982.

Wittgenstein on Rules and Private Language. Cambridge, 
$\mathrm{KUSCH}, \mathrm{M}$. A Sceptical Guide to Meaning and Rules. Chesham: Acumen, 2006.

LOUX, M. Metaphysics: a Contemporary Introduction. $3^{a}$ edição. Londres e Nova lorque: Routledge, 2006.

LYCAN, W. Philosophy of Language: A Contemporary Introduction. Londres e Nova lorque: Routledge, 2000.

MCARTHUR, D. "Wittgenstein's Liberal Naturalism on Human Nature". In: CAHILL, K. \& RALEIGH, T. (editores). Wittgenstein and Naturalism. Londres e Nova lorque: Routledge, 2018.

MCDOWELL, J. Mind, Value and Reality. Cambridge, Massachusetts: Harvard University Press, 1998.

MCGINN, C. Wittgenstein on Meaning. Oxford: Basil Blackwell, 1984.

MCLAUGHLIN, B. "Varieties of Supervenience". In: SAVELLOS, E. \& YALCIN, U. (editores). Supervenience: New Essays. Cambridge: Cambridge University Press, 1995. "Supervenience". In: ZALTA, E. N. (ed.) The Stanford

Encyclopedia of Philosophy, 2021. URL =
<https://plato.stanford.edu/entries/supervenience/>

MILLER, A. Philosophy of language. $2^{\mathrm{a}}$ edição. Londres e Nova lorque: Routledge, 2007.

MOORE, G.E. Some Main Problems of Philosophy. Londres e Nova lorque: George Allen \& Unwin Ltd, The MacMillan Company, 1953.

MORTARI, C. A. Introdução à Lógica. São Paulo: Editora UNESP, 2001.

NEY, A. Metaphysics: An Introduction. Nova lorque: Routledge, 2014.

PAPINEAU, D. "Naturalism". In: ZALTA, E. N. (ed.) The Stanford Encyclopedia of Philosophy, 2020. URL = <https://plato.stanford.edu/entries/naturalism/>

PENCO, C. Introdução à Filosofia da Linguagem. Tradução: Ephraim F. Alves. Petrópolis: Vozes, 2006. 
PEREGRIN, J. Inferentialism: Why Rules Matter. Nova lorque: Palgrave McMillan, 2014.

PUTNAM, H. Mind, Language and Reality: Philosophical Papers, Vol. 2. Cambridge: Cambridge University Press, 1975.

QUINE, W. V. O.. Palavra e Objeto. Tradução: Sofia Inez Albornoz Stein \& Desidério Murcho. Revisão técnica: Sofia Inez Albornoz Stein. Petrópolis: Vozes, 2010.

De um Ponto de Vista Lógico. Tradução: Antonio lani Segatto. São Paulo: Editora Unesp, 2011.

RUSSELL, B. Problems of Philosophy. $2^{\mathrm{a}}$ edição. Introdução: John Skorupstki. Oxford: Oxford University Press, 1998. . Introdução à Filosofia Matemática. Tradução: Maria Luiza X. de A. Borges. Revisão técnica: Samuel Jurkiewicz. Rio de Janeiro: Zahar, 2007.

. Principles of Mathematics. Introdução: John G. Slater. Londres e Nova lorque: Routledge, 2010.

SELLARS, W. Empirismo e Filosofia da Mente. Tradução: Sofia I. A. Stein. Petrópolis: Vozes, 2005.

In the Space of Reasons: Selected Essays of Wilfrid Sellars. Edição: Kevin Scharp e Robert Brandom. Cambridge, Massachusetts: Harvard University Press. 2007

SPEAKS, J. 'Theories of Meaning'. In: ZALTA, E. N. (ed.) The Stanford Encyclopedia of Philosophy, $2020 . \quad$ URL= $<$ https://plato.stanford.edu/entries/meaning/>

STAINTON, R. Words and Thoughts: Subsentences, Ellipsis and the Philosophy of Language. Oxford: Oxford University Press, 2006.

STRAWSON, P. F. Análise e Metafísica: Uma Introdução à Filosofia. Tradução: Armando Mora de Oliveira. São Paulo: Discurso Editorial, 2002.

WHITING, D. "Is meaning fraught with ought?". In: Pacific Philosophical Quarterly, 90: 535-555, 2009. 
WILLIAMSON, T. The Philosophy of Philosophy. Oxford: Blackwell Publishing, 2007.

WITTGENSTEIN, L. Tractatus Logico-Philosophicus. Tradução: Luiz Henrique Lopes dos Santos. 3a edição. São Paulo: EDUSP, 2020.

Observações Filosóficas. Tradução: Adail Sobral e Maria Stella Gonçalves. São Paulo: Edições Loyola, 2005.

Philosophical Investigations. Tradução: G.E.M Anscombe, Joachim Schulte e P.M.S. Hacker. 4a Edição. Oxford: WileyBlackwell, 2009.

WRIGHT, C. Realism, Meaning and Truth. 2a edição. Oxford: Blackwell, 1993.

University Press, 1992

. Truth and Objectivity. Cambridge, Massachussetts: Havard

"Meaning and Intention as Judgement Dependent" In: MILLER, A. \& WRIGHT, C. (editores) Rule-Following and Meaning. Chesham: Acumen, 2002.

Rails to Infinity: Essays on Themes from Philosophical Investigations. Cambridge, Massachussetts: Harvard University Press, 2001.

YALCIN, S. "Semantic as Model Basic Science". In: BALL, D. \& RABERN, B. (editores). The Science of Meaning. Oxford: Oxoford University Press, 2018. 


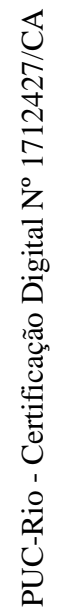

